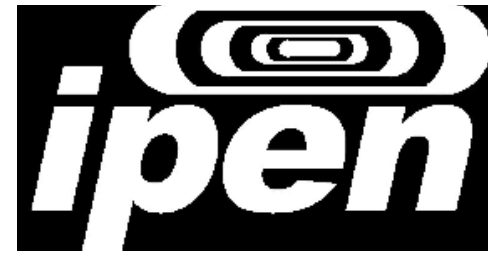

AUTARQUIA ASSOCIADA À UNIVERSIDADE DE SÃO PAULO

\title{
BIODEGRADAÇÃO DE REJEITOS RADIOA TIVOS LÍQUIDOS ORGÂNICOS PROVENIENTES DO REPROCESSAMENTO DO COMBUSTÍVEL NUCLEAR
}

RAFAEL VICENTE DE PÁDUA FERREIRA

Dissertação apresentada como parte dos requisitos para obtenção do Grau de Mestre em Ciências na Área de Tecnologia Nuclear Aplicações

Orientador:

Dra. Maria Helena Bellini 
"Não há qualquer campo do saber humano, seja na indústria, na agricultura, no preparo de alimentos, em conexão com problemas de habitação ou de vestuário, na conservação da saúde humana ou de animais e no combate às doenças, em que o micróbio não desempenhe um papel importante e, às vezes, dominante"

"Trecho do discurso presidencial à sociedade de bacteriologistas Norte-americanos (1942), Proferido por Selman A. Waksman" (PELCZAR, 1980) 
Aos meus pais 


\section{Agradecimentos}

À Profa. Dra. Maria Helena Bellini, pela oportunidade de tê-la como orientadora, pela amizade e oportunidades que me proporcionaram crescimento profissional.

Ao Dr. Júlio Takehiro Marumo, por sempre ter acreditado no meu trabalho, pela paciência, apoio, conselhos e orientação. Muito obrigado !!

À Dra Solange Sakata, pelo auxilio, sugestões e discussões.

Aos Drs Fernando Dutra e Patrícia Busko Di Vitta, por abrirem as portas de seus laboratórios.

Aos colegas do Laboratório de Rejeitos Radioativos, pelo auxílio, apoio e incentivo.

Ao Instituto de Pesquisas Energéticas e Nucleares por tornarem possível a realização deste trabalho por meio da concessão de bolsa de estudo. 


\title{
BIODEGRADAÇÃO DE REJEITOS RADIOATIVOS LÍQUIDOS ORGÂNICOS PROVENIENTES DO REPROCESSAMENTO DO COMBUSTÍVEL NUCLEAR
}

\author{
Rafael Vicente de Pádua Ferrei ra
}

\begin{abstract}
RESUMO
O reprocessamento do elemento combustível constitui uma das etapas do ciclo do combustível e tem por objetivo separar $\mathrm{U}^{235}, \mathrm{U}^{238}$ e $\mathrm{Pu}^{239}$ dos produtos de fissão contidos no elemento combustível queimado para reutilizá -los na fabricação de novos elementos combustíveis. No Brasil, o desenvolvimento do reprocessamento teve início nos anos $70 \mathrm{com}$ a implantação de uma planta piloto de reprocessamento, no Instituto de Pesquisas Energéticas e Nucleares - Comissão Nacional de Energia Nuclear/São Paulo (IPEN-CNEN/SP), dando origem à uma instalação, em escala de laboratório, que operou até o início da década de 90. Parte dos rejeitos radioativos, produzidos principalmente a partir dos laboratórios analíticos está armazenados à espera de tratamento no Labora tório de Gestão de Rejeitos do IPEN-CNEN/SP, e são constituído pela mistura de fases aquosa e orgânica. Por conter compostos orgânicos, esses rejeitos não podem se solidificados diretamente com cimento, necessitando para isso, de tratamento prévio para torná-los compatíveis. Desta forma, o objetivo deste trabalho foi desenvolver uma metodologia de biodegradação dos compostos orgânicos que compõem os rejeitos radioativos líquidos orgânicos (RRLO) para que os mesmos possam ser posteriormente imobilizados em c imento. $O$ trabalho foi dividido em três etapas, a de caracterização dos RRLO, obtenção das comunidades microbianas (da mina de urânio de Poços de Caldas e do estuário de São Sebastião) e realização de ensaios de biodegradação dos RRLO. A partir da caracterização dos rejeitos, a biodegradação do TBP e acetato de etila foram monitoradas. Os resultados mostraram que as comunidades bacterianas selecionadas foram eficientes para a degradação dos rejeitos radioativos líquidos orgânicos. Ao final dos experimentos os níveis biodegradação foram de $66 \%$ para o acetato de etila e $70 \%$ para o TBP.
\end{abstract}




\title{
BIODEGRADATION OF RADIOACTIVE ORGANIC LIQUID WASTE FROM SPENT FUEL REPROCESSING
}

\author{
Rafael Vicente de Pádua Ferreira
}

\begin{abstract}
The research and development program in reproces sing of low burn-up spent fuel elements began in Brazil in 70's, originating the lab -scale hot cell, known as CELESTE located at Nuclear and Energy Research Institute, IPEN - CNEN/SP. The program was ended at the beginning of 90's, and the laboratory was c losed down. Part of the radioactive waste generated mainly from the analytical laboratories is stored waiting for treatment at the Waste Management Laboratory, and it is constituted by mixture of aqueous and organic phases. The most widely used technique for the treatment of radioactive liquid wastes is the solidification in cement matrix, due to the low processing costs and compatibility with a wide variety of wastes. However, organics are generally incompatible with cement, interfering with the hydration and setting processes, and requiring pre-treatment with special additives to stabilize or destroy them. The objective of this work can be divided in three parts: i) organic compounds characterization in the radioactive liquid waste; ii) the occurrence of bacterial consortia from Poços de Caldas uranium mine soil and São Sebastião estuary sediments that are able to degrade organic compounds and third, the development of a methodology to biodegrade organic compounds from the radioactive liquid waste aiming th e cementation From the characterization analysis, TBP and ethyl acetate were chosen to be degrade $d$. The results showed that selected bacterial consortia were efficient for the organic liquid wastes degradation. At the end of the experiments the biodegradat ion level were $66 \%$ for ethyl acetate and $70 \%$ for the TBP.
\end{abstract}




\section{SUMÁRIO}

Página

1. INTRODUÇÃO

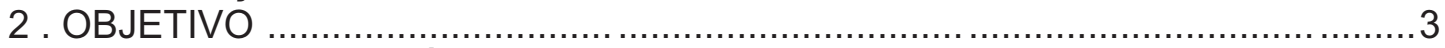

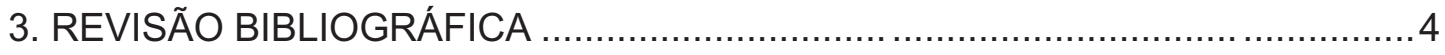

3.1. Gerência de rejeitos radioativos ........................................................ 4

3.2. Principais compostos orgânicos util izados no processo PUREX .................... 9

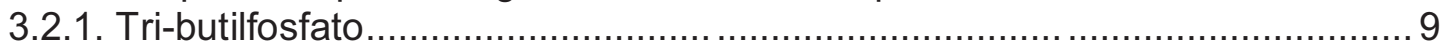

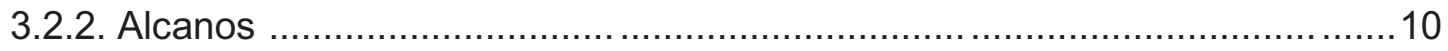

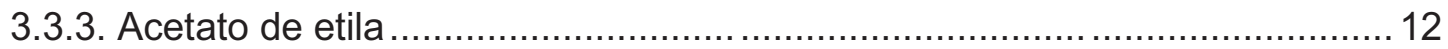

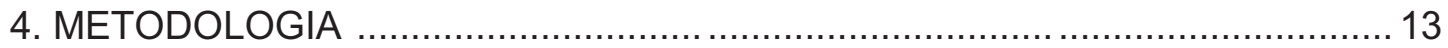

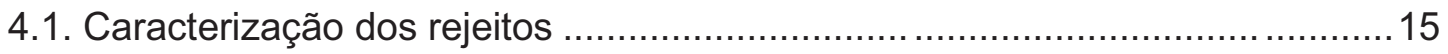

4.2. Obtenção e estudo das comunidades mi crobianas .................................... 17

4.2.1. Avaliação dos RRLO quanto à presença de microrganismos .................... 17

4.2.2. Ensaios de biodegradação dos principais compostos orgânicos presentes

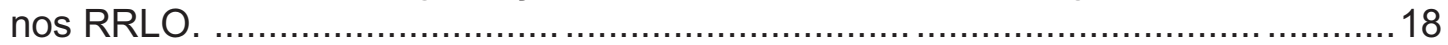

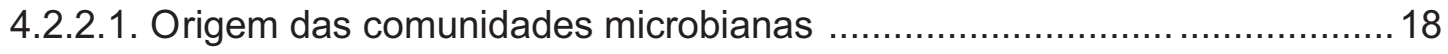

4.2.2.2. Obtenção das comunidades microbianas ........................................... 20

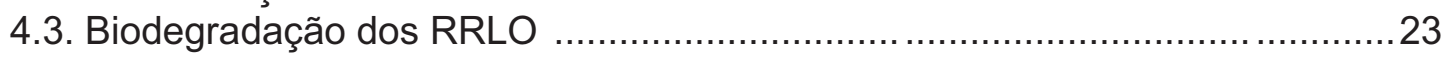

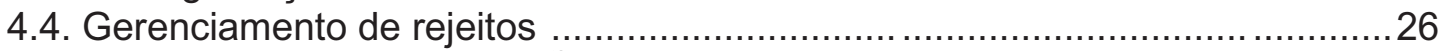

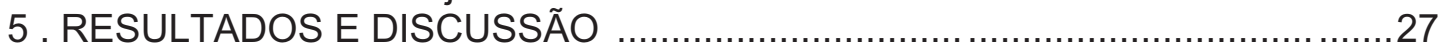

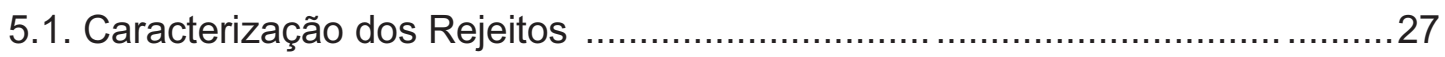

5.2. Obtenção e estudo das comunidades microbianas .................................29

5.2.1. Avaliação da contaminação por microrganismos. ..................................29

5.2.2. Determinação da concentração inibitória mínima (CIM) dos Rejeitos

Radioativos Líquidos Orgânicos (RRLO). ..................................................... 29

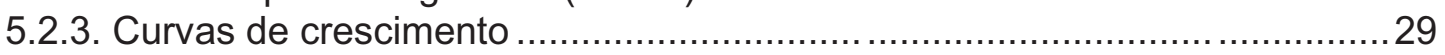

5.2.4. Experimentos de biodegrad ação dos compostos orgânicos presentes nos

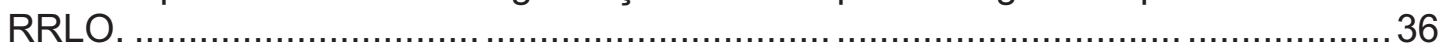

5.2.4.1. Biodegradação do acetato de etila ................................................. 36

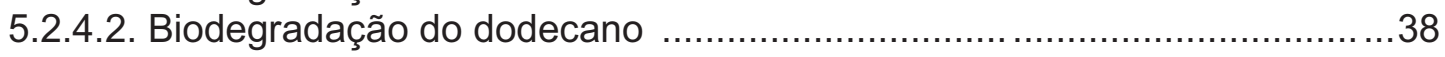

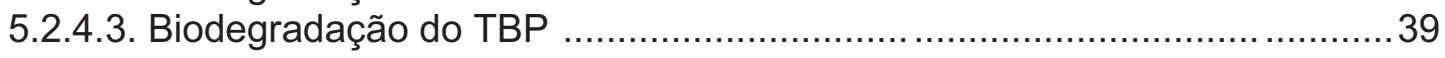

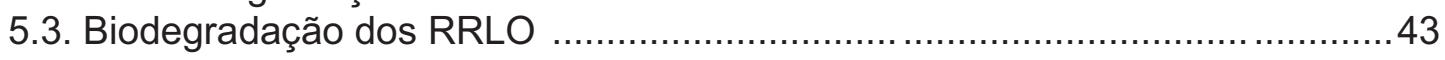

5.3.1. Concentração inibitória mínima (CIM) dos RRLO destilados ......................43

5.3.2. Ensaios de biodegradação dos RRLO 80 e 85 in natura e destilados. .......43

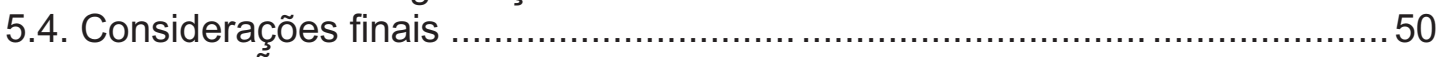

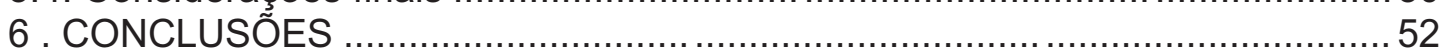

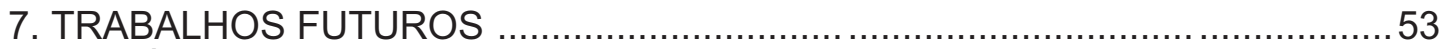

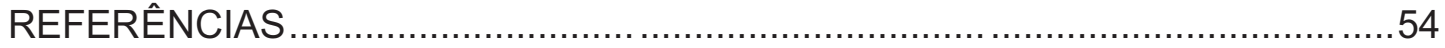




\section{INTRODUÇÃO}

A energia nuclear é mundialmente utilizada, não somente como fonte geradora de eletricidade, mas também para produção de radioisótopos, os quais têm sido amplamente utilizados na área agrícola, médica e, especialmente, em pesquisa. O custo para a sociedade, advindo da utilização dessas tecnologias , é a geração de rejeitos radioativos que, da mesma forma que os resíduos convencionais, devem ser tratados adequadamente para garantir a segurança do homem e do meio ambiente.

A Agência Internacional de Energia Atômica define rejeito radioativo como "material que contém ou que está contaminado com radionuclídeos em concentrações ou níveis de atividade maiores que os limites de isenção estabelecidos pela autoridade competente" (HIROMOTO et al,1999). No Brasil, a Comissão Nacional de Energia Nuclear define o rejeito radioativo como: "qualquer material resultante de atividades humanas, que contenha radionuclídeos em quantidades superiores aos limites de isenção especificados na Norma CNEN NE-6.05 - Gerência de Rejeitos Radioativos em Instalações Radioativas, e para o qual a reutilização é imprópria ou não prevista " (CNEN, 1985).

Antes de serem encaminhados para o armazenamento provisório ou a deposição final, todos os rejeitos radioativos devem ser tratados e acondicionados adequadamente e, em alguns casos, solidificados com materiais que variam de acordo com o tipo de rejeito. A imobilização tem como objetivo transformar o rejeito em uma forma estável para o armazenamento seguro e atender aos critérios de aceitação de embalagens em repositórios, sendo a cimentação, o processo mais empregado. Essa técnica, no entanto, apesar de ser simples e barata, tem limitações como baixa capacidade de carga para as resinas e incompatibilidade química com líquidos orgânicos (MESQUITA, 1980, IAEA, 2004).

A uma das principais fontes geradora de rejeitos radioativos líquidos orgânicos (RRLO) no Brasil foram as atividades de reprocessamento do combustível nuclear. O desenvolvimento do reprocessamento no Brasil teve iní cio nos anos 70 com a implantação do Projeto Reprocessamento, no Instituto de Pesquisas Energéticas e Nucleares - Comissão Nacional de Energia Nuclear/São Paulo (IPEN-CNEN/SP), dando origem à instalação, em escala de laboratório, 
CELESTE (CÉLula de Estudos e Testes de Extração). Esta instalação operou até o início da década de 90 utilizando o $1^{\circ}$ ciclo do processo com capacidade máxima de tratamento de $1 \mathrm{Kg}$ de metal pesado por campanha (FORBICINI, 1994).

O reprocessamento do elemento combustível constitui uma das etapas do ciclo do combustível e tem por objetivo separar U-235, U-238 e Pu-239 dos produtos de fissão contidos no elemento combustível queimado para reutilizá -los na fabricação de novos elementos combustíveis (HIROMOTO et al,1999).

Ao longo dos anos, vários processos foram desenvolvidos para se realizar o reprocessamento, utilizando-se de diferentes técnicas, sendo a extração com solventes a mais eficiente e segura nas operações em escala industrial. Dentre os processos de extração com solventes destaca-se o PUREX (Plutonium Uranium Recovery by Extracion). Neste processo o solvente utilizado é o tri-butil fosfato (TBP) diluído, geralmente, com hidrocarbonetos de cadeia longa como o dodecano ou misturas como querosene e varsol. O processo PUREX apresenta uma série de vantagens quando comparado com outros processos de extração incluindo menor volatilidade e flamabilidade do solvente, maior estabilidade química e resistência à radiação, além de apresentar um custo operacional mais baixo. Os RRLO são gerados principalmente durante este processo. (IAEA, 2004).

Em muitos países esses rejeitos são tratados por incineração, que destrói os compostos orgânicos perigosos sendo os radionuclídeos presentes capturados pelas cinzas voláteis ou liberados com os gases (IAEA, 1988). No Brasil, não há incineradores disponíveis para a queima de rejeitos radioativos e por isso o processo de tratamento utilizado é a sua incorporação em cimento .

O principal problema para a imobilização dos RRLO decorre da incompatibilidade química entre o rejeito e a matriz de imobilização (cimento), necessitando para isso, de tratamento prévio .

Diante deste problema a utilização de microrganismos para o tratamento dos RRLO armazenados no LRR-IPEN/CNEN-SP, surge como uma tecnologia bastante promissora. Esta abordagem baseia -se na utilização de microrganismos capazes de metabolizar os componentes orgânicos dos rejeitos tornando -os compatíveis com a matriz de cimento (IAEA, 2004). 


\section{OBJETIVO}

O objetivo deste trabalho foi desenvolver uma metodologia de biodegradação dos compostos orgânicos presentes nos rejeitos radioativos líquidos orgânicos provenientes das atividades de reprocessamento do combustível nuclear, armazenados no Laboratório de Rejeitos Radioativos IPEN CNEN/SP, utilizand o comunidades bacterianas. 


\section{REVISÃO BIBLIOGRÁFICA}

\subsection{Gerência de rejeitos radioativos}

Os rejeitos radioativos podem ser classificados por diversos critérios: de acordo com a origem, o estado físico, os níveis de radioatividade, as quantidades de radionuclídeos de meia-vida longa e curta, a intensidade da radiação, os requisitos de deposição final ou com a toxicidade. Freqüentemente, adota -se uma combinação de critérios, dependendo das etapas da gerência dos rejeitos que necessitam ser implementadas .

O conjunto das atividades relativas ao rejeito, sejam administrativa ou operacional, desde sua geração até a deposição final é denominado gerência dos rejeitos radioativos. Cabe à gerência zelar por esses rejeitos enquanto constituírem fonte potencial de perigo. Não existe um modelo padrão de gerência, pois depende de fatores sociais, políticos, tecnológicos, e, também, da diversidade e da quantidade gerada. Um esquema genérico de gerência de rejeitos (AMPHLETT, 1961; IAEA, 1984; IAEA, 1983 ) é apresentado na FIG. 1 (HIROMOTO, 1999).

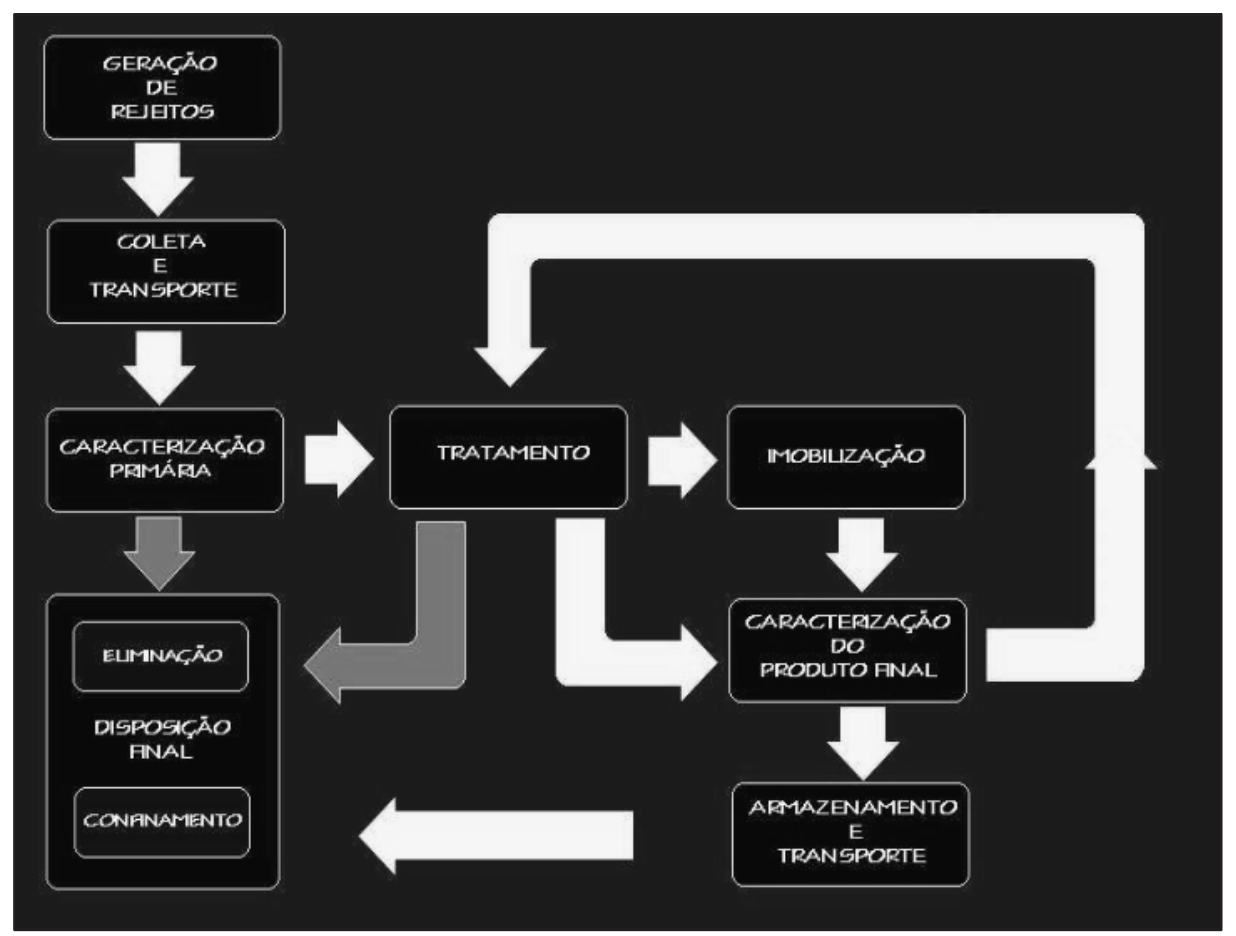

FIGURA 1- Fluxograma da gerência de rejeitos radioativos 
De todas as etapas da gerência, as que estão intimamente relacionadas com este trabalho são a caracterização primária e o tratamento. A caracterização primária dos rejeitos é a etapa na qual são realizados ensaios para determinação das propriedades físicas, químicas e radiológicas do rejeito. A caracterização visa assegurar o manuseio seguro do rejeito, a proteção do meio ambiente , a escolha adequada de processos e métodos para o tratamento e a imobilização. tratamento, por sua vez, consiste em um conjunto de ações que visam a redução de volume e o condicionamento físico e químico do rejeito, de forma a compatibilizá-lo com a matriz de imobilização e com os materiais de embalagem, e reduzir os custos das etapas posteriores da gerência de rejeitos radioativos.

A imobilização é a etapa posterior ao tratamento aplicada aos rejeitos radioativos que ainda não atendem os requisitos necessários para o armazenamento, transporte e deposição final. O objetivo da imobilização é converter o rejeito em uma forma sólida monolítica a fim de se criar uma barreira contra a liberação dos radionuclídeos presentes para o meio ambiente. As matrizes de imobilização mais empregadas são o cimen to, o betume e os polímeros. A escolha da matriz mais adequada depende de diversos fatores como a compatibilidade química com o rejeito, a disponibilidade comercial, o custo, a tecnologia relacionada e a qualidade do produto final.

No Brasil, a norma CNEN-NN-6.09 "Critérios de aceitação para deposição de rejeitos" (CNEN, 2002) estabelece que os rejeitos radioativos líquidos deverão ser incorporados em uma matriz, homogeneamente distribuídos e com um mínimo de material segregado, formando um produto monolí tico. $O$ atendimento a este item da norma para os rejeitos líquidos orgânicos representa um problema, uma vez que são incompatíveis com o cimento que é uma das principais matrizes de imobilização adotada no país. Antes disso, durante o armazenamento, os RRL O também representam um problema, pois $m$ uitos compostos orgânicos presentes nos RRLO são inflamáveis, alguns com pontos fulgor baixos. A degradação durante o armazenamento, por exemplo, pela radiólise, pode produzir gases e conduzi-los a frações com menores pontos de fulgor, e hidrogênio podendo assim gerar incêndios (IAEA, 2004).

Em outros países são empregados diversos métodos de tratamento para RRLO. São descritos na literatura métodos não destrutivos, como secagem e evaporação, destilação, condicioname nto físico/separação, absorção, 
imobilização direta, e destrutivos, como incineração, pirohidrólise, hidrólise alcalina, vitrificação, tratamento por plasma, métodos eletroquímicos, oxidação química direta, digestão ácida, microondas e o tratamento biológi co (IAEA, 2004). Apesar disso ainda não foi estabelecido uma tecnologia confiável e padronizada, que possa ser considerada como uma referência universal para o de tratamento e acondicionamento dos RRLO (FABIANO,1998).

Dentre os métodos citados, a incineração seria o método mais recomendado. No entanto, no Brasil, não há incineradores disponíveis para a queima de rejeitos radioativos, e a tecnologia necessária para a incineração é sofisticada e dispendiosa podendo apenas ser justificada para grandes quantidades de rejeitos a ser tratado (ENDO, 1991, FABIANO, 1998). A biodegradação tem sido proposta como uma alternativa à incineração para o tratamento dos RRLO por ser potencialmente mais segura, uma vez que a biodegradação não libera radioisótopos voláteis. Ou tra vantagem do uso da biodegradação é o processo, este podendo ser realizado a temperatura ambiente em cisternas ou contentores de forma que não ocorra nenhuma libera ção de resíduo para a biosfera (SCHWINKENDORF et al., 1995).

Outrossim, a utilização de microrganismos para o tratamento dos RRLO armazenados no Laboratório de Rejeitos Radioativos do IPEN/CNEN-SP surge como uma tecnologia bastante promissora. Esta abordagem baseia-se na utilização de microrganismos capazes de metabolizar os componentes orgân icos dos rejeitos, tornando-os compatíveis com a matriz de cimento (IAEA, 2004). Ainda, já que alguns rejeitos orgânicos representam perigo significante devido as suas características de volatilidade, flamabilidade, toxicidade e instabilidade química, empregar um processo que resulte em compostos menos tóxicos pode ser particularmente atrativo nos casos em que não $h$ aja instalações para deposição desses rejeitos ou critérios de aceitaç ão estabelecidos (AIEA, 2004).

O tratamento biológico tem sido aceito como um dos mais viáveis, ecológicos e uma opção compensadora para o trat amento de poluentes prejudiciais ao ambiente e à saúde (MUDLIAR et al., 2008). O processo usado é a biodegradação desses poluentes por microrganismos específicos, resulta ndo em compostos menos agressivos. Segundo SCHWINKENDORF et al. (1995), a biodegradação refere-se à degradação ou detoxificação de resíduos (municipais, industriais, perigosos ou misturas) por microrganismos, como bactérias ou fungos, 
resultando, geralmente, em dióxido de carbono e água. Se o processo for conduzido sob condições anaeróbicas haverá formação de dióxido de carbono e metano (AIEA, 2004).

Há na literatura diversos trabalhos sobre biodegradação de compostos orgânicos que incluem compostos orgânicos aromáticos, alifáticos, halogenados, hidrocarbonetos policíclicos aromáticos (PAHs), dioxinas, fenóis, hidrocarbonetos aromáticos clorados, ftalatos, policlorados bifenílicos, pesticidas, polímeros, ésteres de fosfato, éteres, terpenos, esteróis, aldeídos e ácidos e seus ésteres (ISHIKAWA, 1985; MACASKIE, 1991; IRWIN, 1995; OLIVERA et al., 1997; THOMAS et al., 1997a; THOMAS et al., 1997b; THOMAS \& MACASKIE, 1998; VANDERBERG et al.,1999; DOBLE \& KUMAR, 2005, STRINGFELLOW et al., 2004; BITTON, 2005).

A biodegradação é a mais adequada e econômica forma de trat amento de poluentes orgânicos, sendo aplicada no tratamento de efluentes dos mais diversos setores industriais, como nas indústrias de papel e celulose, têxtil, laticínios, abatedouros e frigoríficos, curtumes, químicas, petroquímicas, indústrias farmacêuticas, alimentícia, e bebidas (BITTON, 2005). Das tecnologias disponíveis envolvendo a biodegradação podem-se citar as lagoas de estabilização (aeróbia e anaeróbia), os filtros biológicos e o lodo ativado (BITTON, 2005; DOBLE \& KUMAR, 2005).

$\mathrm{Na}$ área ambiental, a biodegradação também é empregada na recuperação de áreas impactadas, por exemplo, locais onde ocorreram derramamento de óleo. Sob essa ótica, os hidrocarbonetos representam um dos principais contaminantes ambientais e na sua degradação são empregados microrg anismos selecionados, que possuem genes e enzimas específicas para ação nos diferentes compostos. Dentro da classe dos hidrocarbonetos, os n-alcanos são os mais facilmente degradáveis, podendo ser utilizados como parâmetro para avaliação da degradação do petróleo. (IRWIN, 1997; OLIVERA et al., 1997; DOBLE \& KUMAR, 2005).

DORONINA e colaboradores, (2006) em seu trabalho para o desenvolvimento de um biofiltro para o tratamento de acetatos de etila e metila ressaltam a importância e a dificuldade para o tratamento de efluentes contaminados com misturas de ésteres (em particular, acetatos de etila e metila) 
sendo a biodegradação uma abordagem promissora para o tratamento destes contaminantes.

Segundo STRINGFELLOW e colaboradores (2004) a biodegradação pode ser utilizada para o tratamento de RRLO contendo misturas de solventes e indicam que o desenvolvimento de um processo de biodegradação para o tratamento de RRLO é inteiramente viável.

VANDERBERG et al. (1999) descreve a utilização da biodegradação combinada com técnicas físicas para o tratamento de rejeitos radioativos orgânicos contendo tintas e solventes produzidos durante a descontaminação e desmantelamento de complexos de armas nucleares.

Em sua revisão sobre opções biotecnológicas para o tratamento de rejeitos do ciclo do combustível nuclear, MACASKIE (1991) discute a aplicação da biodegradação como opção para o tratamento de rejeitos radioativos líquidos orgânicos gerados nas atividades de reprocessamento do combustível nuclear, tendo como foco principal a biodegradação d o TBP por comunidades microbianas e cepas de Pseudomonas sp. e Citrobacter sp. .

Avaliando a eficiência de um sistema de lodo ativado em biodegradar o TBP, ISHIKAWA (1985) obteve, em 28 dias, uma porcentagem de degradação de $89 \%$. Apoiando estes resultados, THOR (1989) em outro estudo de 28 dias, obteve uma porcentagem de degradação do TBP de 90,8\%. Com base nesses resultados o United Nations Environment Programme (2001) afirma que o TBP é um composto biodegradável.

THOMAS e colaboradores (1997 a) avaliaram a capacidade de biodegradação do TBP por culturas mistas de pseudômonas, sendo verificado que a taxa de consumo do TBP, assim como a de crescimento foram variáveis, podendo ser divididas em rápida e lenta. $\mathrm{O}$ autor sugere que as taxas rápidas de degradação estão relacionadas com a produção de fosforoesterases, pelas cultruras testadas, que atuariam diretamente na quebra do TBP.

THOMAS \& MACASKIE (1998) avaliaram diversos parâmetros que influenciam a capacidade de biodegradação do TBP como $\mathrm{pH}$, temperatura, incorporação de metais, adição de querosene, fosfato inorgânico e sulfato, sendo as melhores condições para a biodegradação o cultivo em pH 7 e temperatura de incubação de $30^{\circ} \mathrm{C}$. 
Em 1993 foi depositado um pedido de patente por DEGUITRE \& STINGRE para aplicação de um processo de biodegradação para o tratamento de RRLO consistindo na utilização de bactérias pré -selecionadas para a hidrólise dos compostos orgânicos e posterior imobilização dos compostos inorgânicos e da biomassa em cimento. Em 2003, GARCIA patenteou um processo de biodegradação de TBP utilizando bactérias fotossintetizantes aplicado ao processo de tratamento de efluentes industriais .

\subsection{Principais compostos orgânicos utilizados no processo PUREX}

\subsubsection{Tri-butilfosfato}

O tri-butilfosfato (TBP) é um líquido não inflamável, não explosivo, incolor e sem cheiro. É fabricado em larga escala por meio da esterificação do ácido ortofosfórico com o álcool butílico, com uma produção mundial estimada em 3.000 e 5.000 toneladas anuais. Sua fórmula química é $\left(\mathrm{CH}_{3} \mathrm{CH}_{2} \mathrm{CH}_{2} \quad \mathrm{CH}_{2} \mathrm{O}\right)_{3} \mathrm{PO}$. (NAKAMURA, 1991; JETOC, 2008).

O TBP é usado como solvente para ésteres de celulose, vernizes, plastificador primário em manufaturas de plásticos, resinas viní licas, fluido hidráulico, solvente para extração e purificação de metais de terras raras. Como não possui cheiro, é aplicado como agente anti -espumante, detergente, e em várias emulsões, tintas e adesivos. Na indústria nuclear o TBP é utilizado, geralmente, diluído em dodecano ou n-parafinas e aplicado no processo extração por solvente de urânio, plutônio e tório do combustível nuclear irradiado. (NAKAMURA, 1991; FORBICINI, 1994).

Os principais riscos envolvendo a utilização do TBP é a contaminação do meio ambiente, pois o TBP é freqüentemente encontrado em amostras de ar, água, sedimentos e em organismos aquáticos, coletadas em áreas próximas a fábricas de papel. Para a saúde humana estudos in vitro, demonstraram que o TBP possui efeitos neurotóxicos e um rápido efeito inibidor da colinesterase (NAKAMURA, 1991; JETOC, 2008).

A via metabólica de biodegradação do TBP não foi elucidada até o momento, por este motivo, a FIG. 2 representa uma fórmula geral dos compostos organofosforados e a principal via de degra dação (MACASKIE, 1991, SINGH \& WALKER, 2006; BERNE et al. 2004). 


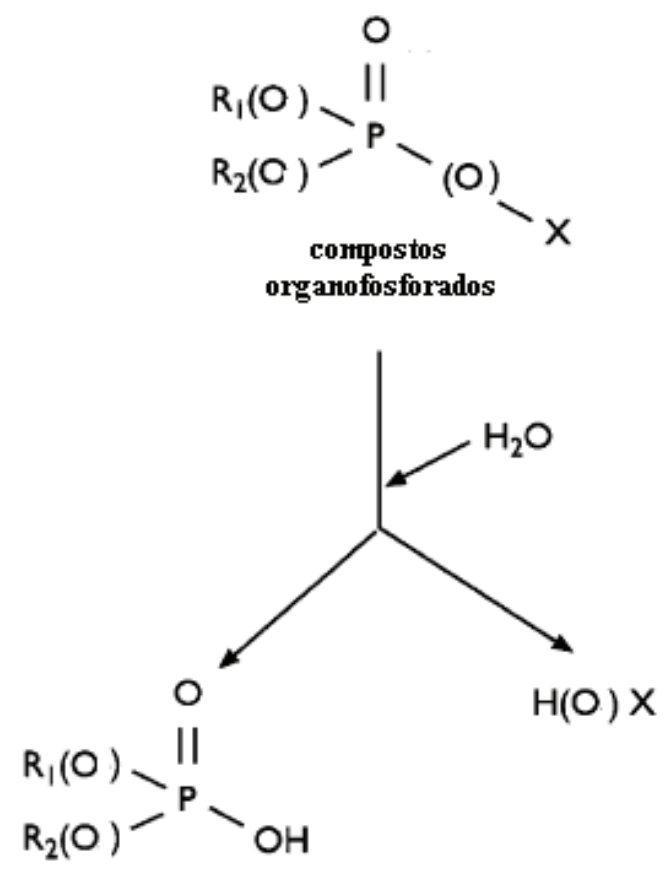

FIGURA 2- Fórmula geral dos compostos organofosforados e principal via de degradação (SINGH \& WALKER, 2006).

\subsubsection{Alcanos}

Os alcanos, também chamados parafinas, são hidrocarbonetos alifáticos acíclicos, de fórmula geral $\mathrm{C}_{n} \mathrm{H}_{2 n+2}$, apresentando-se em cadeias lineares ou ramificadas. São menos densos que a água e, praticamente, insolúveis na mesma. Os pontos de fulgor e ebulição dos alcanos, geralmente, aumentam com o peso molecular e com o comprimento da cadeia carbônica principal, em condições normais de temperatura e pressão. Do $\mathrm{CH}_{4}$ até $\mathrm{C}_{4} \mathrm{H}_{10}$, os alcanos são gasosos, do $\mathrm{C}_{5} \mathrm{H}_{12}$ até $\mathrm{C}_{17} \mathrm{H}_{36}$, líquidos e, acima de $\mathrm{C}_{18} \mathrm{H}_{38}$, são sólidos (IRWIN et al.;1997; BRUICE, 2006 ).

O uso dos alcanos é determinado em função do número de átomos de carbono que eles possuem. Alcanos de um a quatro carbonos são usados, principalmente, para aquecimento, de cinco a dezessete carbonos, são usados como combustíveis em motores de combustão interna e co mo solventes para substâncias não-polares. No reprocessamento do combustível nuclear irradiado estes alcanos são utilizados no processo PUREX como solvente para o TBP. Alcanos com cadeia de aproximadamente 35 ou mais átomos de carbono são encontrados em betume, utilizado, por exemplo, na superfície das estradas. No 
entanto, os maiores alcanos têm pouco valor e são, geralmente, divididos em alcanos menores por craqueamento (IRWIN et al.; 1997; ISHIGURO, 2001; BRUICE, 2006). Diversos riscos estão envolvidos na utilização dos alcanos, que são em sua maioria voláteis e inflamáveis, podendo ser prejudiciais a saúde se inalados, causando irritação às mucosas, olhos, vias respiratórias e deprimindo o sistema nervoso central ou, até mesmo, mortais em caso de ingestão. A exposição prolongada à alcanos pode causar efeitos entorpecentes ( OAK RIDGE NATIONAL LABORATORY, 1989; IRWIN et al., 1997).

Os alcanos são facilmente degradados no ambiente quando comparados a outros hidrocarbonetos, sendo os de cadeia reta mais fa cilmente degradados que os de cadeia ramificada (DOUGLAS et al., 1992). Muitos organismos, incluindo diversas pseudômonas sp, são capazes de usar alcanos lineares como sua única fonte de carbono e energia. Na FIG. 3, está representada a via metabólica de degradação do n-octano (WILLS et al.,2008).

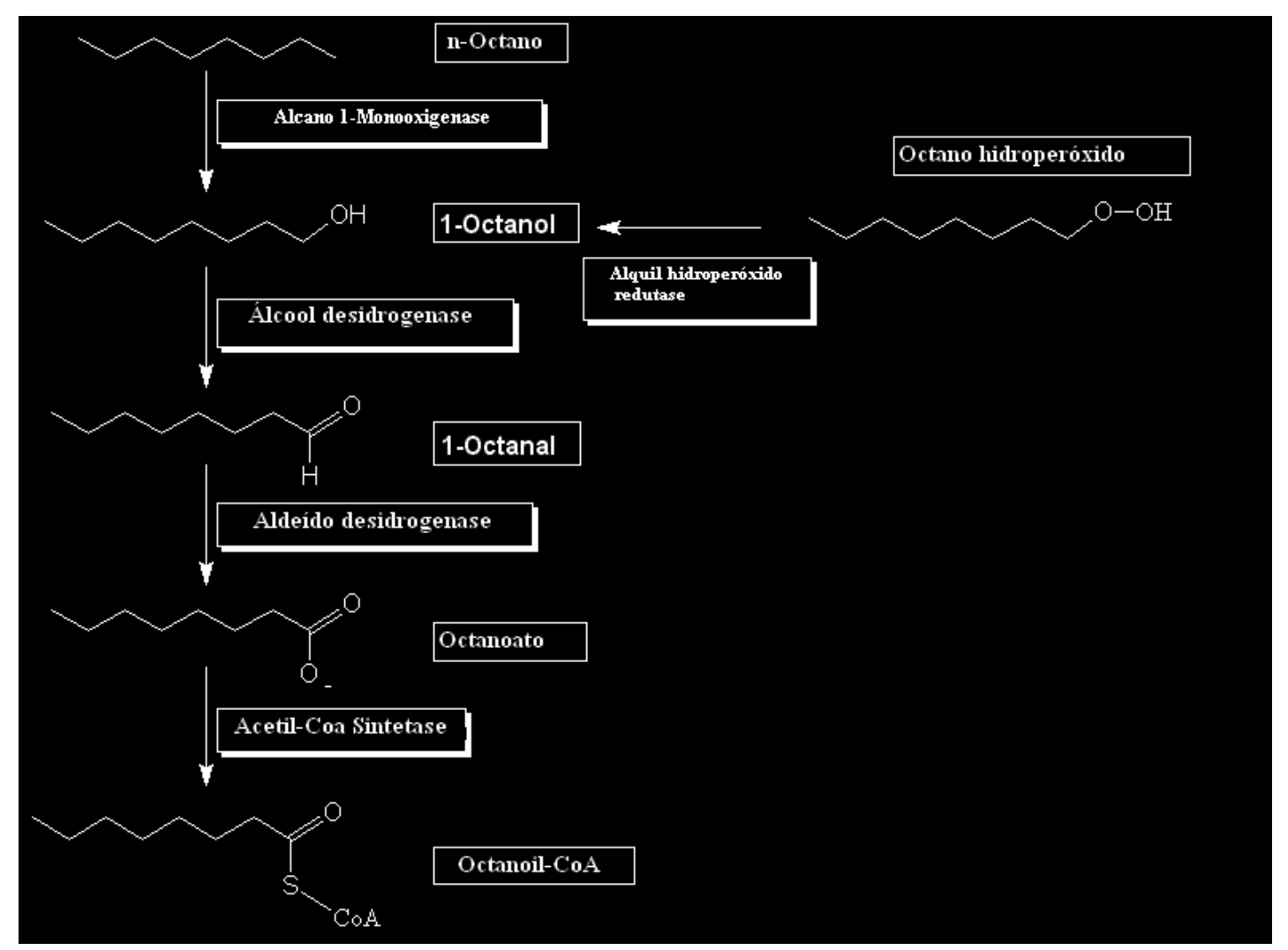

FIGURA 3: Via de degradação metabólica do n-octano, realizado pela $P$. oleovorans (atual $P$. putida). 


\subsubsection{Acetato de etila}

O acetato de etila é um éster fabricado em larga escala devido ao seu alto poder de solvência. É um líquido límpido, incolor e com o odor forte e frutal, obtido pela reação do ácido acético com o etanol. É um composto difícil de ser degradado e sua fórmula química é $\mathrm{CH}_{3} \mathrm{COOC}_{2} \mathrm{H}_{5}$ (DORONINA et al 2006, JT BAKER, 2008, RHODIA, 2002 ).

O acetato de etila encontra ampla aplicação nas indústrias de tintas, vernizes, adesivos, thinners, removedores, filmes fotográficos, explosivos, recobrimento para papeis, produtos farmacêuticos, processamento de alimentos, perfumes, aromas e acabamento em couro sintético, além de ser utilizado como solvente em análises cromatográficas (JT BAKER, 2008; RHODIA, 2002).

Os principais riscos envolvendo a utilização do acetato de etila estão relacionados à sua capacidade de ser parcialmente miscível em água, podendo contaminar esgotos, rios, córregos e outras correntes de água; ser inflamável reagindo com, oxidantes, álcalis e ácidos e oferecer potenciais riscos a saúde como nefrotoxidade e hepatotoxidade podendo causar anemia com leucocitose (DORONINA et al 2006, JT BAKER, 2008, RHODIA, 2002).

A via de degradação metabólica do acetato de etila est á esquematizada na FIG. 4:

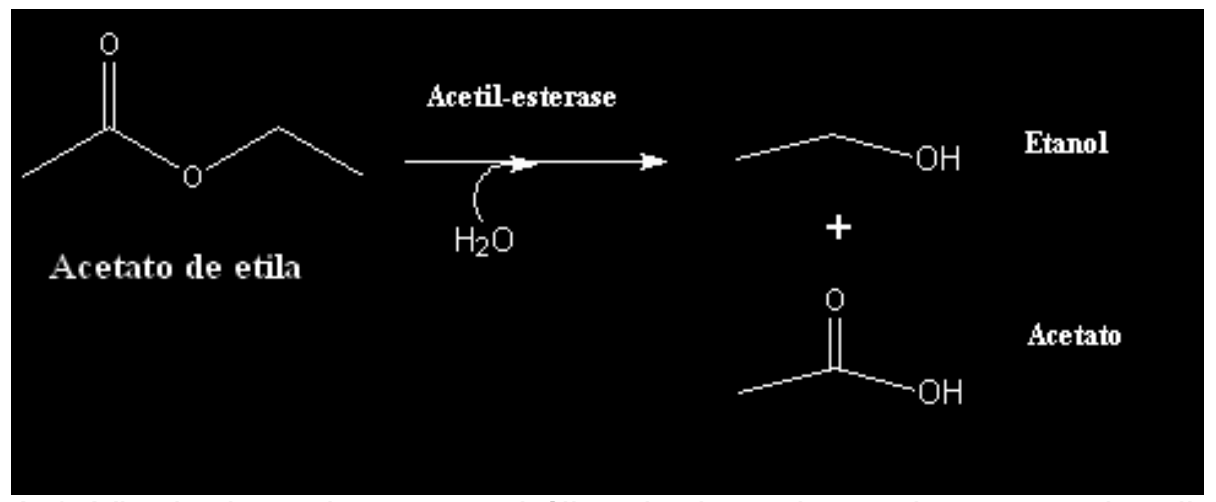

FIGURA 4: Via de degradação metabólica da degradação de acetato de etila (UM BBD, 2008). 


\section{METODOLOGIA}

Este trabalho pode ser dividido e m três etapas, caracterização dos RRLO, obtenção e estudo das comunidades microbianas e realização de ensaios de biodegradação dos RRLO.

Na primeira etapa, os compostos orgânicos presentes nos RRLO foram identificados por duas técnicas de cromatografia gas osa (CG), a de injeção direta e a "Headspace". A técnica de injeção direta forneceu a identificação e quantificação dos compostos orgânicos não voláteis, como o TBP, ao passo que a "Headspace" dos voláteis. Juntamente com a identificação dos compostos orgânicos. Os RRLO também foram avaliados quanto à presença de microrganismos por contagem padrão em placa. Na segunda etapa, as comunidades bacterianas foram obtidas e estudadas quanto à capacidade de sobrevivência, crescimento e degradação nos RRLO e seus co nstituintes orgânicos. Isto possibilitou o estudo da biodegradação dos principais constituintes da fase orgânica dos RRLO. Na terceira etapa foram realizados os ensaios de biodegradação dos RRLO.

As comunidades bacterianas utilizadas nos experimentos fora $\mathrm{m}$ obtidas a partir de amostras de solo e água da mina de urânio de Poços de Caldas (MG) e sedimentos do estuário de São Sebastião (SP).

Um esquema com as três etapas está apresentado na FIG. 5. 


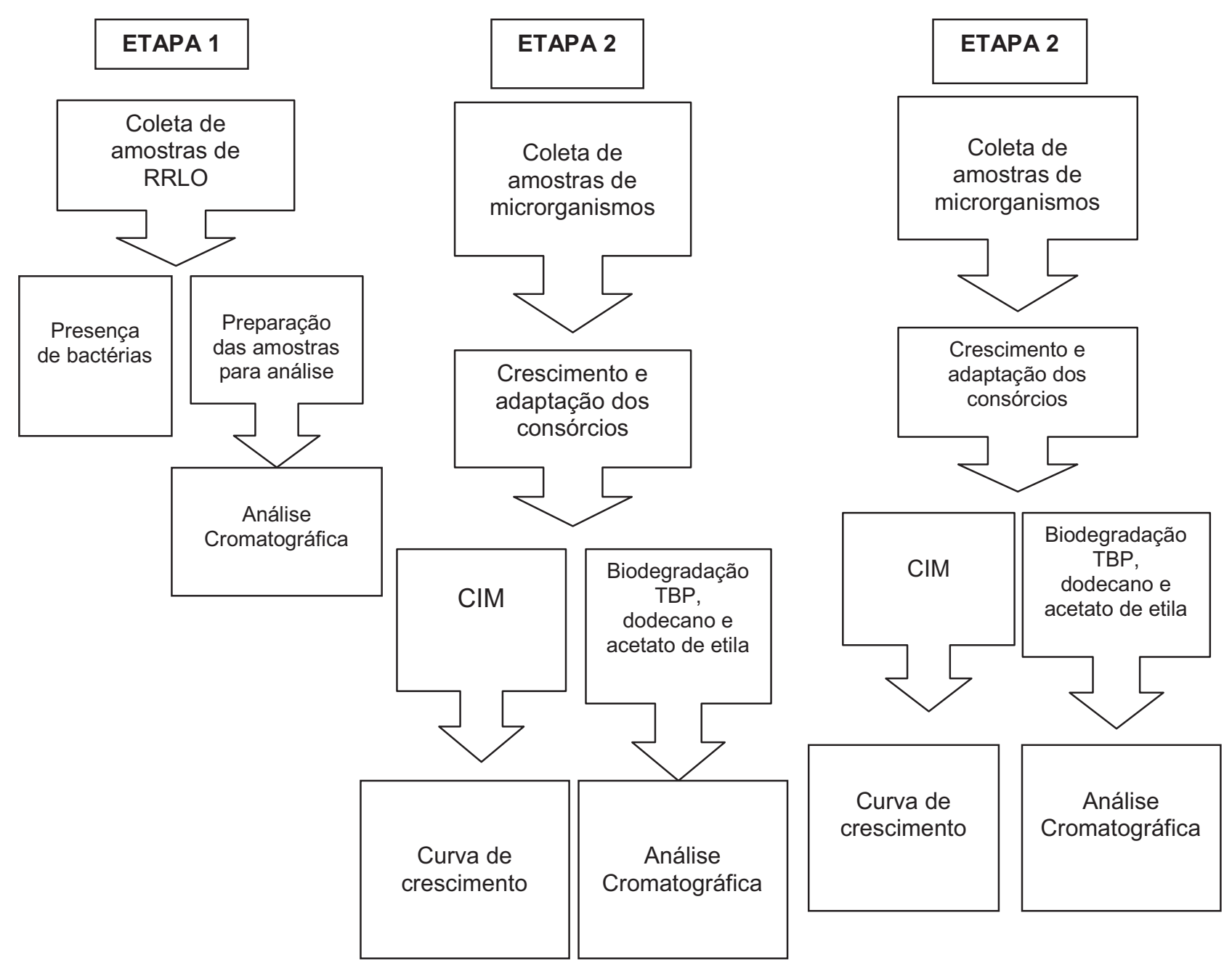

FIGURA 5: Representação esquemática da metodologia utilizada para 0 desenvolvimento da técnica de biodegradação dos RRLO. 


\subsection{Caracterização dos rejeitos}

O RRLO, objeto deste estudo, é proveniente das atividades de pesquisa e desenvolvimento na área de reprocessamento do combustível nuclear.

Atualmente, estão armazenados na unidade de armazenamento e tratamento de rejeitos radioativos líquidos e sólidos úmidos do Laboratório de Rejeitos Radioativos - Instituto de Pesquisa Energéticas e Nucleares/Comissão Nacional de Energia Nuclear - São Paulo (LRR-IPEN/CNEN-SP), 17 embalagens (TAB 1), contendo rejeitos de $\mathrm{Pu}^{238,239}, \mathrm{Am}^{241}, \mathrm{U}^{235,238}$ e produtos de fissão provenientes da antiga CELESTE, totalizando 340 litros (DELLAMANO, 2005).

TABELA 1: Embalagens de RRLO armazenadas no (LRR-IPEN/CNEN-SP), provenientes do reprocessamento do combustível nuclear e suas atividades em $\mathrm{Bq} / \mathrm{L}$.

\begin{tabular}{cccccc}
\hline RRLO & $\mathbf{A m}^{241}$ & $\mathbf{C s}^{137}$ & $\mathbf{P u}^{236}$ & $\mathbf{P u}^{239}$ & $\mathbf{U}$ (Total) \\
\hline 016 & $50 \pm 15$ & $17 \pm 3$ & $38 \pm 5$ & $28,6 \pm 12,7 \times 10^{1}$ & $30171 \pm 302$ \\
071 & $70000 \pm 6500$ & $<150$ & $13,6 \times 10^{4} \pm 3,0 \times 10^{4} 13,2 \times 10^{6} \pm 12,6 \times 10^{6} 8592442 \pm 17185$ \\
072 & $3580 \pm 310$ & $1200 \pm 100$ & $15,8 \pm 3,1$ & $16,1 \times 10^{2} \pm 8,1 \times 10^{1}$ & $1231 \pm 66$ \\
073 & $17 \pm 3$ & $<10$ & $18,2 \times 10^{2} \pm 1,9 \times 10^{2}$ & $18,7 \times 10^{4} \pm 1,6 \times 10^{4}$ & $246 \pm 12$ \\
074 & $115000 \pm 1100$ & $<80$ & $20,0 \times 10^{3} \pm 3,5 \times 10^{3} 18,5 \times 10^{5} \pm 2,7 \times 10^{3}$ & $12394 \pm 124$ \\
075 & $100 \pm 6$ & $16 \pm 3$ & $4,8 \times 10^{1} \pm 0,9 \times 10^{1}$ & $4,2 \times 10^{2} \pm 2,5 \times 10^{1}$ & $2603 \pm 52$ \\
076 & $15000 \pm 1450$ & $<80$ & $64,7 \times 10^{2} \pm 8,1 \times 10^{2} 61,0 \times 10^{4} \pm 6,9 \times 10^{4}$ & $6188 \pm 124$ \\
077 & $40 \pm 5$ & $30 \pm 5$ & $3,9 \times 10^{1} \pm 0,9 \times 10^{1} 24,3 \times 10^{2} \pm 2,12 \times 10^{2}$ & $78 \pm 8$ \\
078 & $<15$ & $45 \pm 6$ & $1,010^{2} \pm 0,8 \times 10^{2}$ & $3,8 \times 10^{2} \pm 0,3 \times 10^{2}$ & $4539 \pm 91$ \\
079 & $32000 \pm 3000$ & $310 \pm 40$ & $14,4 \times 10^{2} \pm 2,6 \times 10^{2}$ & $13,9 \times 10^{4} \pm 2,0 \times 10^{4}$ & $1171 \pm 60$ \\
080 & $3600 \pm 3000$ & $360 \pm 40$ & $1,1 \times 10^{3} \pm 0,2 \times 10^{3}$ & $10,1 \times 10^{4} \pm 1,8 \times 10^{4}$ & $8790 \pm 176$ \\
081 & $1800 \pm 200$ & $85 \pm 9$ & $1,6 \times 10^{3} \pm 0,2 \times 10^{3}$ & $15,2 \times 10^{4} \pm 1,3 \times 10^{4}$ & $4113 \pm 205$ \\
082 & $13000 \pm 1150$ & $<80$ & $12,3 \times 10^{2} \pm 2,1 \times 10^{2}$ & $15,9 \times 10^{4} \pm 4,9 \times 10^{3}$ & $1088 \pm 50$ \\
083 & $<15$ & $95 \pm 9$ & $9,9 \pm 2,5$ & $6,9 \times 10^{2} \pm 3,4 \times 10^{1}$ & $5847 \pm 117$ \\
084 & $2900 \pm 230$ & $<80$ & $3,5 \times 10^{1} \pm 0,5 \times 10^{1}$ & $7,0 \times 10^{2} \pm 3,4 \times 10^{1}$ & $365 \pm 36$ \\
085 & $170000 \pm 150027000 \pm 18003,3 \times 10^{3} \pm 0,6 \times 10^{3}$ & $23,6 \times 10^{4} \pm 1,3 \times 10^{4}$ & $4314 \pm 215$ \\
086 & $220 \pm 18$ & $90 \pm 10$ & $6,0 \times 10^{1} \pm 1,6 \times 10^{1}$ & $29,2 \times 10^{2} \pm 2,5 \times 10^{2}$ & $6627 \pm 132$ \\
\hline
\end{tabular}


Todos os rejeitos armazenados no LRR provenientes da CELESTE são compostos por uma mistura bifásica de solução aquosa de solventes orgânicos e compostos inorgânicos, possivelmente, TBP, n-dodecano, ácido nítrico, carbonato de sódio, nitrito de sódio, fluoreto de sódio, hidroxi lamina, nitrato de alumínio, acetona, etanol, nitrito de sódio, xileno, ácido nítrico, hidróxido de sódio, piridina, hexano e oxalato de potássio.

Para a análises da fase orgânica dos RRLO por cromatografia, foram realizadas extrações da fração orgânica com diclorometano em um funil de separação, na proporção 1:1. A fase orgânica foi separada em um frasco de vidro com capacidade para $25 \mathrm{~mL}$ e antes de serem enviadas para a cromatografia, as amostras foram analisadas quanto à presença de radionuclídeos. Esta análise foi realizada por meio de monitoramento de papéis de filtros impregnados com $1 \mathrm{~mL}$ da extração de cada rejeito em contadores Alfa (Eberline Scintillation Alpha Counter SAC-4), Beta (Eberline BC-4) e espectrômetro Gama (contador automático HPGe Canberra, model GX2518). Somente as amostras sem radionuclídeos foram utilizadas para a determinação dos compostos orgânicos. Todas as análises foram realizadas em duplicata.

Para uma avaliação prévia dos rejeitos e confrontação das informações obtidas com gerador, empregou-se a análise por cromatografia gasosa das extrações dos RRLO utilizando o cromatógrafo Shimadzu (GC-QP5050), do Laboratório de Tratamento de Solventes do Instituto de Química da Universidade de São Paulo (IQ-USP). As amostras foram injetad as a $300^{\circ} \mathrm{C}$ e os compostos foram separados em uma coluna DB-5 J\&W coluna $(30 \mathrm{~mm} \times 0,25 \mu \mathrm{m}$ d.i; espessura do filme $0,25 \mathrm{~mm})$ utilizando como gás de arraste o hélio $(1,3 \mathrm{~mL} / \mathrm{min})$. A temperatura inicial da coluna foi de $40^{\circ} \mathrm{C}$, mantida por 2 min e, então a temperatura foi gradativamente aumentada até $250{ }^{\circ} \mathrm{C}\left(5^{\circ} \mathrm{C} / \mathrm{min}\right)$ e mantida por $15 \mathrm{~min}$, para garantir a saída de todos os compostos. Com os resultados, foram selecionadas as embalagens 80 e 85 por conterem as maiores concentrações de radionuclídeos e melhor represent arem o fluxo de rejeitos do reprocessamento.

Amostras dessas embalagens foram novamente analisadas por CG/MS e CGMS/Headspace na tentativa de se realizar uma avaliação semiquantit ativa dos compostos presentes. As análises foram realizadas na Central Analí tica do IQUSP, utilizando o cromatrógafo Shimadzu "Headspace" modelo GCMS -QP5050, com amostrador automático "Headspace" HSS-4A. As amostras foram 
introduzidas com um injetor "split/splitless" (split de $1: 14$ ) a $250^{\circ} \mathrm{C}$ utilizando como gás de arraste hélio (1,3 mL/min) a separação foi feita com uma coluna DB -5 J\&W (30 $\mathrm{m} \times 0,25 \mathrm{~mm}$ d.i. espessura do filme $0,25 \mu \mathrm{m}$ ). A temperatura inicial da coluna foi de $40{ }^{\circ} \mathrm{C}$, mantida por 2 min, sendo aumentada à razão de $3{ }^{\circ} \mathrm{C}$ por min até 65 ${ }^{\circ} \mathrm{C}$, mantendo-se por $1 \mathrm{~min}$, então nova mente aumentada até $220^{\circ} \mathrm{C}\left(15^{\circ} \mathrm{C} / \mathrm{min}\right) \mathrm{e}$ mantida nesta temperatura por 3 minutos para garantir a saída de todos os compostos. A temperatura de interface do $\mathrm{MS}$ foi $230^{\circ} \mathrm{C}$. O espectrômetro de massas foi operado em modo varredura (impacto de elétron à $70 \mathrm{eV}-1000 \mathrm{~V}$ ).

As análises dos RRLO por "Headspace" foram realizadas com amostras in natura, enviadas em frascos de vidros com capacidade para $20 \mathrm{~mL}$, fechadas com septos de teflon e lacres de alumínio.

\subsection{Obtenção e estudo das comunidades microbianas}

\subsubsection{Avaliação dos RRLO quanto à presença de microrganismos}

Nesta etapa foi avaliada a presença de microrganismos neutrófilos e acidófilos nos RRLO provenientes das atividades de reprocessamento armazenados no LRR. A avaliação limitou-se a estas duas populações de microrganismos, pois o $\mathrm{pH}$ médio dos RRLO armazenados é 3 inviabilizando o crescimento de microrganismos basófilos. Para esta avaliação foi utilizada a técnica de contagem padrão em placas, realizada de acordo com o "Standard Methods for the Examination of Water and Wastewater" (1995). Foram retiradas assepticamente alíquotas de $10 \mathrm{~mL}$ de cada amostra de RRLO e transferidas para tubos estéreis contendo $90 \mathrm{~mL}$ de solução tampão $(\mathrm{pH}=7,2)$, preparada a partir de uma mistura de solução $\mathrm{KH}_{2} \mathrm{PO}_{4}$ 0,25M e $\mathrm{MgCl}_{2}$ 0,4M. Com essa solução foram realizadas diluições sucessivas, em um intervalo entre $10^{-1}$ e $10^{-7}$, de onde foram retiradas alíquotas de $1 \mathrm{~mL}$ e inoculadas em placas de petri contendo 15 $\mathrm{mL}$ de ágar padrão para contagem (Acumedia), previamente autoclavado e resfriado à temperatura de 44 a $46{ }^{\circ} \mathrm{C}$. De cada diluição foram preparadas placas em quadruplicata, duas reservadas para aerobiose e, as outras duas para anaerobiose. Após a homogeneização e solidificação, as placas foram incubadas em estufa de cultura, a $37^{\circ} \mathrm{C}$, por 48 horas. Para a incubação em atmosfera de anaerobiose utilizou-se jarras de anaerobiose e geradores de $\mathrm{CO}_{2}$ da Probac do Brasil. Após esse período, procedeu-se a contagem das colônias. 
Para avaliação da contaminação por microrganismos mesofilos acidófilos o pH da solução tampão e do ágar padrão para contagem foi ajustado para 3 utilizando uma solução 0,1 M de ácido clorídrico.

\subsubsection{Ensaios de biodegradação dos principais compostos orgânicos presentes nos RRLO.}

Nesta etapa foram realizados ensaios p ara a avaliação da degradação dos principais compostos orgânicos que constituem os RRLO, por culturas mistas de bactérias provenientes de solos e água de locais com características distintas.

\subsubsection{Origem das comunidades microbianas}

Foram selecionadas comunidades de microrganismos provenientes de áreas impactadas, a mina de urânio de Poços de Caldas , MG (FIG. 6) e do canal de São Sebastião, SP.

A mina de urânio de Poços de Caldas foi a primeira a ser prospectada no Brasil e entrou em operação em feve reiro de 1982. Está localizada no platô de Poços de Caldas (FIG.7) e consiste de uma cova aberta, uma instalação de trituração e uma fábrica de moagem para processamento químico. A esse conjunto foi dada a denominação "Complexo Industrial de Poços de Caldas" (CIPC) (FERNANDES et al, 1995; GONÇALVES, 2006). Até julho de 1996, quando a mina foi desativada, o CIPC gerou $44.560 .000 \mathrm{~m}^{3}$ de rejeitos de mineração, estes materiais foram dispostos em grandes áreas circunvizinhas da região mineradora, denominadas de "bota-foras" (NASCIMENTO, 1998). Estas áreas tornaram-se uma fonte de drenagem ácida que ocorre quando os minerais sulfetados, dentre eles a pirita, são oxidadas por exposiç ão à água e oxigênio ou pela atividade de microrganismos produzindo um efluente cont endo ácido sulfúrico e metais dissolvidos. O ácido sulfúrico produzido cria um ambiente hostil, promovendo a solubilização de radionuclídeos (urânio, tório e radio) e elementos estáveis (manganês, ferro, zinco, fluoreto, etc) em níveis de concentração acim a dos valores permitidos pela legislação para o lançamento direto no ambiente, causando a inibição do crescimento de plantas de cobertura, a erosão do solo e a possível acidificação dos aqüíferos adjacentes. (AMARAL et al, 1985; FERNANDES et al, 1995; GONÇALVES, 2006). Atualmente, o complexo se encontra em processo de descomissionamento (GONÇALVES, 2006). 


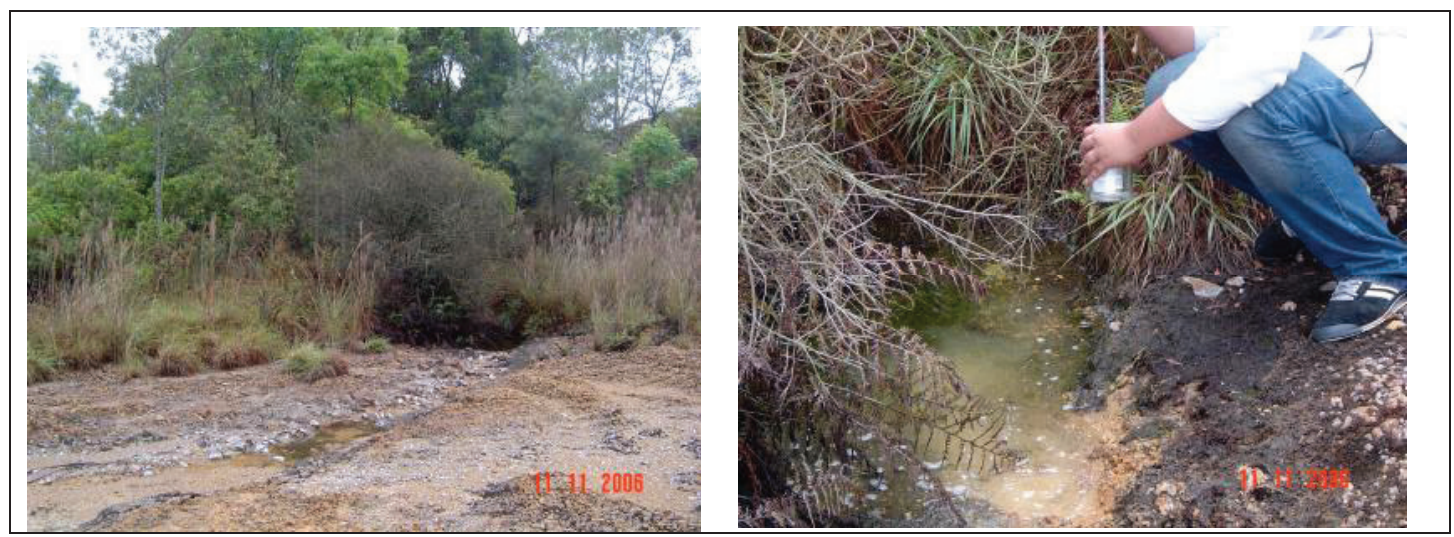

FIGURA 6: Local de coleta das amostras: Bia e Bia Lago

O canal de São Sebastião está localizado no litoral norte do Estado de São Paulo (FIG.8) e é protegido pela ilha de mesmo nome, que pertence ao município de Ilhabela. Nele situam-se o porto de cargas secas, com um berço para navios de carga, e o terminal petrolífero, com quatro berços, por onde é descarregado cerca de $60 \%$ do petróleo movimentado no país, bem como derivados como nafta e querosene de aviação (POFFO et al. 1996). O canal de são Sebastião foi escolhido para o nosso estudo, pois todo este conjunto de atividades de carga e descarga de petróleo além da ocupação desordenada da região expõem os ecossistemas costeiros na região do canal a uma variedade de impactos de origem antrópica (POFFO et al., 1996). Além disso, o local já sofreu diversos derramamentos de óleo, como o ocorrido no ano de 2000, quando um navio petroleiro colidiu com um píer e derramou $86 \mathrm{~m}^{3}$ no canal, atingindo 9 praias de São Sebastião e 7 de Ilha Bela. (SUGIMOTO, 2003)

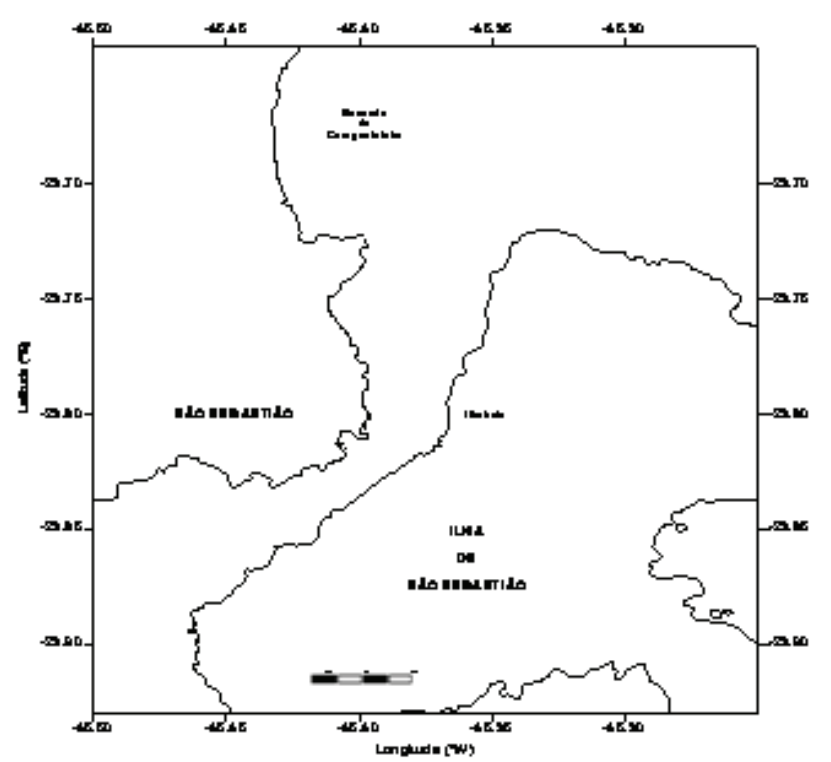

FIGURA 8: Mapa do estuário de São Sebastião (MEDEIROS \& BÍCEGO, 2004) 
Da mina de urânio foram coletados o solo, pela existência de metais pesados, e água devido a sua acidez. O sedimento do estuário de São Sebastião foi doado pelo Instituto Oceanográfico da Universidade de São Paulo (IO -USP) e é proveniente de uma área impactada com hidrocarbonetos.

A amostra denominada BIA foi coletada no solo da mina de urânio de Poços de Caldas foi coletada na coordenada S $21^{\circ} 56^{\prime}$ ' 19 . 0 ' WO 46 $29^{\circ}$ ' 47. $5^{\prime}$ a amostra de água no ponto BIA LAGO coordenada S $21^{\circ} 56^{\prime} 20$. 8 ' WO 46 - $29^{\prime} 13.5^{\prime}$, e a amostra de sedimento do estuário de São Sebast ião foi coletada na coordenada S $23^{\circ} 47^{\prime} 44$. 4' S WO $45^{\circ} 22^{\prime} 85$. $0^{\prime}$.

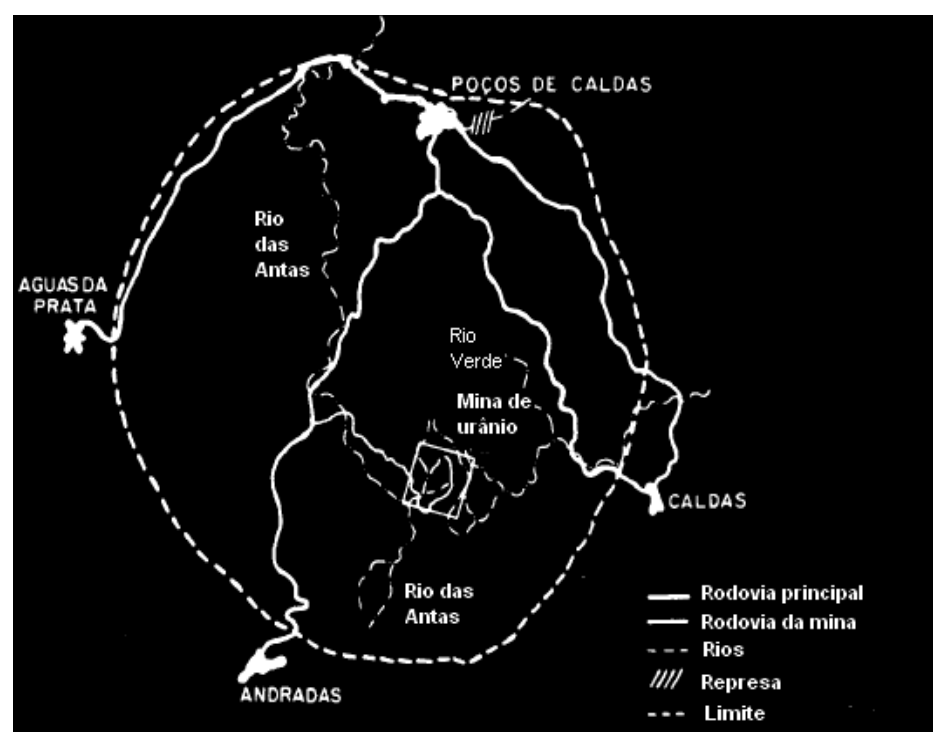

FIGURA 7: Platô de Poços de Caldas (AMARAL et al, 1985)

\subsubsection{Obtenção das comunidades microbianas}

Para obtenção das comunidades bacterianas, as amostras de água, solo e sedimento foram submetidas ao processo de enriquecimento descrito por (CRAVO JÚNIOR, 1998), com o objetivo de selecionar e aumentar a população de bactérias capazes de degradar hidrocarbonetos e acetato de etila. Nesse sentido incubou-se 10 gramas de solo, $10 \mathrm{~g}$ de sedimentos ou $10 \mathrm{~mL}$ de água em $100 \mathrm{ml}$ de meio mínimo (RODRIGUES, 2002), aqui denominado meio mínimo D, constituído por $\left(\mathrm{NH}_{4}\right) 2 \mathrm{SO}_{4} \quad 2,13 \mathrm{~g} / \mathrm{L}, \quad \mathrm{KH}_{2} \mathrm{PO}_{4} \quad 1,7 \mathrm{~g} / \mathrm{L}, \quad \mathrm{K}_{2} \mathrm{HPO}_{4} \quad 4,39 \mathrm{~g} / \mathrm{L}$, $\mathrm{MgSO}_{4} .7 \mathrm{H}_{2} \mathrm{O} 0,11 \mathrm{~g} / \mathrm{L}, \mathrm{FeSO}_{4} .7 \mathrm{H}_{2} \mathrm{O} 0,01 \mathrm{~g} / \mathrm{L}, \mathrm{CaCl}_{2} \cdot 2 \mathrm{H}_{2} \mathrm{O} 0,003 \mathrm{~g} / \mathrm{L}, \mathrm{MnSO}_{4} \cdot 2 \mathrm{H}_{2} \mathrm{O}$ $0,05 \mathrm{~g} / \mathrm{L}$ e $1 \% \mathrm{v} / \mathrm{v}$ de contendo óleo diesel, TBP e acetato de etila como fonte de carbono. Posteriormente, foram realizados 3 repiques sucessivos em intervalos 
de 48 horas, variando de 1 a 5 \% (v/v) a concentração de TBP, dodecano, acetato de etila e óleo diesel no meio mínimo $D$. Os experimentos foram realizados em frascos com tampa de rosca com $250 \mathrm{~mL}$ de capacidade. Todos os frascos foram incubados em plataforma de agitação (150 rpm) à $30^{\circ} \mathrm{C}$ e após o período de incubação, parte da cultura obtida foi estocada em tubos criogênicos contendo $30 \%$ de glicerol estéril à temperatura de $-20^{\circ} \mathrm{C}$.

Antes da determinação da capacidade de degradação dos compostos orgânicos pelas comunidades bacterianas foram avaliados fatores que pudessem interferir no crescimento dos microrga nismos e influenciar na degradação, sendo determinada a concentração inibitória mínima (CIM) e avaliado o crescimento microbiano em contato com os RRLO.

A CIM representa a concentração mínima de uma substância em um meio para a qual não se observa o cres cimento de microrganismos (NCCLS, 2003). A CIM dos RRLO foi determinada pelo método de macrodiluição em caldo, conforme recomendado pelo "National Committee for Clinical Laboratories Standards" (NCCLS, 2003). As culturas mistas foram repicadas em caldo LuriaBertani (LB) (Biolife $®)$ composto por $10 \mathrm{~g}$ Triptona bacteriológica, $5 \mathrm{~g}$ de extrato de levedura $10 \mathrm{~g} \mathrm{NaCl}$ ) e incubadas em estufa a $30^{\circ} \mathrm{C}$ até a obtenção de uma densidade bacteriana na cultura de $1,5 \times 10^{8}$ Unidades Formadoras de Colônia por $\mathrm{mL}$ (UFC/mL). Esta suspensão foi diluída 10 vezes em solução salina $(\mathrm{NaCl}$, 0,85\%) estéril e, posteriormente, alíquotas de $1 \mathrm{~mL}$ desta diluição foram inoculadas em tubos $\left(1,5 \times 10^{7}\right.$ UFC/tubo) contendo concentrações dos RRLO variando de $1 \%$ a $64 \%$ preparadas com os meios de cultura a se rem testados. Após os períodos de incubação $\left(24,48\right.$ e 72 horas) a $30^{\circ} \mathrm{C}$ a CIM foi determinada comparando-se o crescimento nos tubos contendo as diluições dos RRLO com o crescimento em tubos controle (sem RRLO) e por inoculação das comunidades em ágar nutriente (Biolife $®)$.

A avaliação do crescimento microbiano foi obtida por meio da técnica utilizada por Lima (LIMA, 2003) que consiste em se incubar e m plataforma de agitação (150 rpm) à $30^{\circ} \mathrm{C} 1 \mathrm{~mL}$ de um inóculo das comunidades bacterias, em $29 \mathrm{~mL}$ dos meios de culturas a serem testados contendo a concentração de RRLO mais próxima da CIM. O crescimento microbiano foi avaliado por contagem padrão em placas em intervalos de 10 horas até 60 horas. 0 inóculo foi 
preparado em duplicata incubando-se as comunidades bacterianas obtidas em caldo LB, por $24 \mathrm{~h}$, à $30^{\circ} \mathrm{C}$ tendo sua densidade ajustada para $1,5 \times 10^{8} \mathrm{UFC} / \mathrm{mL}$.

Após a determinação da CIM e avaliação do crescimento microbiano em contato com os RRLO foram realizados os ensaios de biodegradação. Para a realização destes ensaios foram preparados inóculos com as comunidades bacterianas, incubando-se em plataforma de agitação (150 rpm) à $30^{\circ} \mathrm{C}, 1 \mathrm{~mL}$ das culturas em meio mineral acrescido de 1000 ppm de TBP, acetato de etila e dodecano. Este último, apesar de não estar pre sente nas amostras analisadas, foi estudado nesta etapa por ser conhecido solvente para o TBP no processo PUREX, havendo, por isso, possibilidade de estar presente nas outras amostras de RRLO. Com a obtenção de uma população de microrganismos igual à $3 \times 10^{8}$ $\mathrm{UFC} / \mathrm{mL}$ todas as culturas foram centrifugadas a $3.000 \mathrm{rpm}$ durante 20 minutos, o "pellet" obtido foi lavado duas vezes com solução salina $0,85 \%$. Em seguida as células foram ressuspendidas na mesma solução para obtenção de uma suspensão bacteriana contendo $1,5 \times 10^{8} \mathrm{UFC} / \mathrm{mL}$, alíquotas de $1,0 \mathrm{~mL}$ desta suspensão foram distribuídas em frascos previamente lavados com acetona (Merck $®$ ), contendo $8 \mathrm{~mL}$ dos meios de culturas a serem testado e $1 \mathrm{~mL}$ de uma solução padrão de TBP, dodecano e acetato de etila obtendo -se uma concentração final de $5 \mathrm{mg} / \mathrm{mL}$ (5000 ppm) de cada composto na cultura bacteriana. As comunidades foram então, incubadas à temperatura de $30^{\circ} \mathrm{C} \mathrm{em}$ plataforma de agitação (150 rpm) durante 96, 240, 480 e 720 horas. Como controles, foram preparados frascos contendo inóculos inativados por autoclavação. Todos os experimentos foram realizados em duplicatas.

Decorrido o tempo de incubação, a reação de degradação foi interrompida por autoclavação dos frascos, sendo em seguida adicionados 1000 ppm de octano como padrão interno e $5 \mathrm{~mL}$ de diclorometano para extração líquido líquido dos compostos orgânicos. Os frascos foram homogeneizados em um agitador mecânico tipo vórtex (Phoenix®) por 5 min. Após a homogeneização, foi retirado $0,2 \mu \mathrm{L}$ da fase correspondente ao dicl orometano utilizando uma seringa de vidro Hamilton (previamente lavada 25 vezes com acetona e também lavada 25 vezes entre cada aplicação), e injetado a $250^{\circ} \mathrm{C}$ no cromatógrafo Agilent $6890 \mathrm{~N}$ do Laboratório de Remediação de Solos da Universidade Cruzeiro do Sul, a separação dos compostos foi feita com uma coluna DB -XLB da J\&E Scientific ( $30 \mathrm{~m}$, d.i. $0,25 \mathrm{~mm}$ e filme de $0,25 \mathrm{um})$ utilizando como gás de arraste o hélio (1,3 
$\mathrm{mL} / \mathrm{min}$ ). A temperatura inicial da coluna foi mantida por $5 \mathrm{~min}$ a $30^{\circ} \mathrm{C} \mathrm{e}$, em seguida, aumentada até $180^{\circ} \mathrm{C}\left(10^{\circ} \mathrm{C} / \mathrm{min}\right)$ por $1 \mathrm{~min}$, e, então, novamente aumentada até $230^{\circ} \mathrm{C}\left(10^{\circ} \mathrm{C} / \mathrm{min}\right)$. Esta ú ltima foi mantida por 3 min para garantir a saída de todos os compostos. As concentrações dos compostos orgânicos obtidas nas análises foram calculadas em função do padrão interno recuperado (octano).

Os meios de cultura utilizados na determinação da CIM, avaliação do crescimento microbiano e nos ensaios de biodegradação foram os meios mínimo D e o meio PAS $\left(\mathrm{NH}_{4}\right) 2 \mathrm{SO}_{4}$ 1,0g/L, $\mathrm{KH}_{2} \mathrm{PO} 4$ 0,2g/L, $\mathrm{K}_{2} \mathrm{HPO} 4$ 1,6g/L, $\mathrm{MgSO}_{4} .7 \mathrm{H}_{2} \mathrm{O}$ $0,2 \mathrm{~g} / \mathrm{L}, \mathrm{FeSO}_{4} .7 \mathrm{H} 2 \mathrm{O} 0,01 \mathrm{~g} / \mathrm{L}, \mathrm{CaCl}_{2} \cdot 2 \mathrm{H}_{2} \mathrm{O} \quad 0,02 \mathrm{~g} / \mathrm{L}, \mathrm{MnSO}_{4} \cdot 2 \mathrm{H}_{2} \mathrm{O} 0,01 \mathrm{~g} / \mathrm{L}$. As medidas de densidade dos microrganismos foram realizadas comparando -se a turvação dos meios de cultura com a escala padrão de Macfarland (Probac $®)$ ).

\subsection{Biodegradação dos RRLO}

Nesta etapa foram realizados ensaios para a avaliação da degradação dos compostos orgânicos presentes nos RRLO, pelas comunidades bacterianas Bia, Bia Lago e São Sebastião.

Foram utilizados os RRLO 80 e 85 in natura e destilados. Os rejeitos destilados foram avaliados nesta etapa, pois em alguns casos a destilação pode ser empregada para a recuperação dos compostos orgânicos voláteis presentes nos RRLO com conseqüente redução de volume. Porém, o rejeito resultante da destilação ainda contém TBP o qual necessita de tratamento.

A destilação dos RRLO foi realizada pelo processo de batelada no qual 100 $\mathrm{mL}$ dos rejeitos 80 e 85 foram destilados durante uma hora a $90^{\circ} \mathrm{C}$. A destilação foi executada em uma capela de exaustão de ga ses utilizando um aparelho de destilação consistindo em: manta aquecedora com controle de temperatura, balão de $500 \mathrm{~mL}$, coluna de vigreux de $40 \mathrm{~cm}$, refrigerador de refluxo de $35 \mathrm{~cm}$, e frasco receptor de $100 \mathrm{~mL}$ (FIG.9).

A CIM dos destilados dos rejeitos 80 e 85 também foi avaliada ne sta etapa, por ser um fator determinante para o crescimento das comunidades. O ensaio para se determinar a CIM foi realizado nas mesmas condições descritas na segunda etapa, para a determinação da CIM do s rejeitos in natura. 
Os ensaios de biodegradação dos compostos org ânicos dos rejeitos $80 \mathrm{e}$ 85 in natura e destilados bem como a quantificação da degradação do TBP e do acetato de etila presente nas amostras, foram realizados nas mesmas condições descritas na segunda etapa (FIG. 10), porém somente com o meio mínimo PAS, por conter a menor concentração de fosfato inorgânico $(9,2 \mathrm{mM})$ quando comparado ao meio mínimo D (32,6 mM ). De acordo com TOMAS \& MACASKE (1997) quantidades superiores a $10 \mathrm{~m} \mathrm{M}$ podem reduzir a biodegradação do TBP.

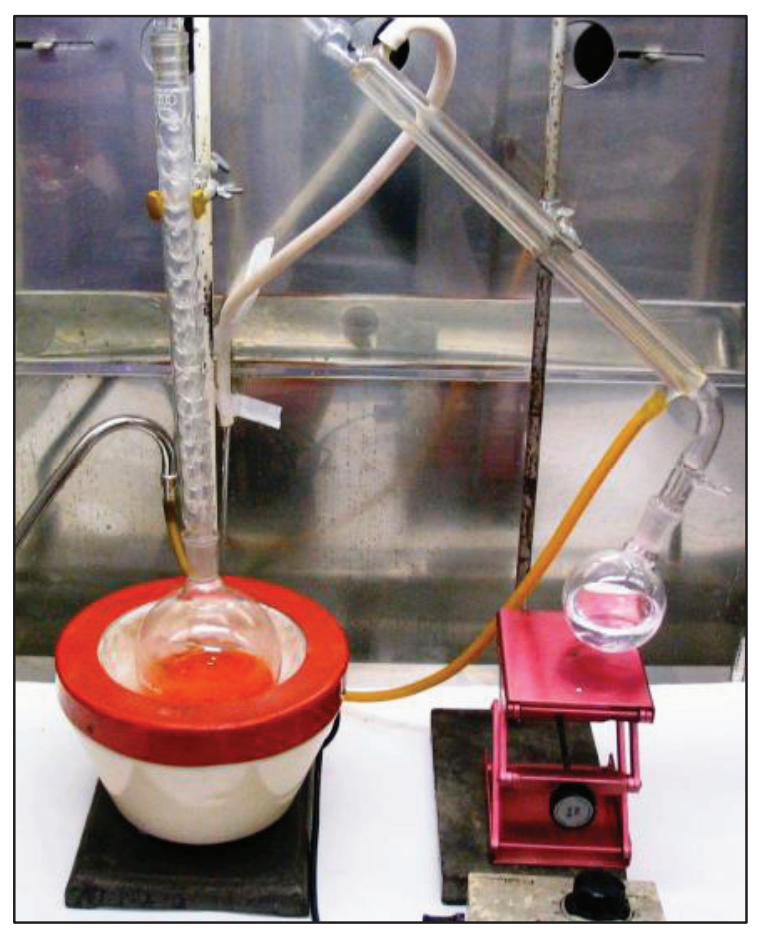

FIGURA 9: Aparato utilizado para destilação dos RRLO 


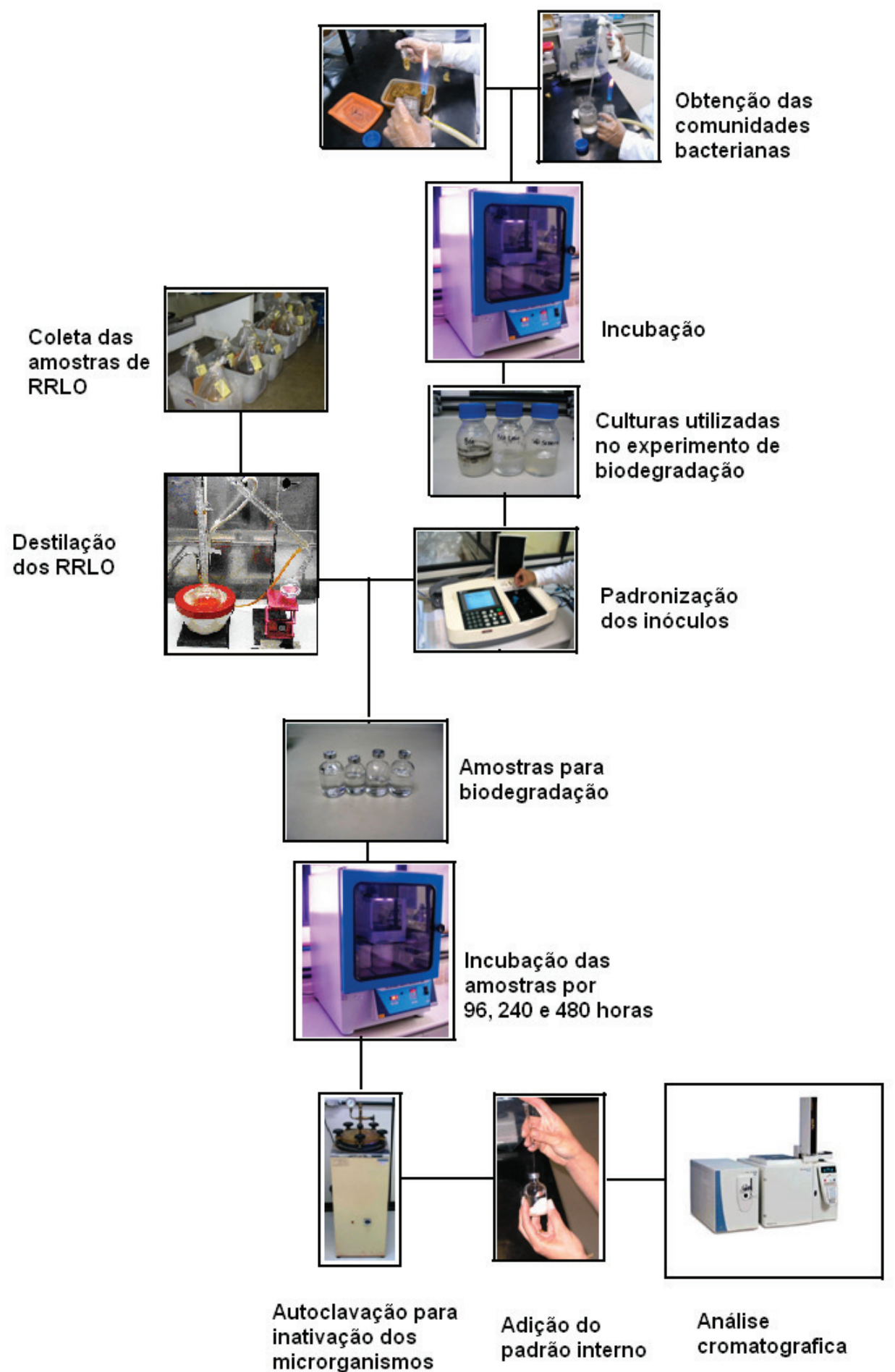

FIGURA 10: Representação esquemática da metodologia utilizada na biodegradação dos RRLO 


\subsection{Gerenciamento de rejeitos}

Os principais rejeitos radioativos gerados nos experimentos foram os líquidos (meios de cultura), os frascos utilizados nos experimentos de biodegradação, as ponteiras e os pap éis absorventes. As amostras líquidas receberam destinação adequada, conforme orientação da Supervisão de Proteção Radiológica do IPEN. Os frascos de vidro utilizados foram, descontaminados com solução de hipoclorito e detergente, e antes da reutilização, foram monitorados no espectrômetro gama. A descontaminação foi realizada em uma pia com esgoto sanitário, conectado a um tanque de retenção. Os outros materiais foram monitorados. Os que apresentaram contaminação foram descartados como rejeito radioativo e aqueles que não apresentaram contaminação foram liberados como lixo comum. 


\section{RESULTADOS E DISCUSSÃO}

\subsection{Caracterização dos Rejeitos}

As análises qualitativas das amostras 80 e 85 estão representadas nas FIG. 11 e 12 respectivamente.

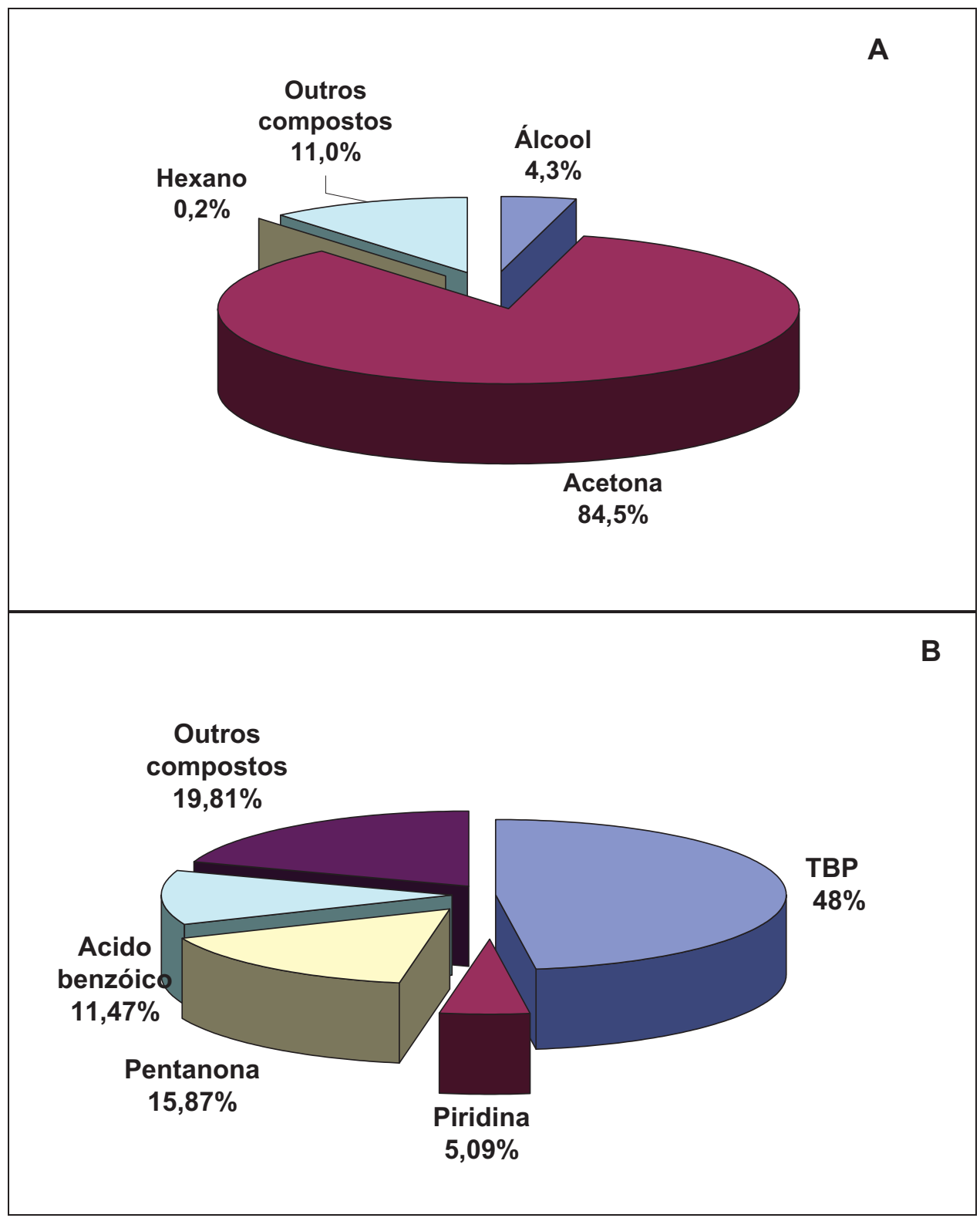

FIGURA 11: Análises qualitativas dos compostos orgânicos presentes na embalagem 80: (A) amostras analisadas por CG "HeadSpace" (B) amostras analisadas por CG injeção direta 


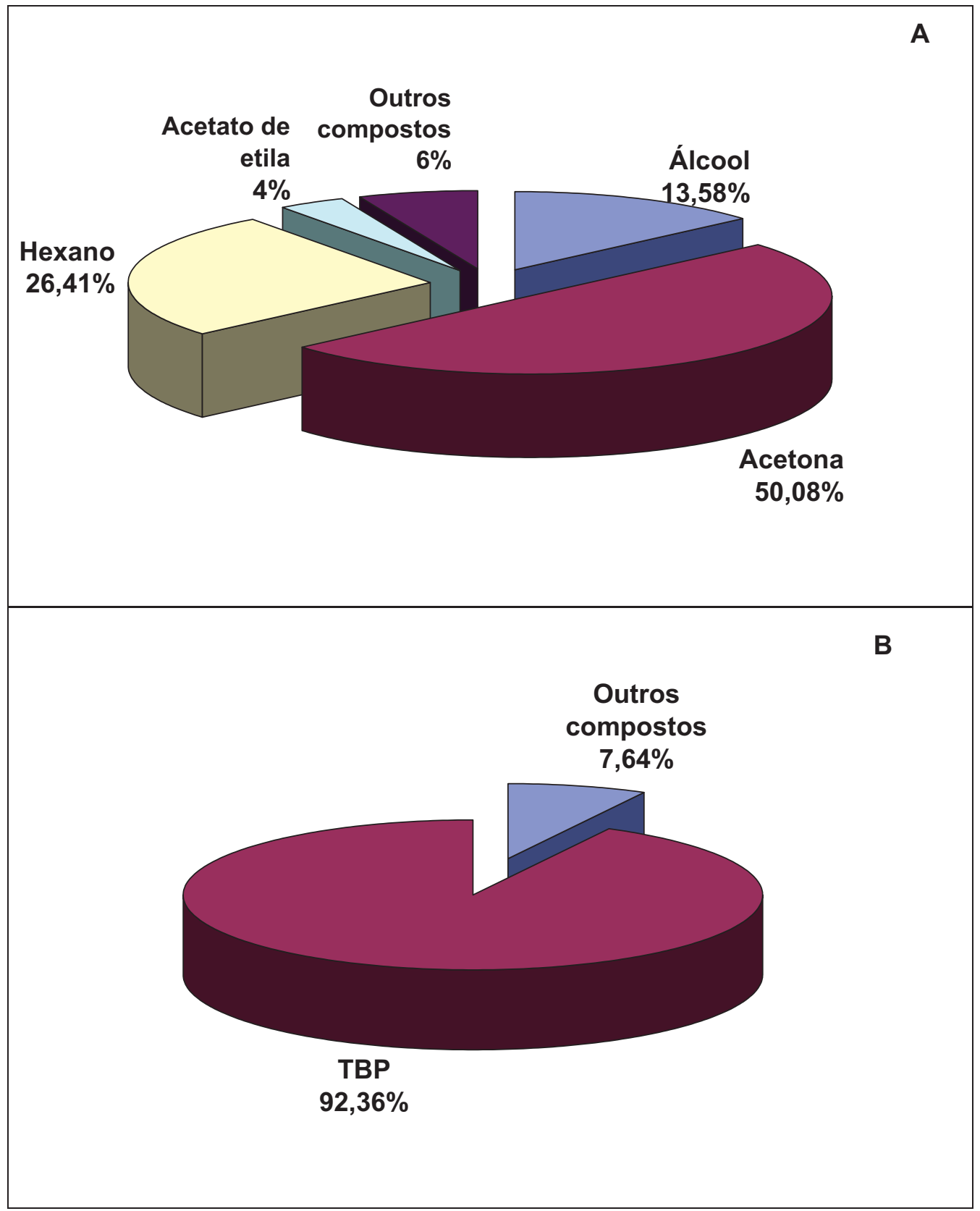

FIGURA 12: Análises qualitativas dos compostos orgânicos presentes na embalagem 85: (A) amostras analisadas por CG "HeadSpace" (B) amostras analisadas por CG injeção direta

Com estes resultados pode-se afirmar que a composição orgânica dos RRLO é uma mistura de etanol, acetona, acetato de etila, hexano, piridina e TBP, sendo majoritariamente composta por TBP e acetona. 


\subsection{Obtenção e estudo das comunidades microbianas .}

\subsubsection{Avaliação da contaminação por microrganismos .}

Os ensaios de contagem padrão em placa não revelaram microrganismos mesófilos neutrófilos e mesófilos acidófilos em nenhuma amostra de RRLO armazenados no LRR.

Estes resultados indicaram que os RRLO, na forma em que se encontram estocados, não são um ambiente propício para o crescimen to de microorganismos, levando à necessidade de se obter e adaptar comunidades bacterianas de outros ambientes para a realização da biodegradação dos compostos orgânicos.

\subsubsection{Determinação da concentração inibitória mínima (CIM) dos Rejeitos Radioativos Líquidos Orgânicos (RRLO).}

As CIM das amostras 80 e 85 foram avaliadas para se determinar a concentração máxima das amostras no meio com a qual as comunidades bacterianas conseguem crescer. As concentrações das amostras 80 e 85 capaz es de inibir o crescimento foram idênticas, situando-se entre $32 \%$ e $50 \%$ para a comunidade Bia e 16\% e 32\% para as comunidades Bia Lago e São Sebastião.

\subsubsection{Curvas de crescimento}

As representações gráficas dos resultados de crescimento das comunidades bacterianas Bia, Bia Lago e São Sebastião em meios de cultura contendo diferentes concentrações dos RRLO estão apresentadas nas figuras de 13 à 24. O crescimento das comunidades bacterianas em meio mínimo $D$ e meio PAS contendo diferentes concentrações dos RRLO 80 e 85 em função d o tempo, estão apresentadas nas FIG. de 13 à 20. Observa-se a estabilização do número de microrganismos ao longo do tempo, não existindo diferença significativa entre os cultivos, exceto na comunidade bacteriana Bia cultivada em meio mínimo D com $32 \%$ e $16 \%$ do RRLO 80 (FIG. 13). Neste caso, o crescimento microbiano foi superior a $10^{3}$. O desvio padrão observado em todas as medidas foi inferior a $5 \%$. Nas FIG. de 21 à 24 estão representados os crescimentos das comunidades bacterianas Bia, Bia Lago e São Sebas tião em caldo LB, contendo diferentes 
concentrações dos RRLO 80 e 85 . O crescimento das comunidades bacterianas neste meio foi superior ao observado no meio mínimo $D$ e meio PAS.

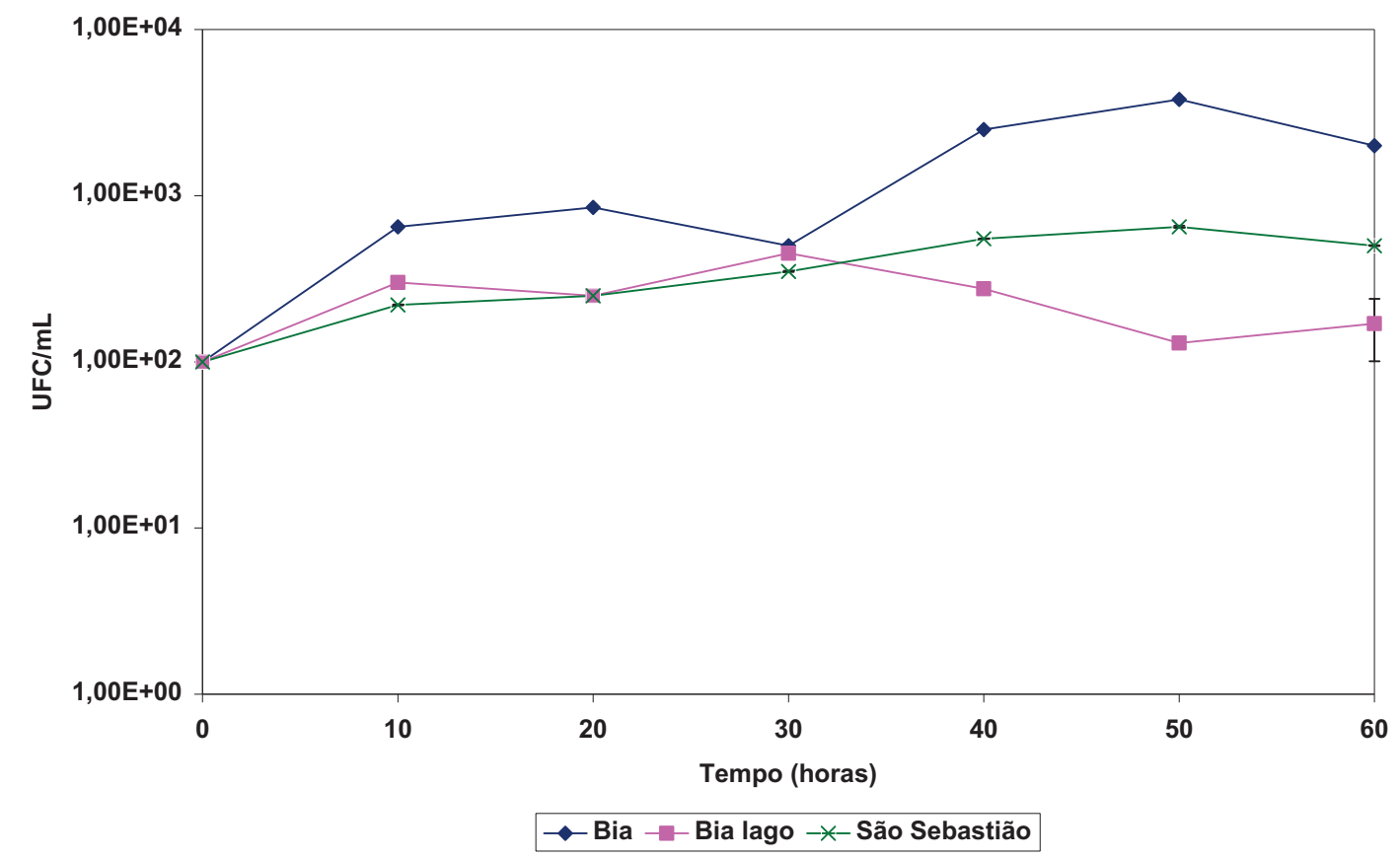

FIGURA 13: Representa o crescimento em meio mínimo $D$ das comunidades Bia cultivadas com 32\% e Bia lago e São Sebastião com 16\% de RRLO 80.

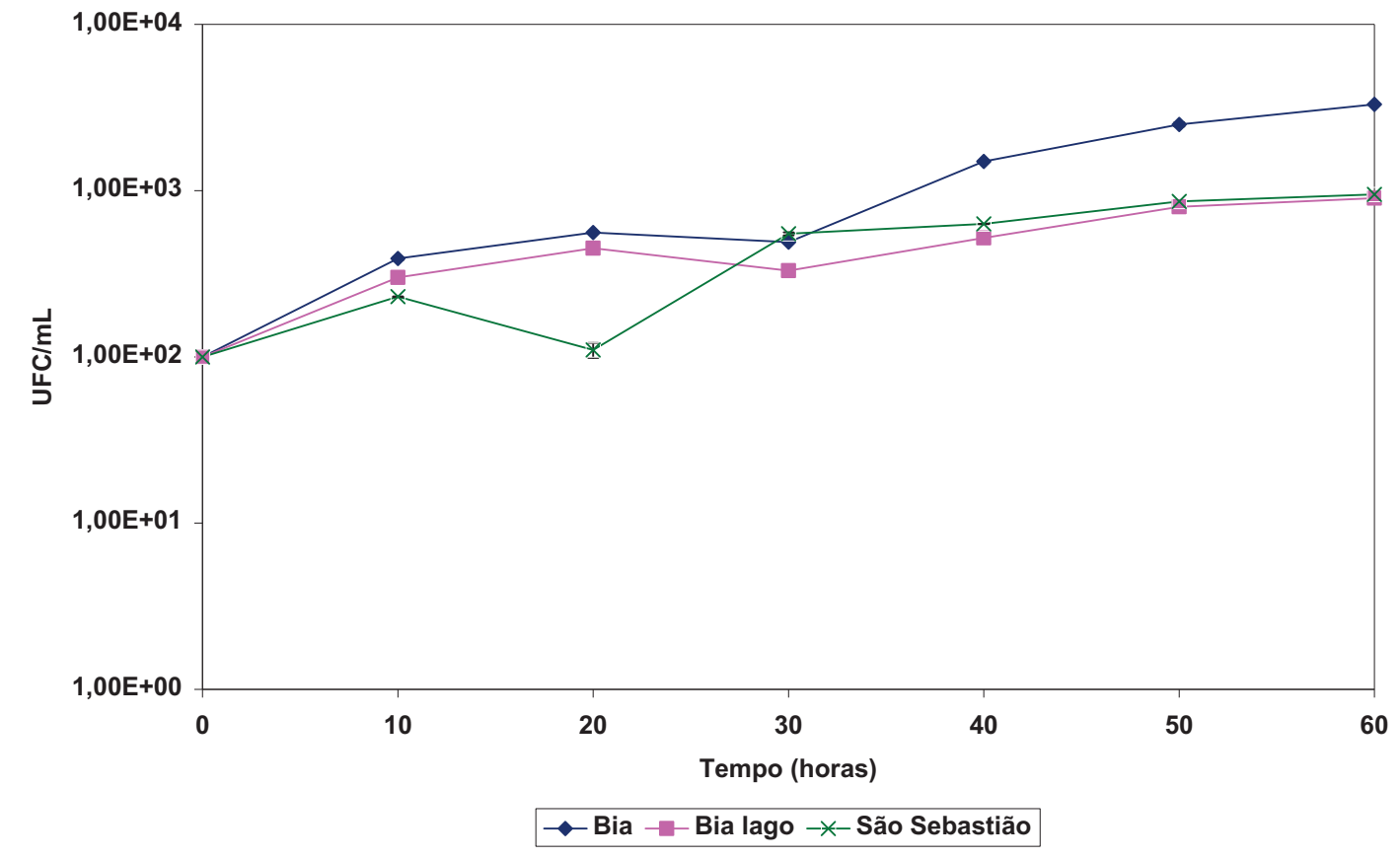

FIGURA 14: Representa o crescimento em meio mínimo D das comunidades Bia cultivadas com 16\% e Bia lago e São Sebastião com 8\% de RRLO 80. 


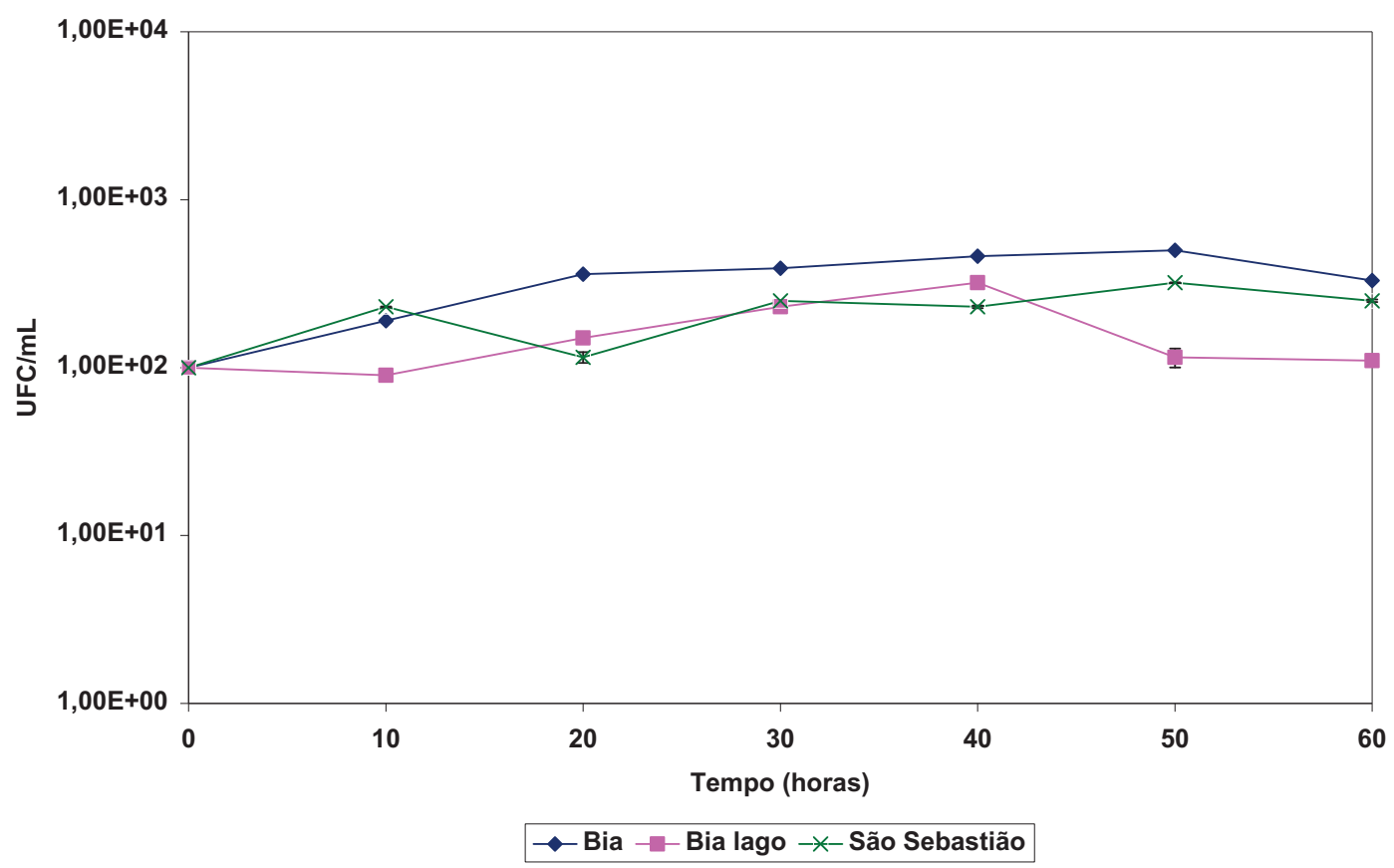

FIGURA 15: Representa o crescimento em meio mínimo D das comunidades Bia cultivadas com 32\% e Bia lago e São Sebastião com 16\% de RRLO 85.

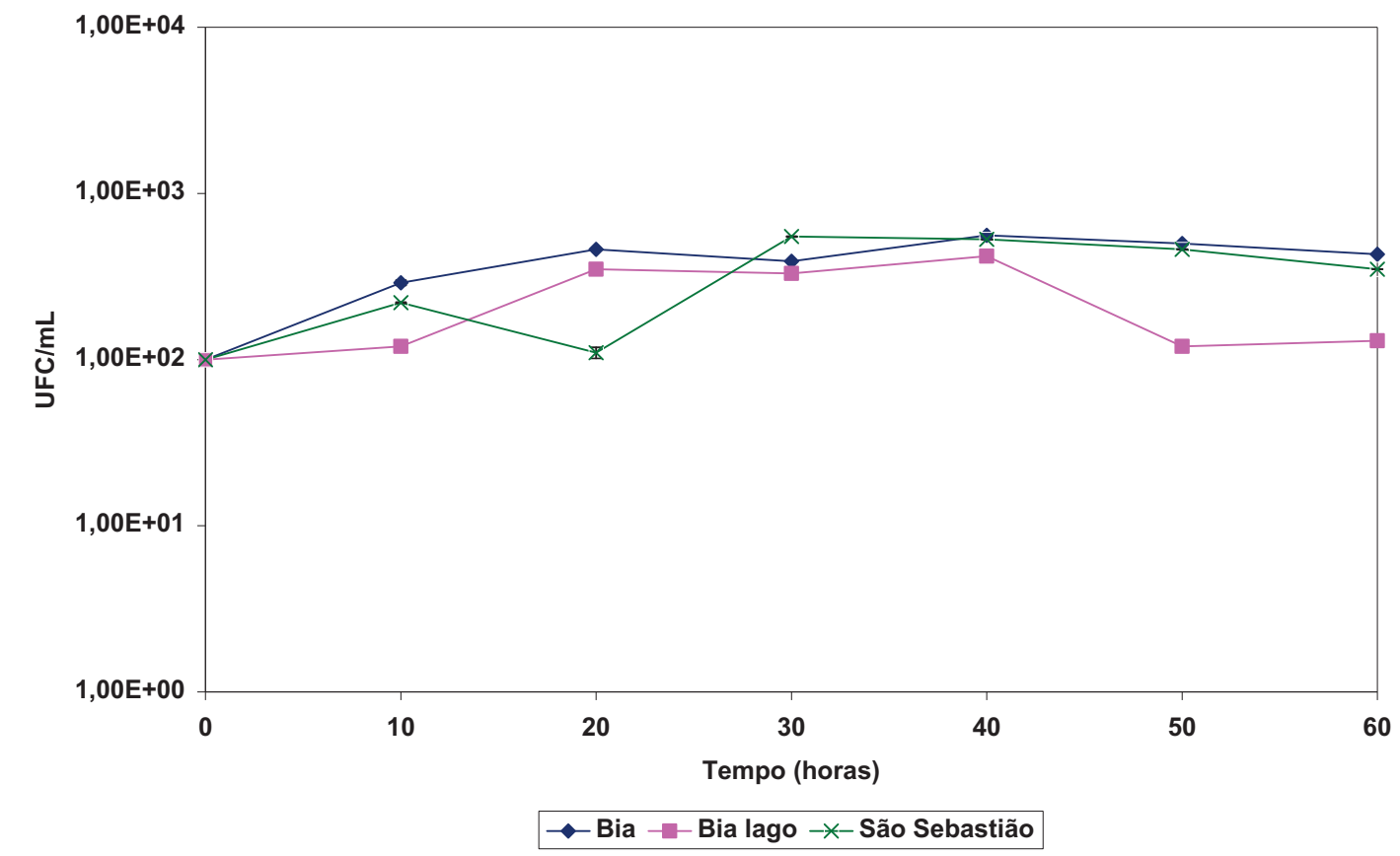

FIGURA 16: Representa o crescimento em meio mínimo $D$ das comunidades Bia cultivadas com 16\% e Bia lago e São Sebastião com 8\% de RRLO 85. 


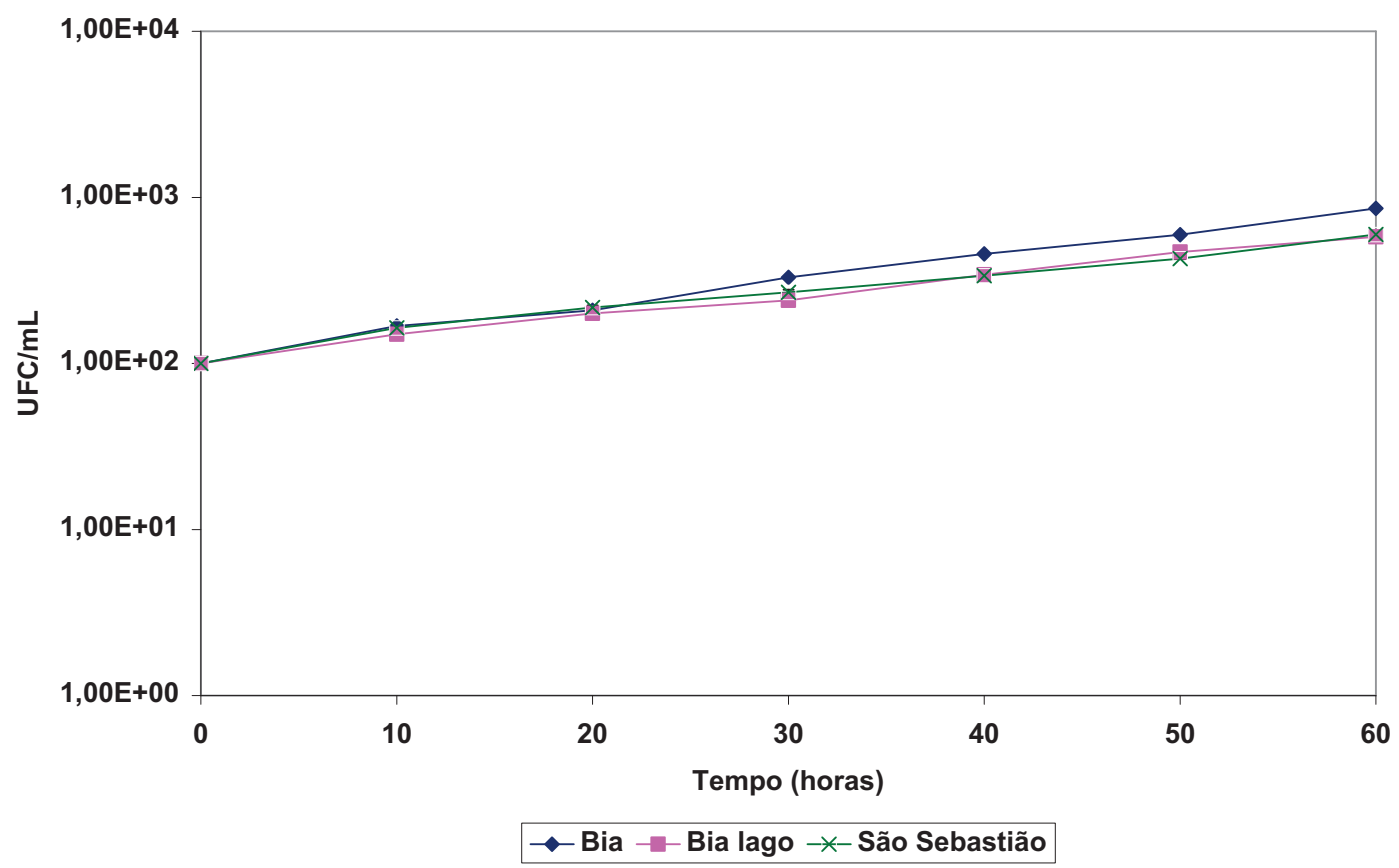

FIGURA 17: Representa o crescimento em meio mínimo PAS das comunidades Bia cultivadas com 32\% e Bia lago e São Sebastião com 16\% de RRLO 80.

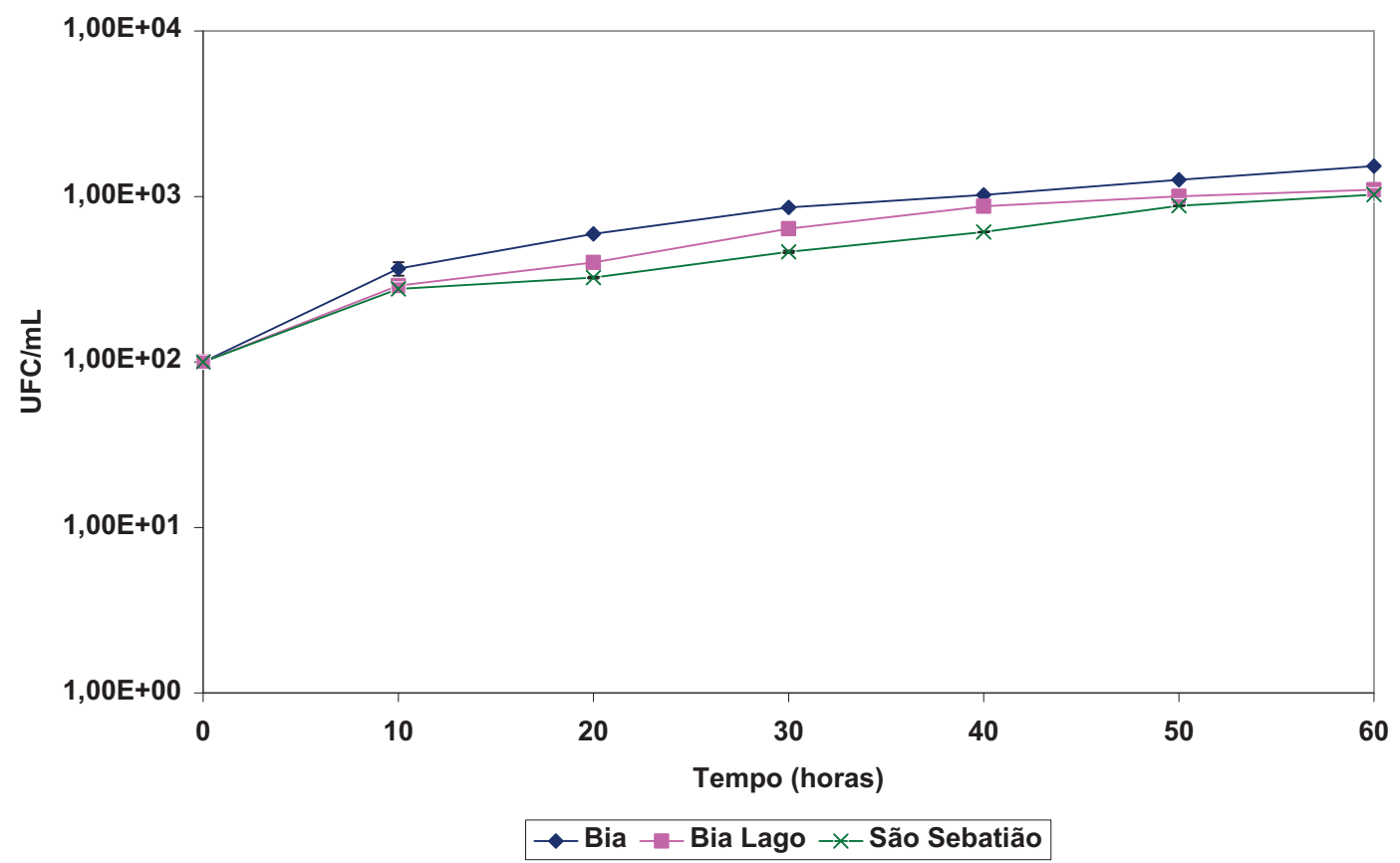

FIGURA 18: Representa o crescimento em meio mínimo PAS das comunidades Bia cultivadas com 16\% e Bia lago e São Sebastião com 8\% de RRLO 80. 


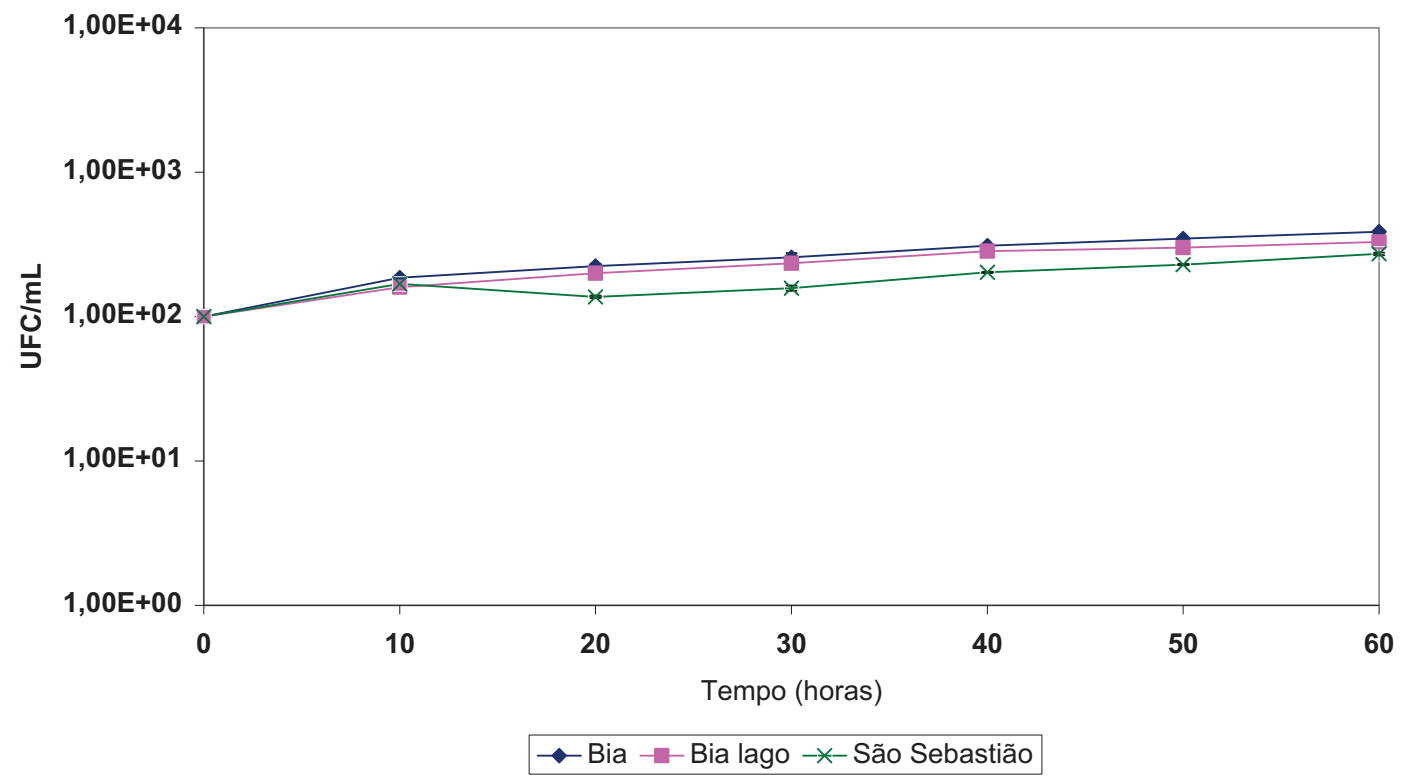

FIGURA 19: Representa o crescimento em meio mínimo PAS das comunidades Bia cultivadas com 32\% e Bia lago e São Sebastião com 16\% de RRLO 85.

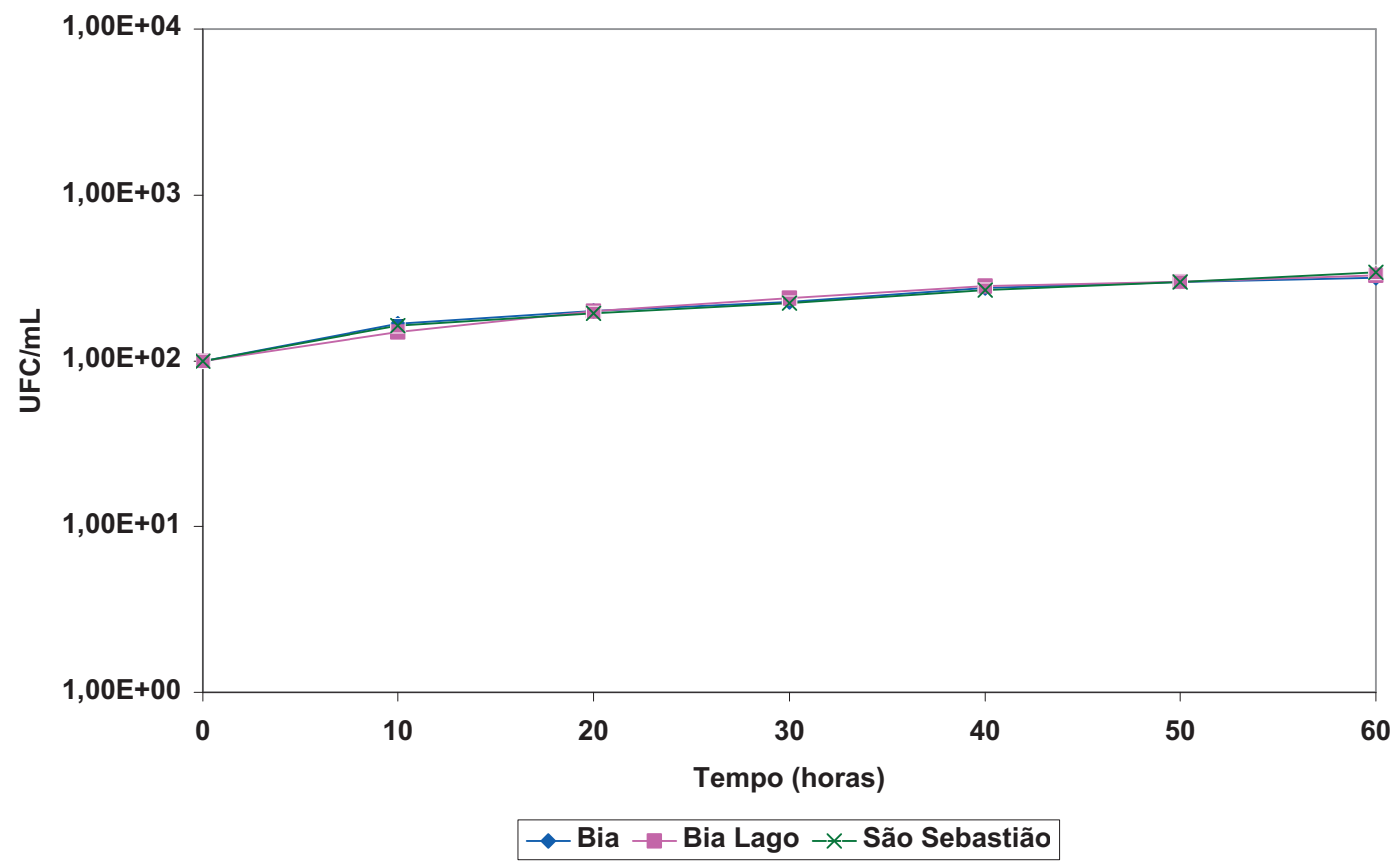

FIGURA 20: Representa o crescimento meio mínimo PAS das comunidades Bia em cultivadas com 16\% e Bia lago e São Sebastião com 8\% de RRLO 85. 


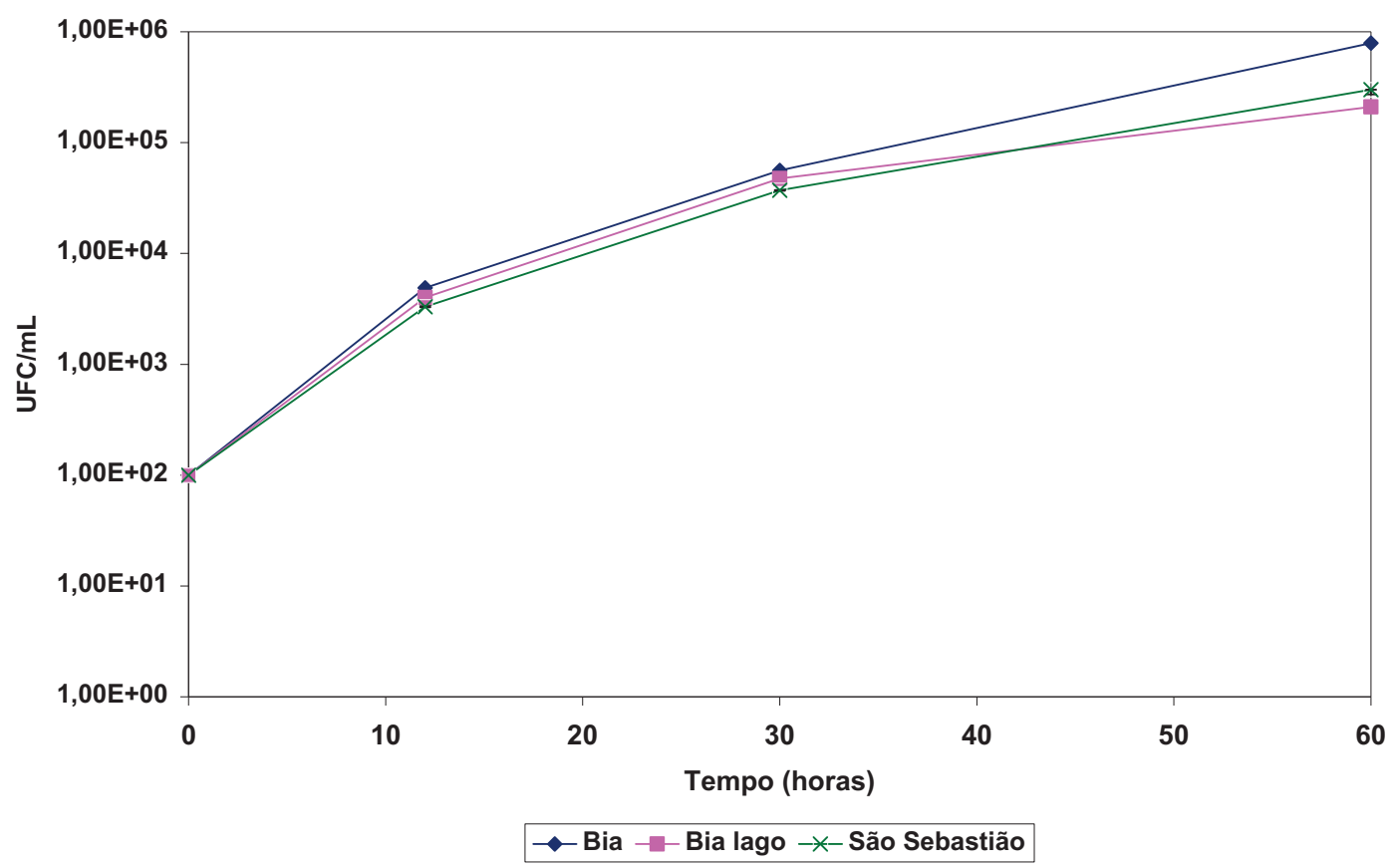

FIGURA 21: Representa o crescimento em caldo LB das comunidades Bia cultivadas com 32\% e Bia lago e São Sebastião com 16\% de RRLO 80.

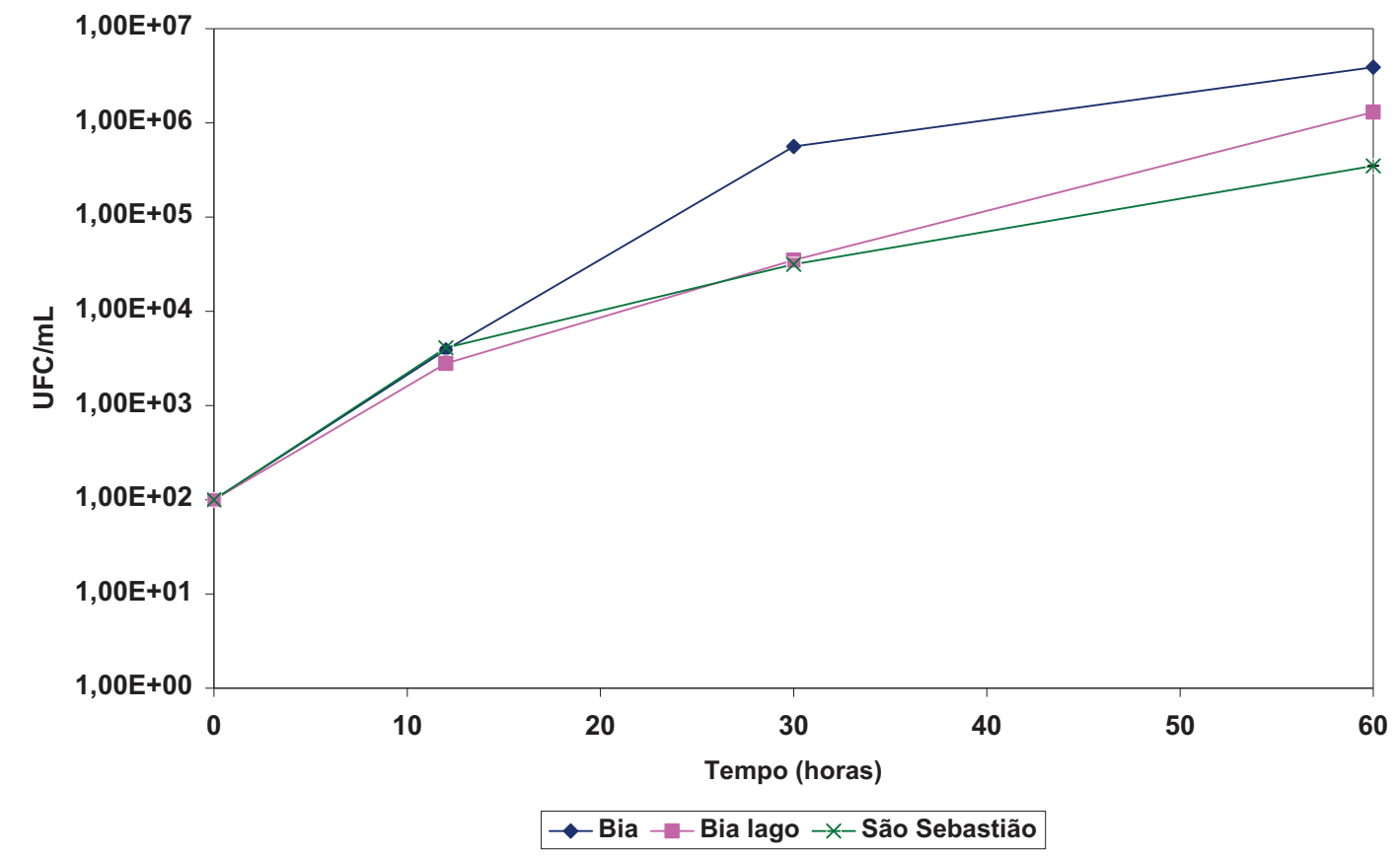

FIGURA 22: Representa o crescimento em caldo LB das comunidades Bia cultivadas com 16\% e Bia lago e São Sebastião com 8\% de RRLO 80. 


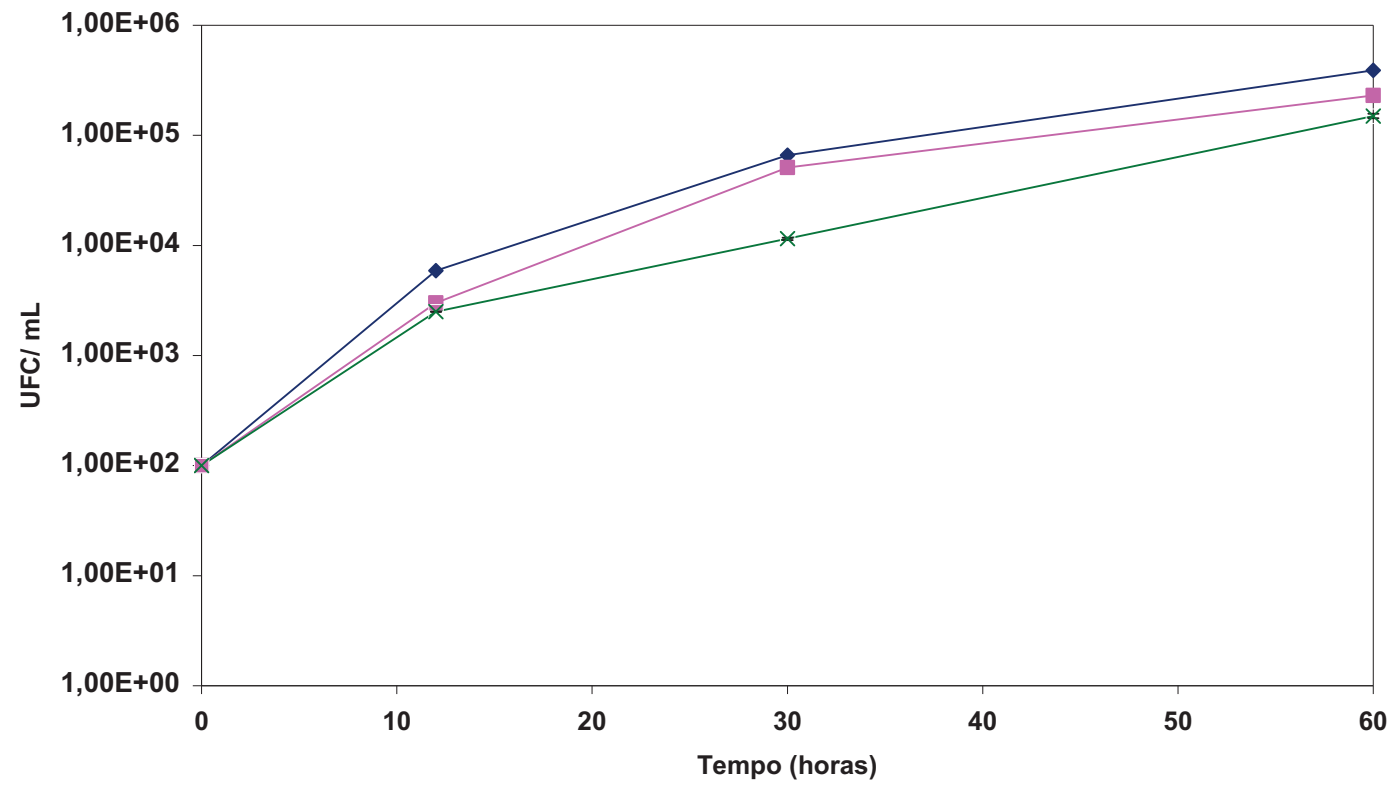

•-Bia $\rightarrow$ - Bia lago $-\star$ São Sebastião

FIGURA 23: Representa o crescimento em caldo LB das comunidades Bia cultivadas com 32\% e Bia lago e São Sebastião com 16\% de RRLO 85.

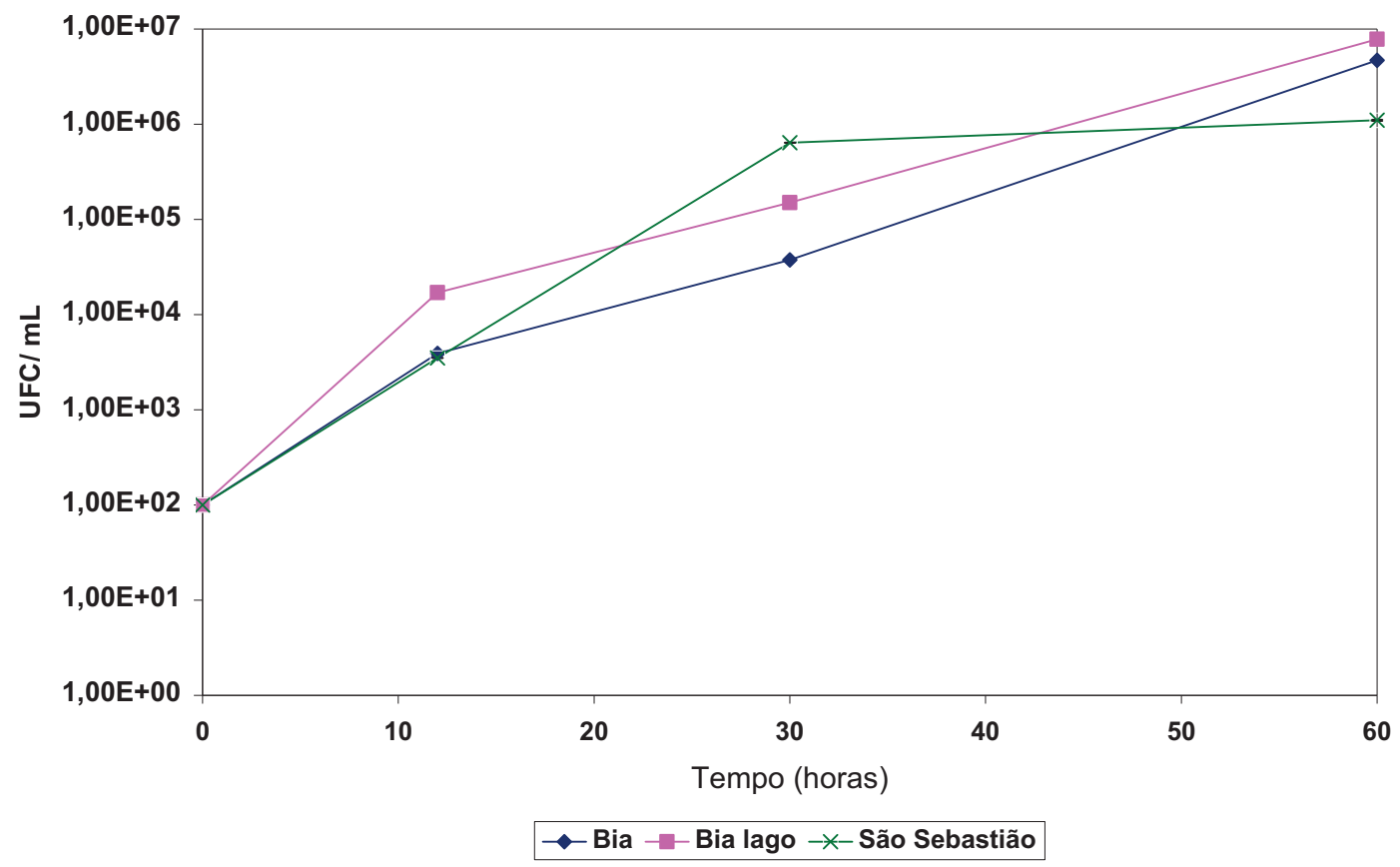

FIGURA 24: Representa o crescimento em caldo LB das comunidades Bia cultivadas com 16\% e Bia lago e São Sebastião com 8\% de RRLO 85. 


\subsubsection{Experimentos de biodegradação dos compostos orgânicos presentes} nos RRLO.

Os resultados obtidos nos experimentos de biodegradação do acetato de etila, dodecano e TBP, pelas comunidades bacterianas estão apresentados nas FIG. de 25 à 30. Os resultados foram comparados com a concentração inicial, aplicando-se o teste t de Student, com nível de significância de 95\%.

\subsubsection{Biodegradação do acetato de etila}

Pode-se observar nas FIG. 25 e 26, uma diminuição da concentração de acetato de etila em função do tempo, em meio mineral e em meio PAS. As degradações máximas observadas em meio mineral foram 25,08\%, 29,51\%, $25,31 \%$ e em meio PAS 31,26\%, 29,70\%, 18,77\% par a Bia, Bia Lago e São Sebastião respectivamente.

Estes resultados são semelhantes aos obtidos por DORONINA et al, (2006) no estudo de biodegradação de acetato de etila por uma cepa de Pseudomonas esterophilus, que obteve uma taxa de degradação máxima de $26,1 \%$ acetato de etila.

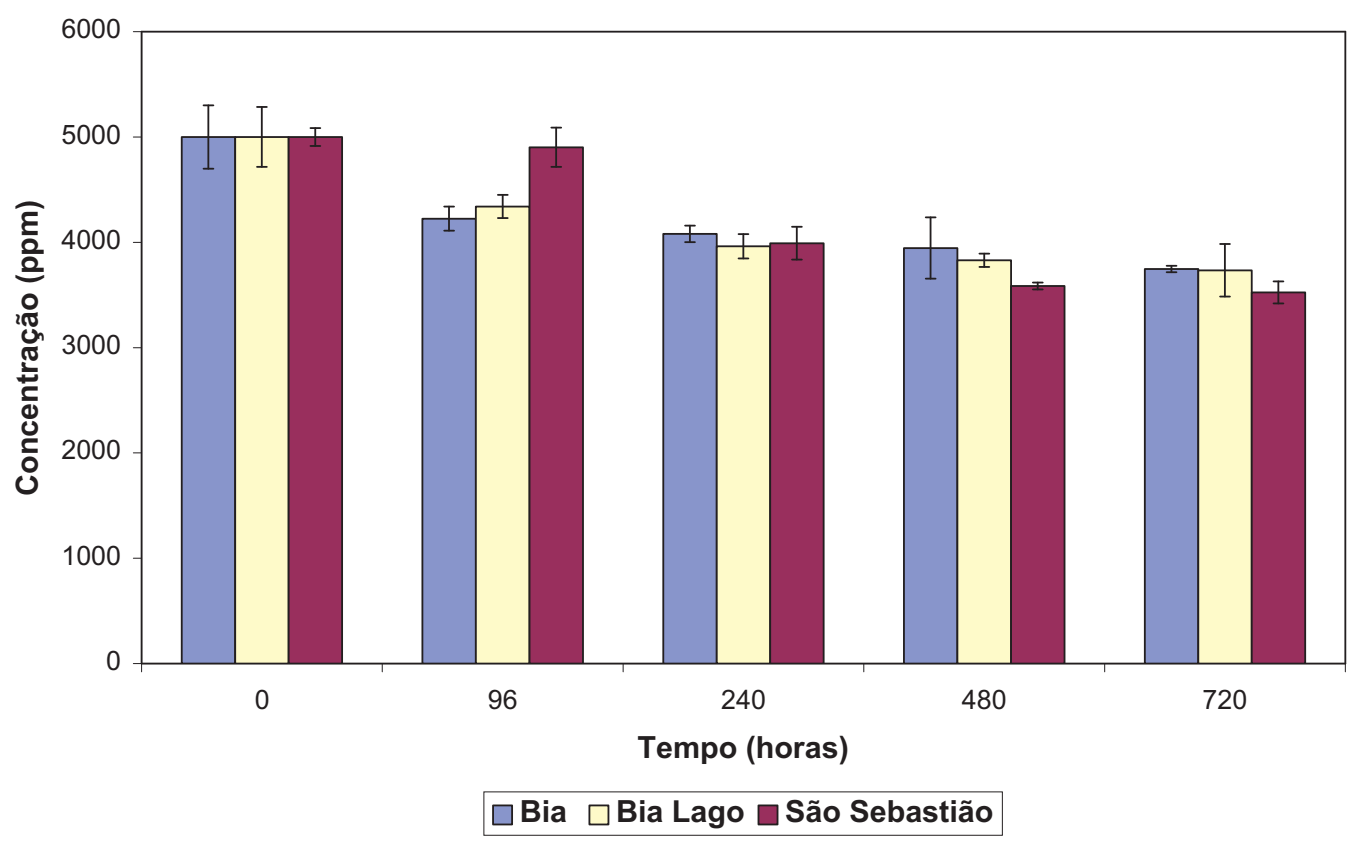

FIGURA 25: Biodegradação de Acetato de etila em meio mínimo D por diferentes comunidades bacterianas ( $\left.{ }^{*} \alpha<0,05\right)$. 


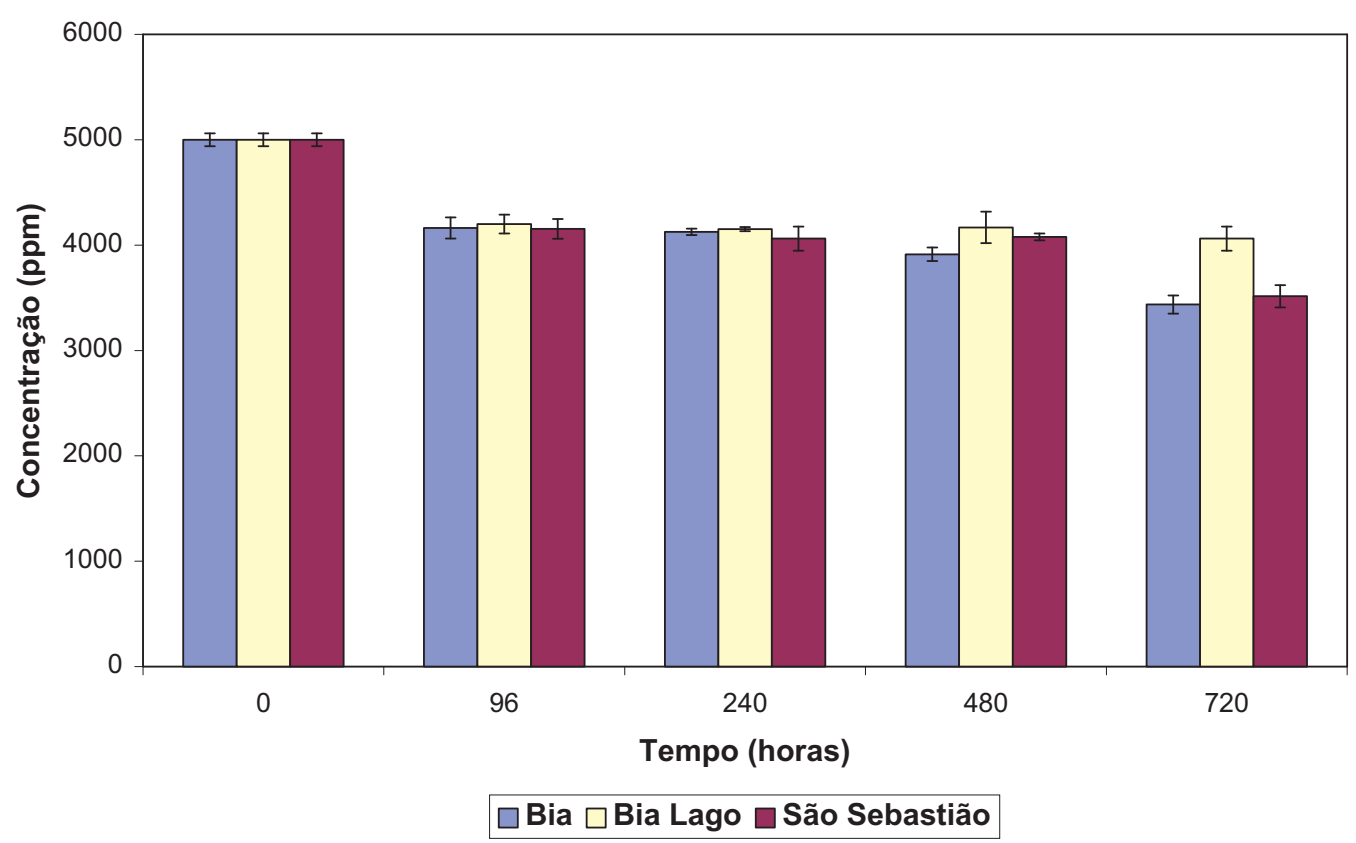

FIGURA 26: Biodegradação de acetato de etila em meio PAS por diferentes comunidades bacterianas $\left({ }^{*} \alpha<0,05\right)$.

TABELA 2: Degradação de Acetato de etila em função do tempo, pelos consórcios bacterianos Bia, Bia Lago e São Sebastião, cultivados em meio mínimo D e meio PAS.

\begin{tabular}{|c|c|c|c|c|c|}
\hline \multirow{2}{*}{$\begin{array}{c}\text { Meios } \\
\text { de } \\
\text { cultura }\end{array}$} & \multirow{2}{*}{$\begin{array}{l}\text { Consórcios } \\
\text { Bacterianos }\end{array}$} & \multicolumn{4}{|c|}{ Média \pm Desvio-padrão ppm (\% redução) } \\
\hline & & $96 \mathrm{~h}$ & $240 \mathrm{~h}$ & $480 \mathrm{~h}$ & $720 \mathrm{~h}$ \\
\hline \multirow{3}{*}{$\begin{array}{l}\text { Meio } \\
\text { mínimo } \\
\text { D }\end{array}$} & Bia & $\begin{array}{c}4224,6 \pm 100,4 \\
(15,5 \%)\end{array}$ & $\begin{array}{c}4080,0 \pm 30,7 \\
(18,4 \%)\end{array}$ & $\begin{array}{c}3945,9 \pm 64,6 \\
(21,1 \%)\end{array}$ & $\begin{array}{c}3746,1 \pm 86,0 \\
(25,1 \%)\end{array}$ \\
\hline & Bia Lago & $\begin{array}{c}4340,3 \pm 88,8 \\
(13,2 \%)\end{array}$ & $\begin{array}{c}3962,5 \pm 19,5 \\
(20,8 \%)\end{array}$ & $\begin{array}{c}3828,6 \pm 149,0 \\
(23,4 \%)\end{array}$ & $\begin{array}{c}3734,4 \pm 114,39 \\
(25,3 \%)\end{array}$ \\
\hline & $\begin{array}{l}\text { São } \\
\text { Sebastião }\end{array}$ & $\begin{array}{c}4902,0 \pm 93,7 \\
(2,0 \%)\end{array}$ & $\begin{array}{c}3991,2 \pm 114,4 \\
(20,2 \%)\end{array}$ & $\begin{array}{c}3585,7 \pm 33,0 \\
(28,3 \%)\end{array}$ & $\begin{array}{c}3524,7 \pm 105,4 \\
(29,5 \%)\end{array}$ \\
\hline \multirow[t]{3}{*}{$\begin{array}{l}\text { Meio } \\
\text { PAS }\end{array}$} & Bia & $\begin{array}{c}4163,7 \pm 113,6 \\
(16,7 \%)\end{array}$ & $\begin{array}{c}4126,6 \pm 77,6 \\
(17,5 \%)\end{array}$ & $\begin{array}{c}3912,7 \pm 290,7 \\
(21,7 \%)\end{array}$ & $\begin{array}{c}3436,8 \pm 31,1 \\
(31,3 \%)\end{array}$ \\
\hline & Bia Lago & $\begin{array}{c}4200,2 \pm 109,9 \\
(16,0 \%)\end{array}$ & $\begin{array}{c}4151,7 \pm 115,9 \\
(17,0 \%)\end{array}$ & $\begin{array}{c}4167,4 \pm 63,0 \\
(16,7 \%)\end{array}$ & $\begin{array}{c}4061,5 \pm 249,4 \\
(18,8 \%)\end{array}$ \\
\hline & $\begin{array}{l}\text { São } \\
\text { Sebastião }\end{array}$ & $\begin{array}{c}4154,6 \pm 186,8 \\
(16,9 \%) \\
\end{array}$ & $\begin{array}{c}4061,5 \pm 156,3 \\
(18,8 \%) \\
\end{array}$ & $\begin{array}{c}4077,4 \pm 32,8 \\
(18,5 \%) \\
\end{array}$ & $\begin{array}{c}3514,9 \pm 104,2 \\
(29,7 \%) \\
\end{array}$ \\
\hline
\end{tabular}




\subsubsection{Biodegradação do dodecano}

A degradação de dodecano pelas comunidades bacterianas cultivadas em meio mínimo D e meio PAS estão representadas pela F IG. 27 e 28 . É possível observar uma acentuada diminuição da concentração do composto nas primeiras 96h. Em 720h, as degradações máximas observad as em meio mínimo foram $84,86 \%, 90,44 \%, 87,82 \%$ e em meio PAS $91,76 \%, 90,15 \%, 86,56 \%$ para Bia, Bia Lago e São Sebastião, respectivamente.

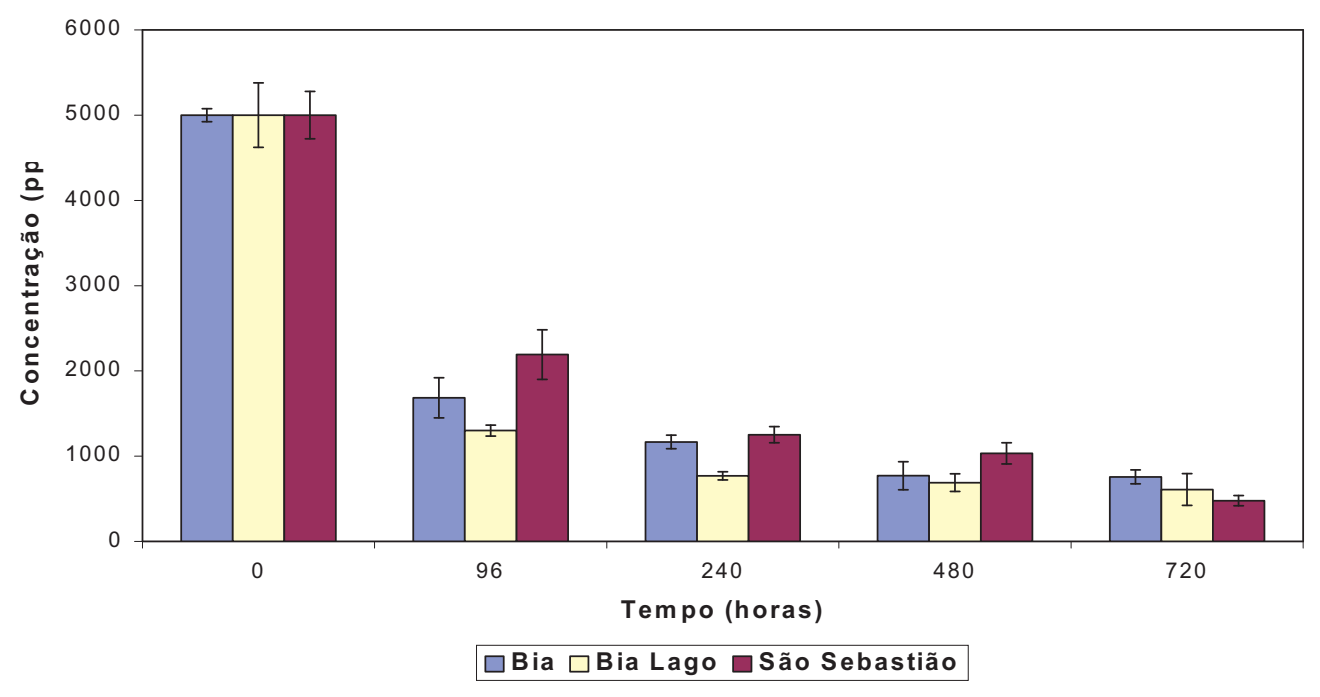

FIGURA 27: Biodegradação de dodecano por diferentes comunidades microbianas em meio mínimo $D\left({ }^{*} \alpha<0,05\right)$.

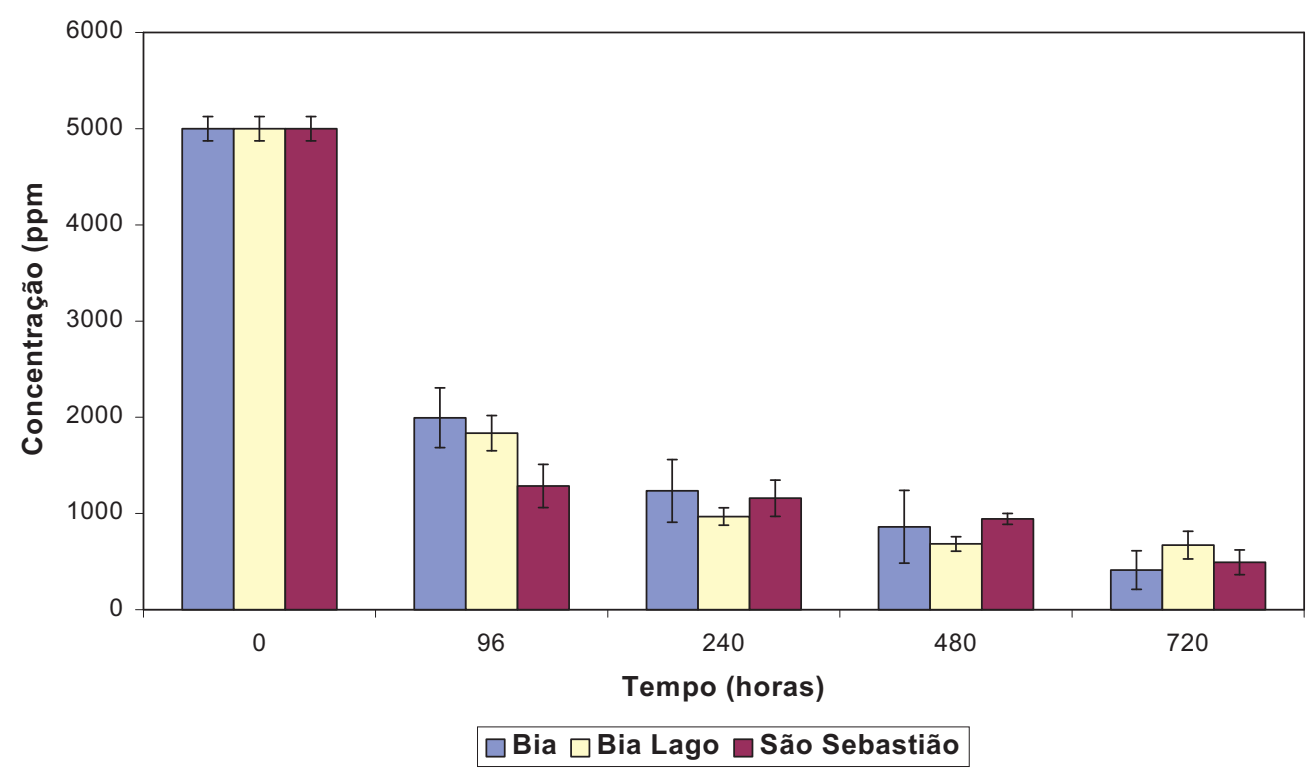

FIGURA 28: Biodegradação de dodecano por diferentes comunidades microbianas em meio PAS $\left({ }^{*} \alpha<0,05\right)$. 
TABELA 3: Degradação de Dodecano em função do tempo, pelos consórcios bacterianos Bia, Bia Lago e São Sebastião, cultivados em meio mínimo D e meio PAS.

\begin{tabular}{|c|c|c|c|c|c|}
\hline \multirow{2}{*}{$\begin{array}{l}\text { Meios } \\
\text { de } \\
\text { cultura }\end{array}$} & \multirow{2}{*}{$\begin{array}{l}\text { Consórcios } \\
\text { Bacterianos }\end{array}$} & \multicolumn{4}{|c|}{ Média \pm Desvio-padrão ppm (\% redução) } \\
\hline & & $96 \mathrm{~h}$ & 240h & 480h & 720h \\
\hline \multirow[t]{3}{*}{$\begin{array}{l}\text { Meio } \\
\text { mínimo D }\end{array}$} & Bia & $\begin{array}{c}1684,3 \pm 310,5 \\
(66,3 \%)\end{array}$ & $\begin{array}{c}1166,7 \pm 325,8 \\
(76,7 \%)\end{array}$ & $\begin{array}{c}770,7 \pm 378,5 \\
(84,6 \%)\end{array}$ & $\begin{array}{c}756,9 \pm 199,9 \\
(84,9 \%)\end{array}$ \\
\hline & Bia Lago & $\begin{array}{c}1300,2 \pm 182,9 \\
(74,0 \%)\end{array}$ & $\begin{array}{c}768,9 \pm 90,01 \\
(84,6 \%)\end{array}$ & $\begin{array}{c}689,8 \pm 75,0 \\
(86,2 \%)\end{array}$ & $\begin{array}{c}609,1 \pm 144,1 \\
(87,8 \%)\end{array}$ \\
\hline & $\begin{array}{l}\text { São } \\
\text { Sebastião }\end{array}$ & $\begin{array}{c}2191,8 \pm 224,1 \\
(56,2 \%)\end{array}$ & $\begin{array}{c}1251,8 \pm 189,0 \\
(75,0 \%)\end{array}$ & $\begin{array}{c}1033,5 \pm 56,6 \\
(79,3 \%)\end{array}$ & $\begin{array}{c}478,1 \pm 129,2 \\
(90,4 \%)\end{array}$ \\
\hline \multirow[t]{3}{*}{ Meio PAS } & Bia & $\begin{array}{c}1995,0 \pm 234,7 \\
(60,1 \%)\end{array}$ & $\begin{array}{c}1235,0 \pm 79,2 \\
(75,3 \%)\end{array}$ & $\begin{array}{c}861,3 \pm 164,4 \\
(82,8 \%)\end{array}$ & $\begin{array}{c}412,0 \pm 81,8 \\
(91,8 \%)\end{array}$ \\
\hline & Bia Lago & $\begin{array}{c}1836,0 \pm 64,3 \\
(63,3 \%)\end{array}$ & $\begin{array}{c}968,5 \pm 47,5 \\
(80,6 \%)\end{array}$ & $\begin{array}{c}683,4 \pm 103,7 \\
(86,3 \%)\end{array}$ & $\begin{array}{c}671,9 \pm 187,2 \\
(86,6 \%)\end{array}$ \\
\hline & $\begin{array}{l}\text { São } \\
\text { Sebastião }\end{array}$ & $\begin{array}{c}1285,5 \pm 290,5 \\
(74,3 \%) \\
\end{array}$ & $\begin{array}{c}1158,6 \pm 94,9 \\
(76,8 \%) \\
\end{array}$ & $\begin{array}{c}943,9 \pm 124,4 \\
(81,1 \%) \\
\end{array}$ & $\begin{array}{c}492,4 \pm 59,3 \\
(90,2 \%)\end{array}$ \\
\hline
\end{tabular}

Estes resultados são semelhantes com aos obtidos por OLIVERA (1997) em seu estudo de biodegradação de dodecano por comunidades microbianas, observou uma taxa de degradação de dodecano superior a 95\%, em $240 \mathrm{~h}$ de degradação.

\subsubsection{Biodegradação do TBP}

Os resultados da biodegradação de TBP pelas comunidades bacterianas em função do tempo em meio mínimo $D$ e meio PAS, estão apresentados nas FIG. 29 e 30 respectivamente. Exceto pela comunidade São Sebastião em meio mínimo (96h), pode-se afirmar que houve, em todos os casos, uma redução significativa da concentração de TBP em 96h. Nos casos Bia lago em meio mínimo e São Sebastião em PAS o valor da concentração praticamente se manteve constante. Nos outros casos houve uma redução ainda maior. Os maiores valores de degradação observados em meio mínimo foram 41,69\%, $46,08 \%$ e $54,70 \%$ e em meio PAS $41,02 \%, 43,69 \%$, 39,04\% para Bia, Bia Lago e São Sebastião, respectivamente. 


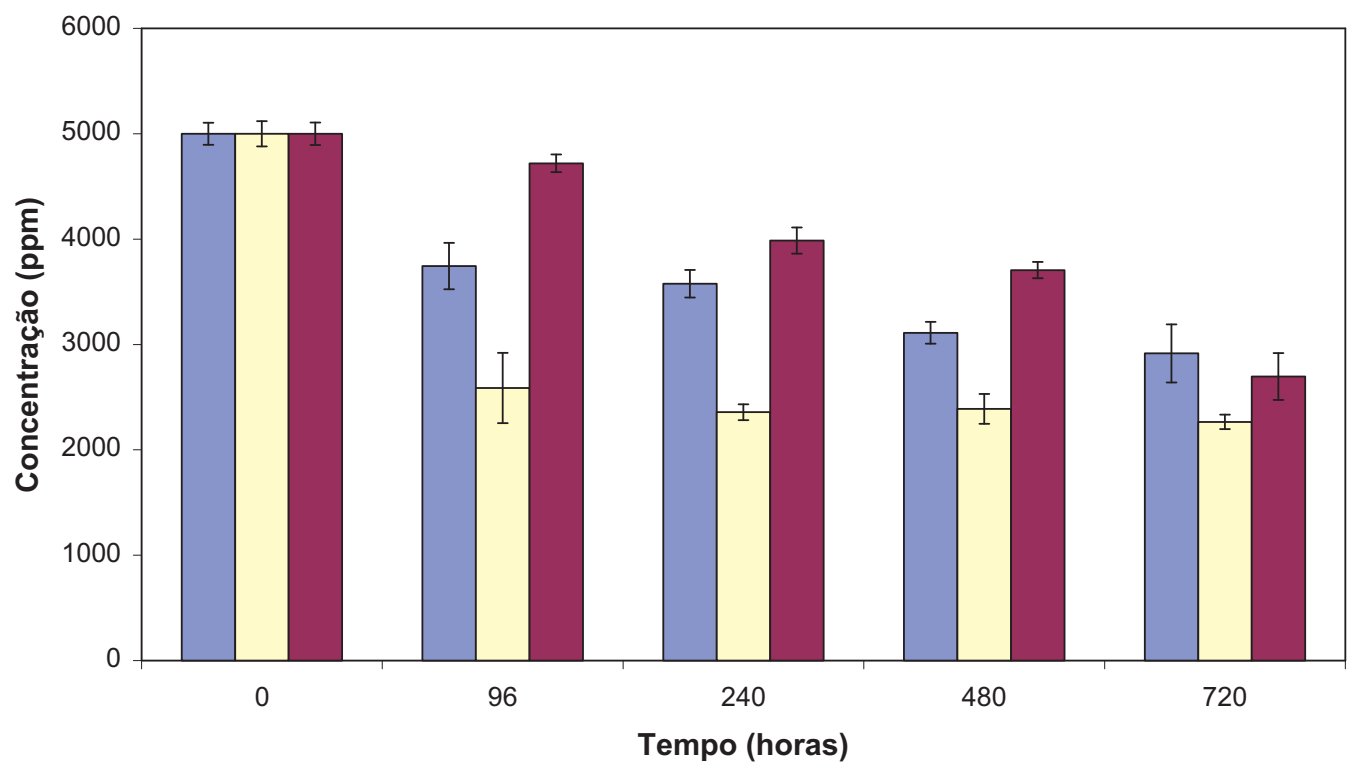

$\square$ Bia $\square$ Bia Lago $\square$ São Sebastião

FIGURA 29: Biodegradação de TBP por comunidades bacterianas cultivadas em meio mínimo $D\left({ }^{*} \alpha<0,05\right)$.

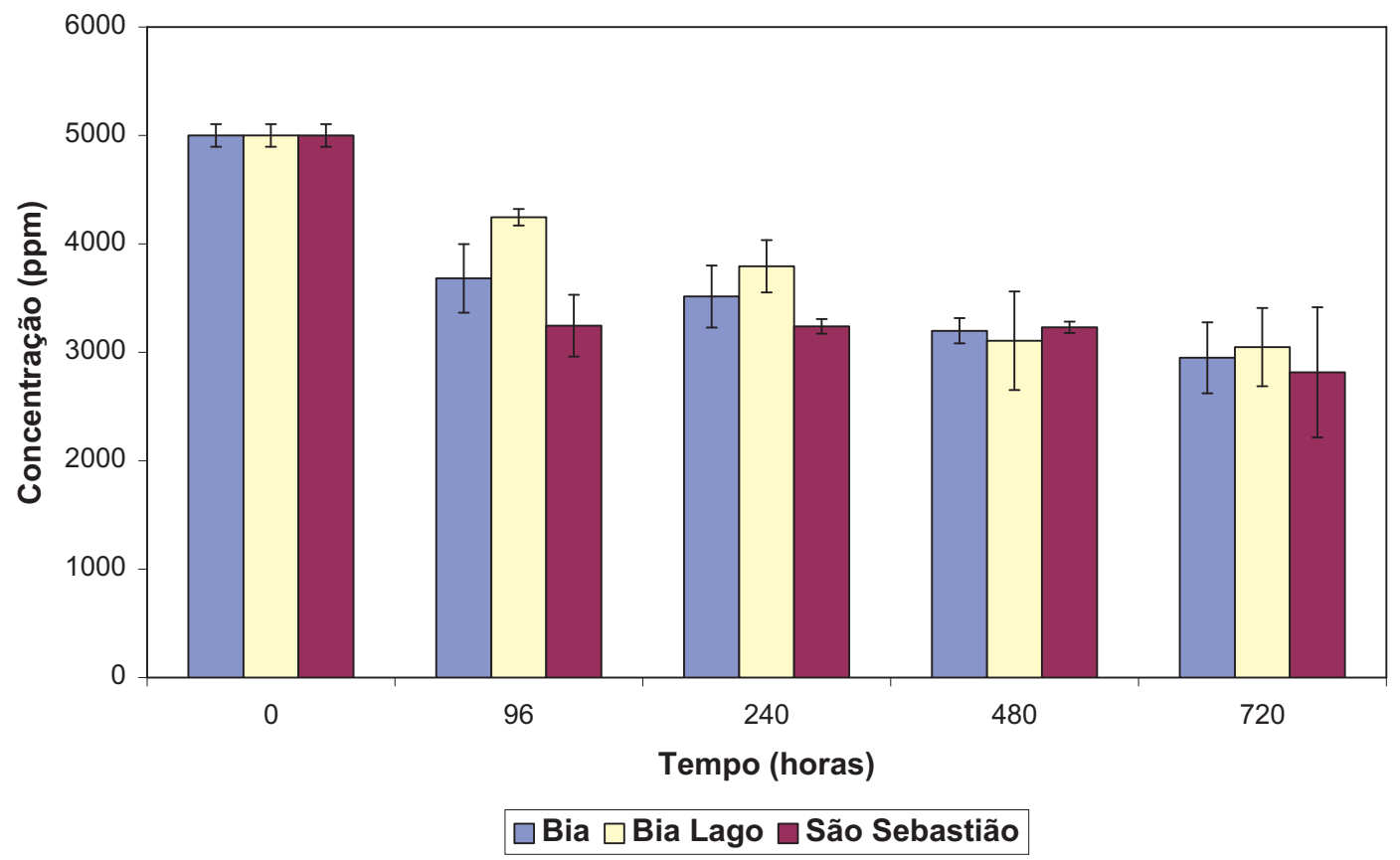

FIGURA 30: Biodegradação de TBP por diferentes comunidades microbianas em meio PAS ( $\left.{ }^{*} \alpha<0,05\right)$. 
TABELA 4: Degradação de TBP em função do tempo, pelos consórcios bacterianos Bia, Bia Lago e São Sebastião, cultivados em meio mínimo D e meio PAS.

\begin{tabular}{|c|c|c|c|c|c|}
\hline \multirow{2}{*}{$\begin{array}{l}\text { Meios } \\
\text { de } \\
\text { cultura }\end{array}$} & \multirow{2}{*}{$\begin{array}{l}\text { Consórcios } \\
\text { Bacterianos }\end{array}$} & \multicolumn{4}{|c|}{ Média \pm Desvio-padrão ppm (\% redução) } \\
\hline & & $96 h$ & 240h & 480h & 720h \\
\hline \multirow[t]{3}{*}{$\begin{array}{l}\text { Meio } \\
\text { mínimo D }\end{array}$} & Bia & $\begin{array}{c}3743,7 \pm 316,3 \\
(25,1 \%)\end{array}$ & $\begin{array}{c}3743,7 \pm 286,4 \\
(28,5 \%)\end{array}$ & $\begin{array}{c}3111,1 \pm 116,9 \\
(37,8 \%)\end{array}$ & $\begin{array}{c}2915,5 \pm 326,3 \\
(41,7 \%)\end{array}$ \\
\hline & Bia Lago & $\begin{array}{c}2587,6 \pm 75,6 \\
(48,3 \%)\end{array}$ & $\begin{array}{c}2357,7 \pm 241,6 \\
(52,9 \%)\end{array}$ & $\begin{array}{c}2387,9 \pm 455,0 \\
(52,2 \%)\end{array}$ & $\begin{array}{c}2265,2 \pm 360,2 \\
(54,7 \%)\end{array}$ \\
\hline & $\begin{array}{l}\text { São } \\
\text { Sebastião }\end{array}$ & $\begin{array}{c}4719,0 \pm 285,5 \\
(5,6 \%)\end{array}$ & $\begin{array}{c}3986,1 \pm 67,1 \\
(20,28 \%)\end{array}$ & $\begin{array}{c}3705,6 \pm 52,7 \\
(25,9 \%)\end{array}$ & $\begin{array}{c}2696,1 \pm 600,6 \\
(46,1 \%)\end{array}$ \\
\hline \multirow[t]{3}{*}{ Meio PAS } & Bia & $\begin{array}{c}3682,5 \pm 220,4 \\
(26,3 \%)\end{array}$ & $\begin{array}{c}3514,3 \pm 130,0 \\
(29,7 \%)\end{array}$ & $\begin{array}{c}3198,8 \pm 103,8 \\
(36,0 \%)\end{array}$ & $\begin{array}{c}2949,0 \pm 275,2 \\
(41,0 \%)\end{array}$ \\
\hline & Bia Lago & $\begin{array}{c}4246,1 \pm 333,1 \\
(15,1 \%)\end{array}$ & $\begin{array}{c}3794,22 \pm 75,0 \\
(24,1 \%)\end{array}$ & $\begin{array}{c}3106,6 \pm 141,3 \\
(37,9 \%)\end{array}$ & $\begin{array}{c}3048,1 \pm 68,2 \\
(39,0 \%)\end{array}$ \\
\hline & $\begin{array}{l}\text { São } \\
\text { Sebastião }\end{array}$ & $\begin{array}{c}3245,3 \pm 84,2 \\
(35,2 \%)\end{array}$ & $\begin{array}{c}3239,9 \pm 123,8 \\
(35,2 \%)\end{array}$ & $\begin{array}{c}3230,9 \pm 76,9 \\
(35,4 \%)\end{array}$ & $\begin{array}{c}2815,6 \pm 221,4 \\
(43,7 \%)\end{array}$ \\
\hline
\end{tabular}

Pelos resultados apresentados é possível notar que o composto com melhor taxa de degradação (apresentando em alguns casos de gradação superior a $90 \%$ ) foi o dodecano. Por outro lado, o composto com a menor taxa de degradação foi o acetato de etila, obtendo-se degradação máxima de 25,31\% pela comunidade São Sebastião em meio mínimo D.

Nas TAB. 2, 3 e 4 são apresentados todos os resultados obtidos. Pôde-se notar que a diminuição na fonte de fosfato no meio não interferiu na taxa de degradação dos compostos. E em relação à capacidade de degradação, a ordem crescente de preferência de degradação foi: o dodecano, o TBP e por último o acetato de etila. 


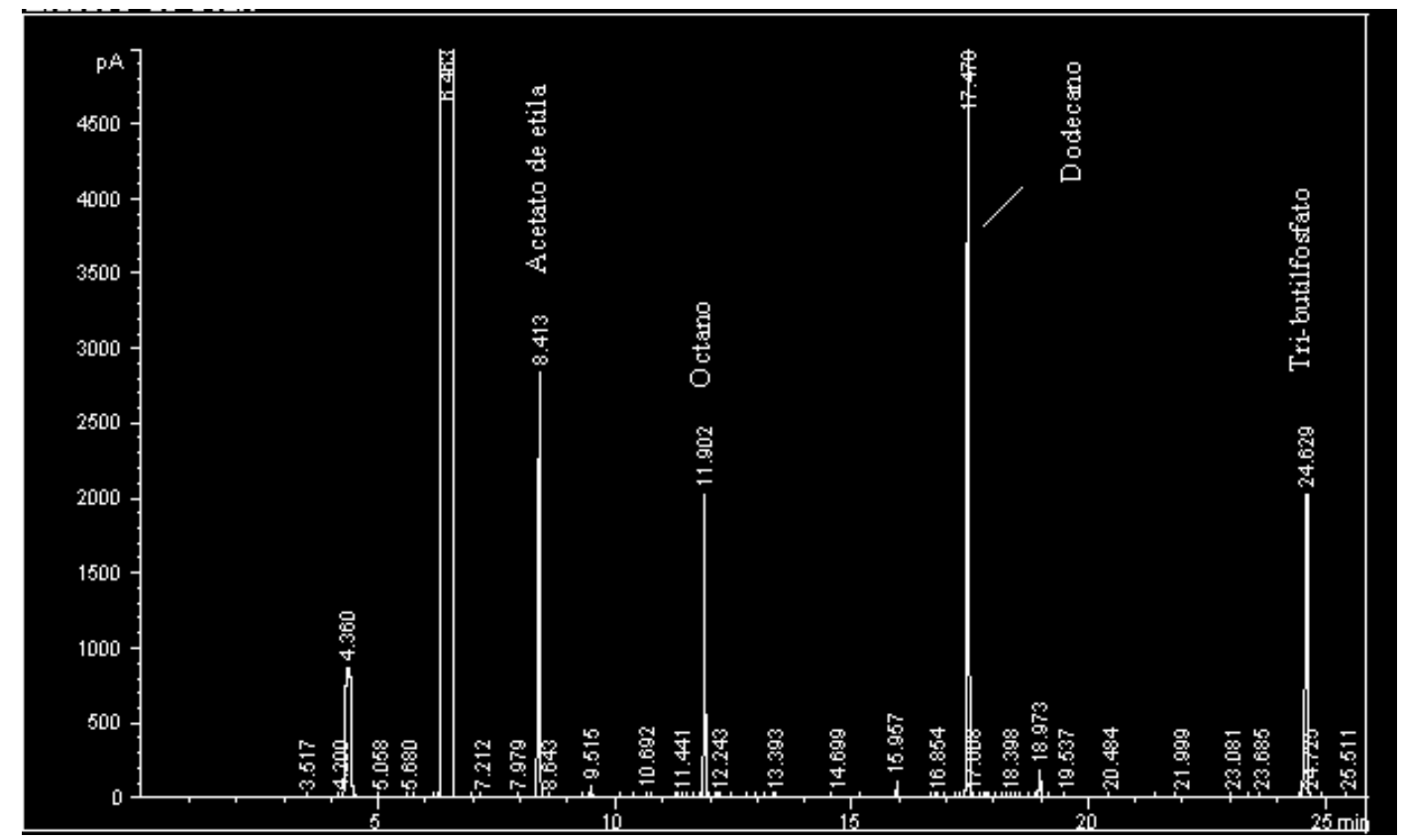

FIGURA 31: Cromatograma obtido para o padrão empregado no teste de degradação contendo acetado de etila, octano, dodecano e tri -butilfosfato na concentração de 5000ppm.

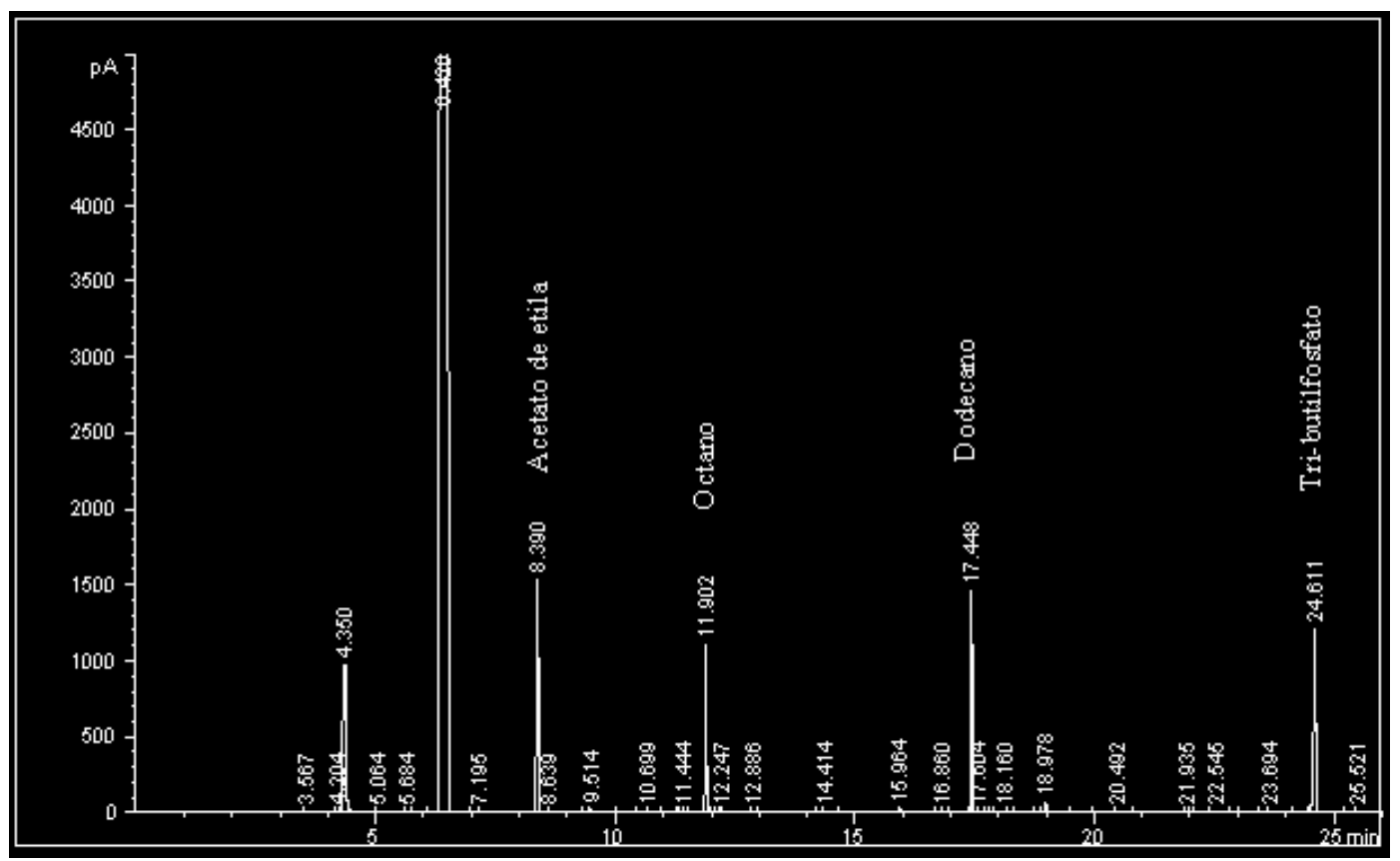

FIGURA 32: Cromatograma mostrando a degradação dos compostos estudados pela comunidade BIA. 


\subsection{Biodegradação dos RRLO}

\subsubsection{Concentração inibitória mínima (CIM) dos RRLO destilados}

As CIM dos rejeitos 80 e 85 destilados foram avaliadas para se determinar a concentração máxima das amostras no meio com a qual as comunidades bacterianas conseguem crescer. Os resultados obtidos nesta avaliação foram iguais aos obtidos na avaliação da CIM para os rejeitos in natura sendo as concentrações das amostras 80 e 85 destilado capazes de inibir o crescimento bacteriano, situando-se entre $32 \%$ e $50 \%$ para a comunidade bacteriana Bia e entre $16 \%$ e $32 \%$ para as comunidades bacterianas Bia Lago e São Sebastião.

\subsubsection{Ensaios de biodegradação dos RRLO 80 e 85 in natura e destilados.}

Os resultados obtidos nos experimentos de biodegradação dos RRLO, pelas comunidades bacterianas estão apresentados nas FIG. 33 à 38 . Os resultados foram comparados com a concentração inicial, aplicando -se o teste $t$ de Student, com nível de significância de 95\%.

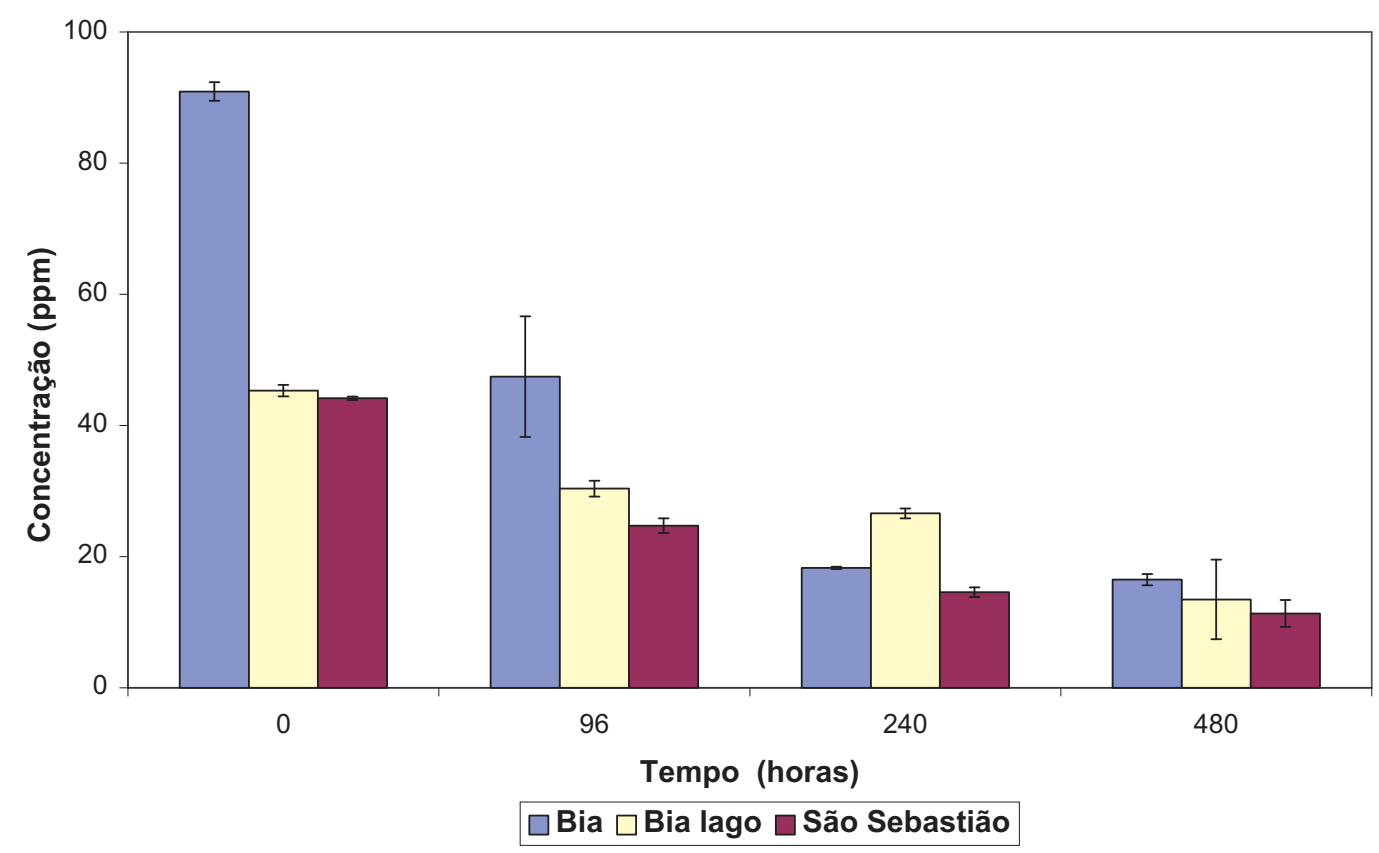

FIGURA 33: Variação da concentração de TBP em função d o tempo do RRLO 80 in natura, observada no ensaio de biodegradação com os consórcios bacterianos Bia, São Sebastião e Bia Lago. 
TABELA 5: Degradação de TBP presente no RRLO 80 in natura em função do tempo pelos consórcios bacterianos Bia, Bia Lago e São Sebastião cultivado em meio PAS.

\begin{tabular}{ccccc}
\hline \multirow{2}{*}{ Comunidades } & \multicolumn{4}{c}{ Média \pm Desvio-padrão ppm (\% redução) } \\
\cline { 2 - 5 } & $\mathbf{0 h}$ & $\mathbf{9 6 h}$ & $\mathbf{2 4 0 h}$ & $\mathbf{4 8 0 h}$ \\
\hline Bia & $90,9 \pm 1,4$ & $47,4 \pm 9,2$ & $18,3 \pm 0,2$ & $16,5 \pm 0,8$ \\
& $(0 \%)$ & $(47,8 \%)$ & $(79,9 \%)$ & $(81,9 \%)$ \\
Bia lago & $45,3 \pm 0,9$ & $30,4 \pm 1,2$ & $26,6 \pm 0,7$ & $13,5 \pm 6,1$ \\
& $(0 \%)$ & $(33,0 \%)$ & $(41,3 \%)$ & $(70,3 \%)$ \\
São Sebastião & $44,1 \pm 0,3$ & $24,7 \pm 1,1$ & $14,6 \pm 0,7$ & $11,3 \pm 2,0$ \\
& $(0 \%)$ & $(44,0 \%)$ & $(66,9 \%)$ & $(74,3 \%)$ \\
\hline
\end{tabular}

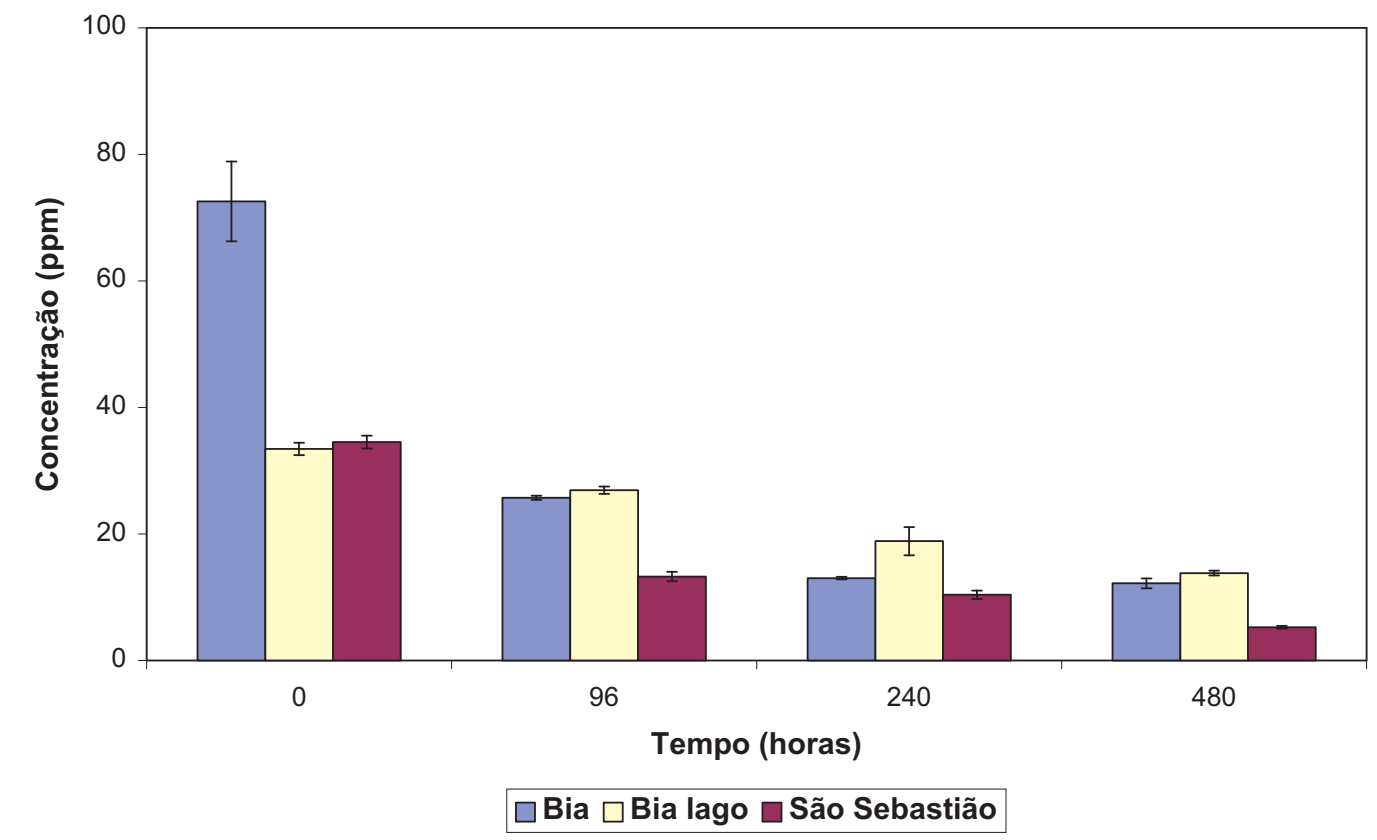

FIGURA 34: Variação do TBP em função do tempo do RRLO 85 in natura, observada no ensaio de biodegradação com os consórcios bacterianos Bia, São Sebastião e Bia Lago. 
TABELA 6: Degradação de TBP presente no RRLO 85 in natura em função do tempo pelos consórcios bacterianos Bia, Bia Lago e São Sebastião cultivado em meio PAS.

\begin{tabular}{ccccc}
\multirow{2}{*}{ Comunidades } & \multicolumn{4}{c}{ Média \pm Desvio-padrão ppm (\% redução) } \\
\cline { 2 - 5 } & $\mathbf{0 h}$ & $\mathbf{9 6 h}$ & $\mathbf{2 4 0 h}$ & $\mathbf{4 8 0 h}$ \\
\hline Bia & $72,6 \pm 6,3$ & $25,7 \pm 0,3$ & $13,0 \pm 0,2$ & $12,2 \pm 0,8$ \\
& $(0 \%)$ & $(64,6 \%)$ & $(82,1 \%)$ & $(83,2 \%)$ \\
& & & & \\
Bia lago & $33,4 \pm 1,0$ & $26,9 \pm 0,6$ & $18,9 \pm 2,2$ & $13,8 \pm 0,4$ \\
& $(0 \%)$ & $(24,1 \%)$ & $(39,2 \%)$ & $(80,5 \%)$ \\
São Sebastião & $34,5 \pm 1,0$ & $13,3 \pm 0,7$ & $10,4 \pm 0,6$ & $5,3 \pm 0,2$ \\
& $(0 \%)$ & $(61,5 \%)$ & $(69,9 \%)$ & $(84,8 \%)$ \\
\hline
\end{tabular}

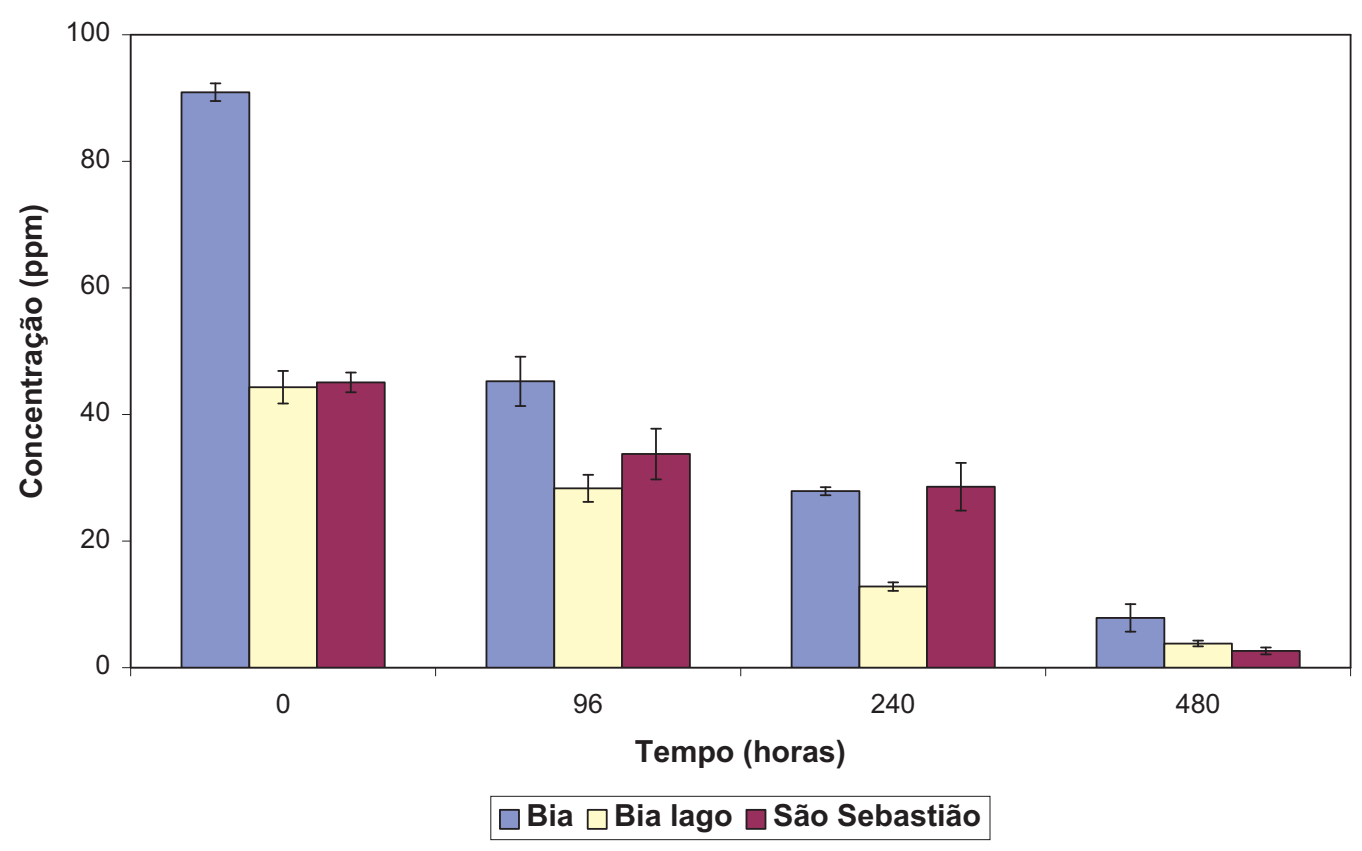

FIGURA 35: Variação da concentração de TBP em função do tempo do RRLO 80 destilado, observada no ensaio de biodegradação com os consórcios bacterianos Bia, São Sebastião e Bia Lago. 
TABELA 7: Degradação de TBP presente no RRLO 80 destilado em função do tempo pelos consórcios bacterianos Bia, Bia Lago e São Sebastião cultivado em meio PAS.

\begin{tabular}{ccccc}
\hline \multirow{2}{*}{ Comunidades } & \multicolumn{4}{c}{ Média \pm Desvio-padrão ppm (\% redução) } \\
\cline { 2 - 5 } & $\mathbf{0 h}$ & $\mathbf{9 6 h}$ & $\mathbf{2 4 0 h}$ & $\mathbf{4 8 0 h}$ \\
\cline { 2 - 5 } Bia & $90,9 \pm 1,4$ & $45,2 \pm 3,9$ & $27,9 \pm 0,6$ & $7,9 \pm 2,2$ \\
& $(0 \%)$ & $(50,2 \%)$ & $(69,3 \%)$ & $(91,3 \%)$ \\
Bia lago & $44,3 \pm 2,6$ & $28,3 \pm 2,1$ & $12,8 \pm 0,7$ & $3,8 \pm 0,4$ \\
& $(0 \%)$ & $(36,1 \%)$ & $(71,1 \%)$ & $(91,4 \%)$ \\
São Sebastião & $45,1 \pm 1,6$ & $33,8 \pm 4,0$ & $28,6 \pm 3,8$ & $2,6 \pm 0,5$ \\
& $(0 \%)$ & $(25,1 \%)$ & $(36,6 \%)$ & $(94,1 \%)$ \\
\hline
\end{tabular}

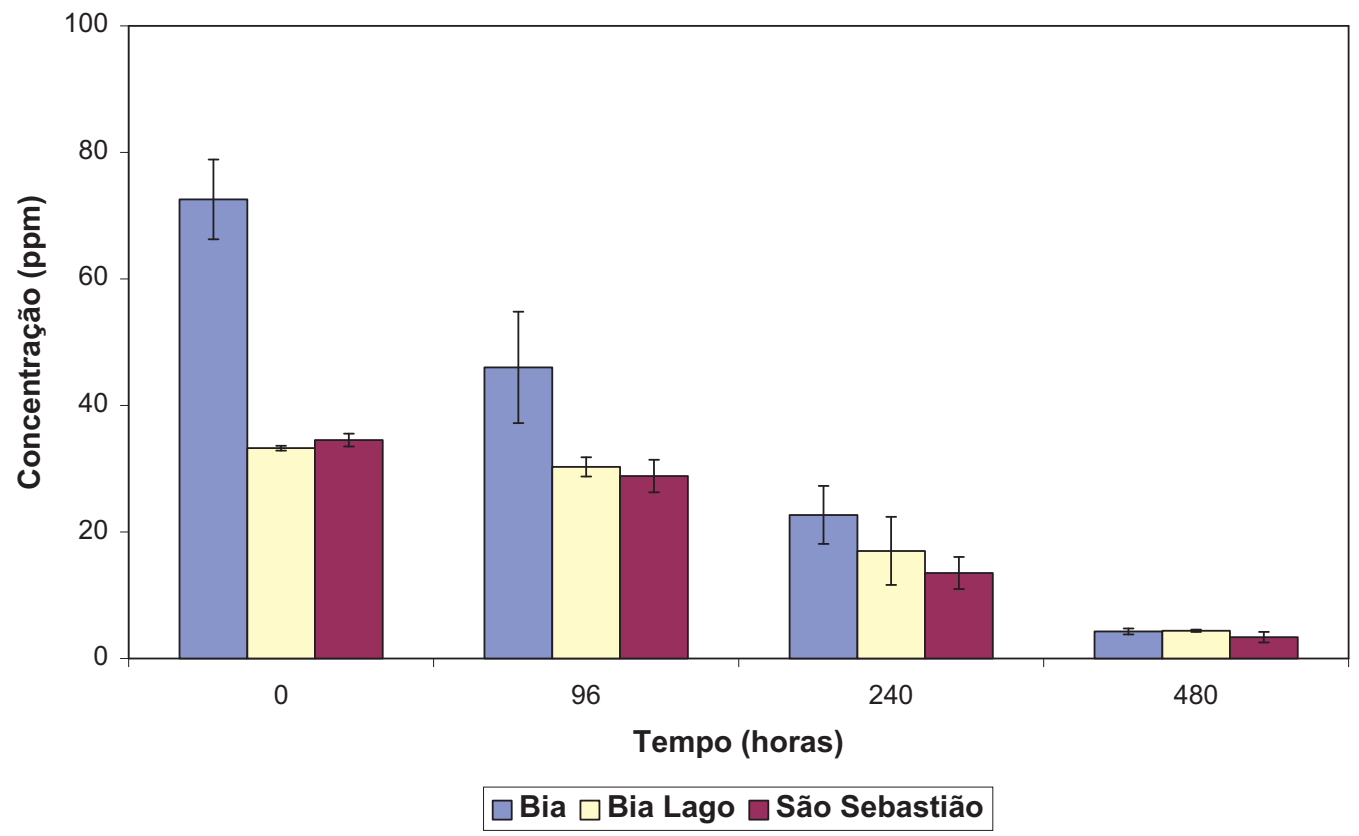

FIGURA 36: Variação da concentração de TBP em função do tempo do RRLO 85 destilado, observada no ensaio de biodegradação com os consórcios bacterianos Bia, São Sebastião e Bia Lago. 
TABELA 8: Degradação de TBP presente no RRLO 85 destilado em função do tempo pelos consórcios bacterianos Bia, Bia Lago e São Sebastião cultivado em meio PAS.

\begin{tabular}{ccccc}
\hline \multirow{2}{*}{ Comunidades } & \multicolumn{4}{c}{ Média \pm Desvio-padrão ppm (\% redução) } \\
\cline { 2 - 5 } & $\mathbf{O h}$ & $\mathbf{9 6 h}$ & $\mathbf{2 4 0 h}$ & $\mathbf{4 8 0 h}$ \\
\hline Bia & $72,6 \pm 1,4$ & $46,0 \pm 3,9$ & $22,7 \pm 0,6$ & $4,3 \pm 0,2$ \\
& $(0 \%)$ & $(36,6 \%)$ & $(68,7 \%)$ & $(94,1 \%)$ \\
Bia lago & $33,3 \pm 0,4$ & $30,3 \pm 1,5$ & $17,0 \pm 5,4$ & $4,4 \pm 0,2$ \\
& $(0 \%)$ & $(8,9 \%)$ & $(48,9 \%)$ & $(86,8 \%)$ \\
São Sebastião & $34,5 \pm 1,0$ & $28,8 \pm 0,7$ & $13,5 \pm 0,6$ & $3,4 \pm 0,2$ \\
& $(0 \%)$ & $(16,4 \%)$ & $(60,9 \%)$ & $(90,3 \%)$ \\
\hline
\end{tabular}

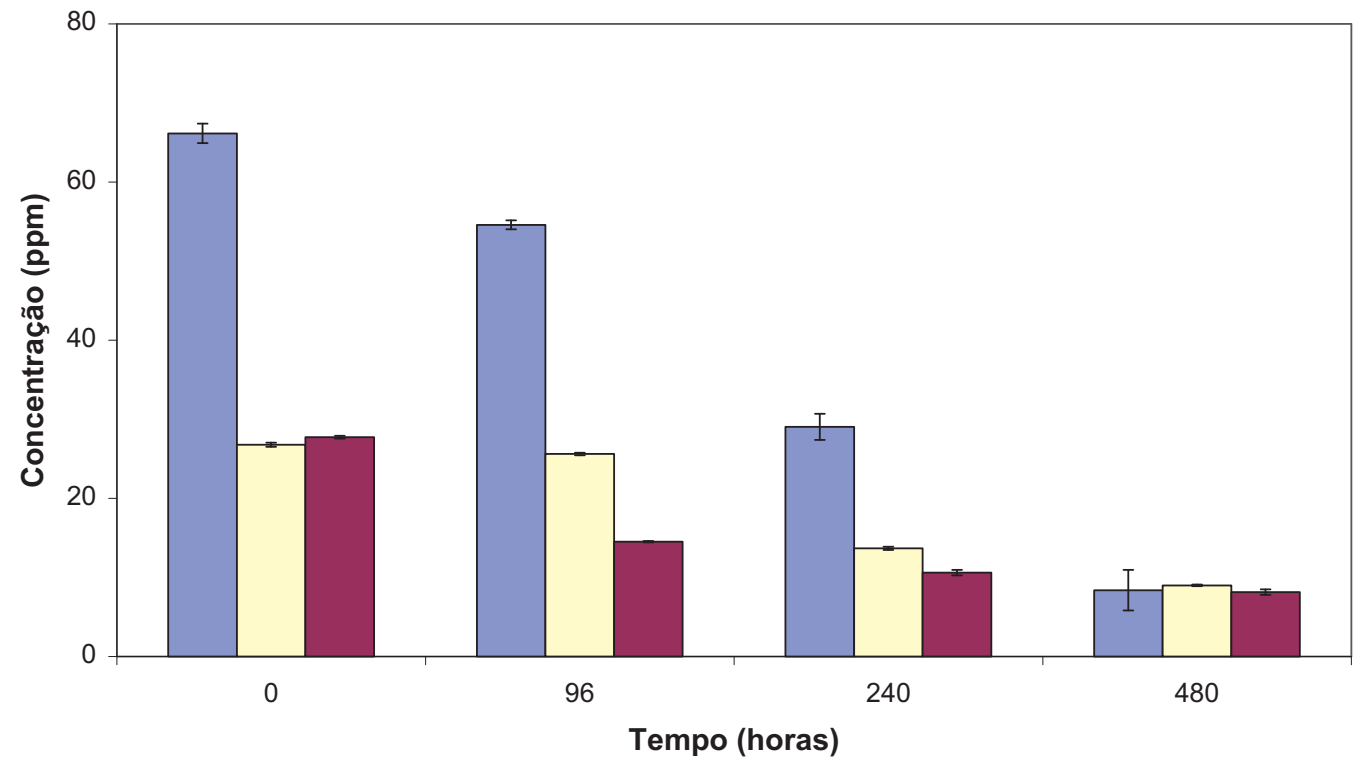

$\square$ Bia $\square$ Bia lago $\square$ São Sebastião

FIGURA 37: Variação da concentração de acetato de etila em função do tempo do RRLO 80 in natura, observada no ensaio de biodegradação com os consórcios bacterianos Bia, São Sebastião e Bia Lago. 
TABELA 9: Degradação de acetato de etila em RRLO 80 in natura em função do tempo pelos consórcios bacterianos Bia, Bia Lago e São Sebastião cultivados em meio PAS.

\begin{tabular}{ccccc}
\hline \multirow{2}{*}{$\begin{array}{c}\text { Comunidades } \\
\text { bacterianas }\end{array}$} & \multicolumn{4}{c}{ Média \pm Desvio-padrão ppm (\% redução) } \\
\cline { 2 - 5 } & $\mathbf{0 h}$ & $\mathbf{9 6 h}$ & $\mathbf{2 4 0 h}$ & $\mathbf{4 8 0 h}$ \\
\hline Bia & $66,2 \pm 1,2$ & $54,6 \pm 0,6$ & $29,0 \pm 1,6$ & $8,4 \pm 2,6$ \\
& $(0 \%)$ & $(17,5 \%)$ & $(56,1 \%)$ & $(87,3 \%)$ \\
Bia Lago & $26,8 \pm 0,3$ & $25,6 \pm 0,1$ & $13,7 \pm 0,2$ & $9,0 \pm 0,1$ \\
& $(0 \%)$ & $(4,4 \%)$ & $(48,9 \%)$ & $(66,4 \%)$ \\
São Sebastião & $27,7 \pm 0,2$ & $14,5 \pm 0,1$ & $10,6 \pm 0,3$ & $8,1 \pm 0,3$ \\
& $(0 \%)$ & $(47,7 \%)$ & $(61,8 \%)$ & $(70,6 \%)$ \\
\hline
\end{tabular}

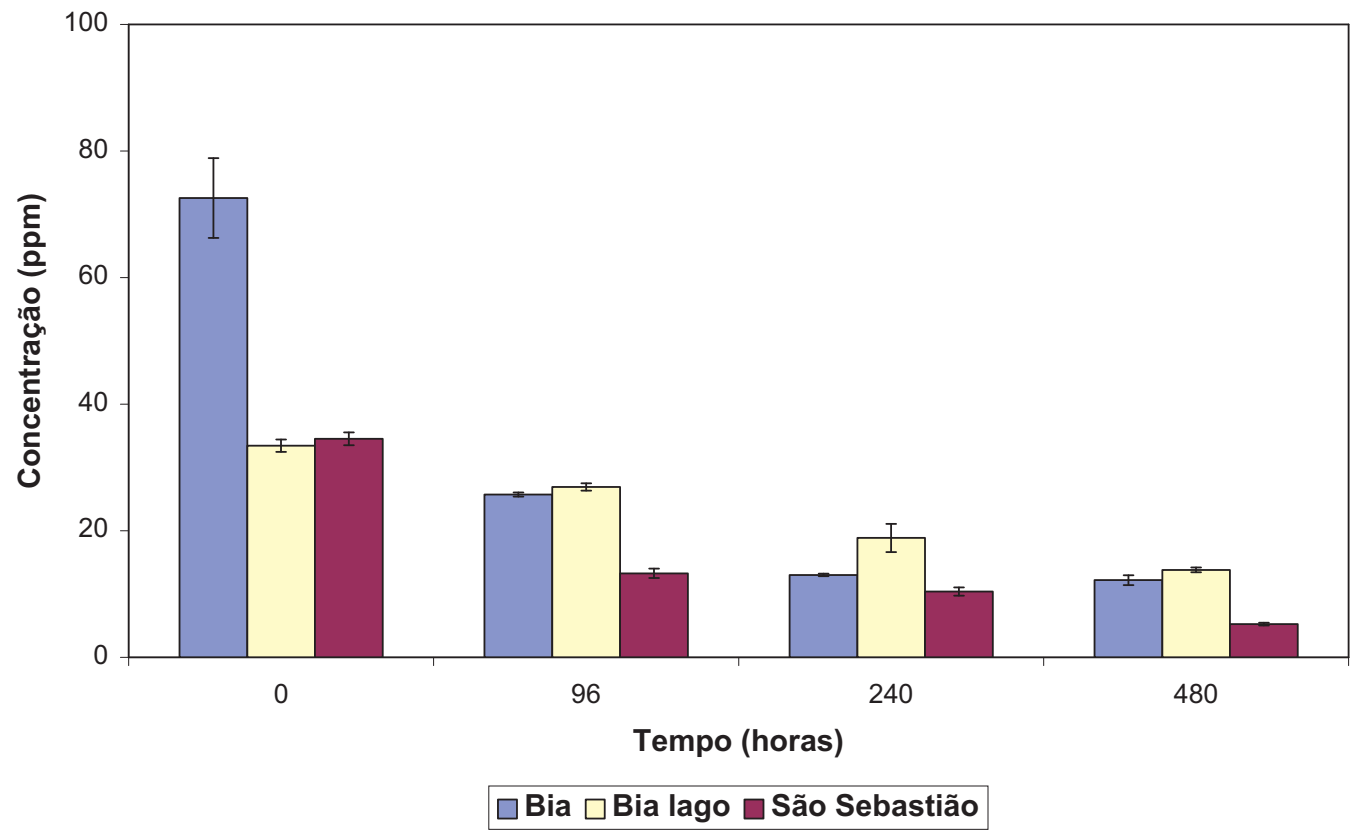

FIGURA 38: Variação da concentração de acetato de etila em função do tempo do RRLO 85 in natura, observada no ensaio de biodegradação com os consórcios bacterianos Bia, São Sebastião e Bia Lago. 
TABELA 10: Degradação de acetato de etil a em RRLO 85 in natura em função do tempo pelos consórcios bacterianos Bia, Bia lago e São Sebastião cultivados em meio PAS.

\begin{tabular}{ccccc}
\hline \multirow{2}{*}{$\begin{array}{c}\text { Comunidades } \\
\text { bacterianas }\end{array}$} & \multicolumn{4}{c}{ Média \pm Desvio-padrão ppm (\% redução) } \\
\cline { 2 - 5 } & $\mathbf{0 h}$ & $\mathbf{9 6 h}$ & $\mathbf{2 4 0 h}$ & $\mathbf{4 8 0 h}$ \\
\hline Bia & $61,7 \pm 1,4$ & $25,2 \pm 1,6$ & $18,1 \pm 3,9$ & $13,7 \pm 2,5$ \\
& $(0 \%)$ & $(59,2 \%)$ & $(70,6 \%)$ & $(77,8 \%)$ \\
Bia Lago & $29,5 \pm 3,2$ & $25,3 \pm 1,4$ & $13,1 \pm 2,6$ & $9,3 \pm 1,6$ \\
& $(0 \%)$ & $(14,1 \%)$ & $(55,4 \%)$ & $(68,6 \%)$ \\
São Sebastião & $29,8 \pm 3,1$ & $16,3 \pm 0,3$ & $9,1 \pm 0,1$ & $7,1 \pm 0,4$ \\
& $(0 \%)$ & $(45,3 \%)$ & $(69,4 \%)$ & $(76,2 \%)$ \\
\hline
\end{tabular}

Com os resultados apresentados nas FIG. 33 à 38 e nas TAB. de 5 à 10 pode-se verificar que concentração do TBP no rejeito in natura e destilado e do acetato de etila no rejeito in natura diminuiu em função do tempo, após o tratamento com os consórcios bacterianos. Este comportamento está de acordo com os resultados obtidos por THOMAS et al (1997a), THOMAS et al (1997b) e THOMAS \& MACASKIE (1997b) e DORONINA (2006).

Foi observada uma maior redução da concentração dos compostos orgânicos presentes nos rejeitos in natura e destilados quando comparados com a degradação dos compostos orgânicos da segunda etapa. Este comportamento poderia ser explicado pela presença de sais nos rejeitos que favoreceriam o crescimento bacteriano. Apesar de haverem estudos que mostraram uma inibição da degradação de TBP na presença de metais, como o do THOMAS \& MACASKIE (1998), existem outros que corroboram, como os do CAPONE et al. (1983), LIN (1993) e KUO \& GENTHENER (1996), que reportaram um aumento da atividade dos microrganismos na presença de diversos metais, entre eles $\mathrm{Cu}$, $\mathrm{Zn}, \mathrm{Cr}, \mathrm{Cd}, \mathrm{Pb}$ e $\mathrm{Ni}$.

Pode-se observar nas TAB. de 5 à 10 que o TBP sofreu degradação mais rápida que o acetato de etila nos rejeitos in natura com todas as comunidades bacterianas, exceto pela São Sebastião no rejeito 80 . Com as comunidades Bia e Bia Lago foi verificada uma diminuição da concentração de TBP, em 96 horas, de $47,8 \%$ e $33,0 \%$, respectivamente. Os percentuais de degradação do acetato de etila foram bem inferiores, em torno de $17 \%$ e $4 \%$. Com a comunidade São 
Sebastião a degradação do acetato de etila foi ligeiramente superior. Com o rejeito 85 , também foi verificada diminuição mais rápida da concentração do TBP, sem exceções. Neste caso, porém, houve uma degradação maior, de 64,6\%, $24,1 \%$ e 61,5\%, para Bia, Bia Lago e São Sebastião, respectivamente. Em 480h, a concentração do TBP foi inferior a do acetato de etila, exceto no rejeito $80 \mathrm{com}$ a comunidade Bia, que foi 6 pontos percentuais superior. Em todos os casos, a degradação foi superior a 70\%. A maior degradação do TBP em relação ao acetato de etila poderia ser justificada pela possibilidade do TBP ser utilizado pelos microrganismos como fonte de fosfato, além de carbono ( THOMAS \& MACASKIE, 1998).

Comparando-se a degradação do TBP nos rejeitos in natura e destilados, verifica-se uma maior diminuição da concentração no rejeito destilado. Esses resultados poderiam ser explicados pela presença de outros compostos orgânicos no rejeito in natura que também poderiam servir como fonte de carbono, interferindo na degradação do TBP. Por exemplo, a piridina e o hexano, compostos que possuem sua biodegradação já descrita por MUDLIAR (2008) e Lee \& Cho (2008). No entanto, apesar da destilação prévia ter melhorado o processo de degradação e ainda, reduzir o volume do rejeito, sua implementação deve ser bem avaliada levando-se em consideração o volume de rejeito a ser tratado, a geração de rejeitos secundários, riscos de manipulação de soluções radioativas.

\subsection{Considerações finais}

Neste trabalho foram realizados ensaios para biodegradar compostos orgânicos presentes em rejeitos radioativos líquidos. Foram estudados os dois rejeitos que continham as maiores concentrações de radionuclídeos. A composição da fase orgânica foi determinada por cromatografia gasosa e os resultados mostraram que os maiores constituintes são o TBP e o acetato de etila.

No ensaio de degradação, os parâmetros avaliados foram o emprego de diferentes comunidades bacterianas (Bia, Bia lago e São Sebastião) coletadas de áreas impactadas, o tempo de contato e a presença/ausência de compostos orgânicos voláteis. 
Foi observado um aumento da degradação em função ao tempo verificando-se uma melhoria no processo de degradação com a destilação pr évia. As comunidades bacterianas que mais degradaram o TBP e acetato de etila foram Bia e São Sebastião. No entanto, para uma aplicação em uma escala maior, a comunidade Bia seria a mais indicada, pois suportaria uma quantidade maior de rejeito de acordo com o observado nos ensaios de CIM. 


\section{CONCLUSÕES}

A partir dos resultados obtidos nos experimentos $p$ ode-se concluir que:

1. A comunidade bacteriana Bia apresentou maior capacidade de crescimento nos RRLO estudados.

2. Todas as comunidades estudadas degradaram, de modo eficiente quando comparado com os resultados descritos na literatura, o TBP e o acetato de etila. O melhor desempenho foi da comunidade Bia.

3. A destilação prévia dos RRLO melhorou o processo de biodegradação.

4. A biodegradação é um método viável e eficiente para o tratamento dos rejeitos líquidos orgânicos provenientes das atividades de reprocessamento. 


\section{TRABALHOS FUTUROS}

A seguir são apresentadas algumas sugestões para trabalhos futuros que complementam este trabalho:

- Avaliação da eficiência da biodegradação dos rejeitos radioativos líquidos orgânicos provenientes do reprocessamento em esc ala piloto;

- Estudo da compatibilidade do rejeito biodegradado com diferentes matrizes de imobilização como cimento e betume;

- Avaliação da viabilidade econômica da aplicação do processo de biodegradação para tratamento dos rejeitos líquidos orgânicos em grande escala;

- Identificação das bactérias presentes nas comunidades microbianas utilizadas no processo de biodegradação . 


\section{REFERÊNCIAS}

AMARAL, E. C. S.; AZEVEDO, H. L. P; MENDONÇA, A. H. Pre-operational environmental survey at the uranium mine and mill site, Poços de Caldas, Minas Gerais. The Science Of The Total Environment, Brazil, v. 48, n. 4-5, p.257-266, 1985.

AMPHLETT, C.B. Treatment and disposal of radioactive wastes . International Series of Monographs on Nuclear Report Series. Division V, v.2, Pergamon Press, London, 1961.

BERNE, C.; MONTJARRET, B.; GUOUNTTI, Y.; GARCIA, D.; Tributyl phosphate degradation by Serratia odorifera. Biotec. Letters. v. 26, p.681-686, 2004.

BITTON, G. Wastewater microbiology. Willey-liss, New. York, 2005.

BRUICE, P.Y. Química Orgânica. Pearson Prentice Hall, São Paulo, Ed 4, 2006.

CAPONE, D. G.; REESE D.D.; KIENE, R.P. Effects of metais on methanogenesis, sulfate reduction, carbon dioxide evolition, and microbial biomass in anoxic salt marsh sediments. Appl. Environ. Microbial ., v 45, p. 1586-1591, 1983.

COMISSÃO NACIONAL DE ENERGIA NUCLEAR. Gerência de rejeitos radioativos em instalações radioativas . Rio de Janeiro: CNEN-NE-6.05, CNEN, 1985.

COMISSÃO NACIONAL DE ENERGIA NUCLEAR. Critérios de Aceitação para Deposição de Rejeitos Radioativos de Baixo e Médio Níveis de Radiação . Rio de Janeiro: CNEN-NN 6.09, CNEN, 2002.

CRAVO JÚNIOR, W. B. Biodegradação de querosen e de aviação (QAV) por culturas mistas e por Pseudomonas aeruginosa. 1998. Dissertação (Mestrado)-Escola de Química da Universidade Federal do Rio de Janeiro. Rio de Janeiro.

DEGUITRE J.; STINGRE, M. Process and apparatus for treating oils and solvents contaminated by radioactive substances. USA Pat. 005948259. 1999.

DELLAMANO, J. C. Laboratório de Rejeito Radioativo. Unidade de armazenamento e tratamento de rejeitos radioativos líquidos e sólidos úmidos. IPEN/CNEN-SP, Comunicação pessoal, 2005.

DOBLE M. AND KUMAR A. Biotreatment of Industrial Effluents . Elsevier. 2005

DORONINA, N. V.; NAZAROV, N. M.; EZHOV, V. A.. Biodegradation of methyl and ethyl acetates by immobilized Pseudomonas esterophilus cells. Appl. Biochem. Microb., v. 42, n. 1, p.45-47, 2006. 
DOUGLAS, G.S.; MCCARTHY, K.J.; DAHLEN, D.T.; SEAVEY, J.A.; STEINHAUER, W.G.; PRINCE R.C; ELMENDORF, D.L. The use of hydrocarbon analyses for environmental assessment and remediation. In P.T. Kostecki and E. J. Calabrese, eds., Contaminated Soils: Die sel Fuel Contamination, Lewis Publishers, an Imprint of CRC Press, Boca Raton, FL, pp. 1 21. 1992.

EATON, A. D.; CLESCERI, L.S.; GREENBERG, A. E. Standard methods for the examination of water and wastewater. Washington: American Public Health Association, American Water Works Association and Water Environment Federation. ed 19., 1995.

ENDO, L.S. Tratamento de rejeitos radioativos compostos por solventes orgânicos: sistema TBP/DODECANO. Instituto de Pesquisas Energéticas e Nucleares, São Paulo, Brasil, 1991.

FABIANO B. ; PASTORINO R.; FERRANDO M.; Distillation of radioactive liquid organic wastes for subsequent wet oxidation. J. Haz. Mat. v. 57, pp. 105-125. 1998

FERNANDES, H.M.; VEIGA, L. H. S.; FRANKLIN, M. R.; PRADO, V. C. S.; TADDEI, J. F. Environmental impact assessment of uranium mining and milling facilities: A study case at the Pocos de Caldas uranium mining and milling site, Brazil. J. Geoch. Expl.,v.52(1-2), pp 161-173, 1995.

FORBICINI, C. A. L. G. Procedimentos eletroquímicos no tratamento do combustível nuclear irradiado. 1994. Tese (Doutorado). Instituto de Pesquisas Energéticas e Nucleares. São Paulo.

GARCIA, D. A. Process for the degradation of tributyl phosphate . WO2004/101449. 2003.

GONÇALVES, C. R. Remoção de manganês e recuperação de urânio presentes em águas ácidas de mina. 2006. Dissertação (mestrado)- Centro de Desenvolvimento da Tecnologia Nuclear. Belo Horizonte minas gerais

HIROMOTO, G.; DELLAMANO, J.C.; MARUMO, J.T.; ENDO, L.S.; VICENTE, R.; HIRAYAMA, T. Introdução à gerência de rejeitos radioativos, Instituto de Pesquisas Energéticas e Nucleares -Departamento de Rejeitos Radioativos, São Paulo, 1999.

INTERNATIONAL ATOMIC ENERGY AGENCY . Predisposal management of organic radioactive waste, Vienna, 2004.

INTERNATIONAL ATOMIC ENERGY AGENCY, Radioactive waste management glossary IAEA - TECDOC-447, 2. ed. Vienna, 1988.

INTERNATIONAL ATOMIC ENERGY AGENCY. Handling and storage of conditioned high-level wastes. TECDOC-229, Vienna, 1983 
INTERNATIONAL ATOMIC ENERGY AGENCY. Treatment of low-and intermediate-level liquid radioactive wastes. TECDOC-236, Vienna, 1984

IRWIN, R.J.; VANMOUWERIK M.; STEVENS L.; SEESE M.D ; BASHAM W.. Environmental Contaminants Encyclopedia. National Park Service, Water Resources Division, Fort Collins, Colorado. Distributed within the Federal Government. 1997.

ISHIGURO, YUJI. A Energia Nuclear para o Brasil. Makron Books, 2001.

ISHIKAWA, S.; TAKETOMI, M.B.; SHINOHARA, R. Determination of trialkyl and triaryl phosphates in environmental samples. WATER RES. 19: 119-125. 1985

Japan Chemical Industry Ecology-Toxicology \& Information Center (JETOC). INITIAL ASSESSMENT PROFILE: Tributyl phosphate. Disponível em : http://www.jetoc.or.jp/HP_SIDS/pdffiles/126-73-8.pdf acessado em 24 de agosto de 2008.

JT BAKER. Material Safety Data Sheet: Ethyl Acetate. Disponível em: http://www.jtbaker.com/msds/englishhtml/e2850.htm acessado em 24 de agosto de 2008.

KUO C. W.; GENTHNER, B. R. S. Effect of added heavy metal ions on biotranformation and biodegradation of 2 -chlorophenol and 3-chlorobenzoate in anaerobic bacterial consortia. Appl. Environ. Microbiol., v.62, p. 2317-2323, 1996.

LEE E.H.; CHO K.S. Characterization of cyclohexane and hexane degradation by Rhodococcus sp. EC1. Chemosphere. v .71, p. 1738-1744, 2008.

LIMA,T.M.S. Produção de biossurfactantes visando ao tratamento de borra oleosa. Dissertação (Mestrado). Universidade Federal de Viçosa. Minas Gerais. 2003.

LIN C.Y. Effect of heavy metais on acidogenesis in anaerobic digestion, Water Res., v. 27, p. 147-152, 1993.

MACASKIE, LYNNE E. The Application of Biotechnology to the Treatment of Wastes Produced from the Nuclear Fuel Cycle: Biodegradation and Bioaccumulation as a Means of Treating Radionuclide-Containing Streams. Crit. Rev. Biotech., v. 11, n. 1, p. 41-112, 1991

MATSUDA, H. T., ARAUJO, B. F., ARAUJO, J. A. Analilytical process controlo f the celeste R\&D Installation OF IPEN -CNEN/SP. J. Radioanal. Nucl. Chem., Letters. v. 6, 453-463, 1995.

MEDEIROS, P. M.; BÍCEGO, M. C. Investigation of natural and anthropogenic hydrocarbon inputs in sediments using geochemical mar kers. II. São Sebastião, SP-Brazil. Marine Pollution Bulletin, v. 49, p. 11-12, 2004 
MESQUITA, C. H.. Soluções Cintiladoras- Apontamentos relativos a física instrumentação metodologia e aplicações praticas. INFORMACAO IPEN, v. 2, p. 1-65, 1980.

MUDLIAR, S. N.; PADOLEY, K. V., MATT, P; SURESHKUMAR, M.; LOKHANDE, S. K.; PANDEY, R. A.; VAIDYA, A. N. Py ridine biodegradation in a novel rotating rope bioreactor. Biores. Tech. v. 99, p. 1044-1051. 2008

NAKAMURA, A. International programme on chemical safety - environmental health critiria 112 - Tri-n-butyl Phosphate. World Health Organization. Geneva, Switzerland. 1991.

NASCIMENTO, M. R. L. Remoção e recuperação de urânio de águas ácidas de mina por resina de troca iônica. 1998. Dissertação (Mestrado) Universidade Federal de São Carlos. São Carlos.

NATIONAL COMITTEE FOR CLINICAL LABORATORY STANDAR DS. Methods for dilution antimicrobial susceptibility tests for bacteria that grow aerobically. Approved standard M7-A5. NCCLS. 2003.

OAK RIDGE NATIONAL LABORATORY. Installation restoration program toxicology guide. Five Volumes. Produced by Oak Ridge Nat ional Laboratory (87-TH-0002) for the Hazard Assessment Branch, Toxic Hazards Division, Harry G. Armstrong Aerospace Medical Research Laboratory (AAMRL), Wright Patterson Air Force Base, OH. Available from NTIS, Springfield, VA. 1989.

OLIVERA N.L.; ESTEVES J.L.; COMMENDATORE M.G. Alkane biodegradation by a microbial community from contaminated sediments in Patagonia, Argentina. Int Biodet Biodeg., v 40, n. 1, p. 75-79, 1997.

POFFO, I.R.F.; NAKASAKI, A.; EYSINK, G.G.J.; HEITZMANN, S.R. ; CANTÃO, R.F. ; MIDAGLIA, C.L.V.; CAETANO, N.A. ; SERPA, R. R. ; AVENTURATO, H.; POMPÉIA, S.L. Dinâmica dos vazamentos de óleo no Canal de Sã o Sebastião. São Paulo: CETESB, 2V. 1996.

RHODIA. Ficha de segurança: Acetato de Etila. Disponível em: www.rhodiapi.com.br/conteudo/produtos/PDF/acetatodeetila_por.p df acessado em 24 de agosto de 2008.

RODRIGUES, D. F. Caracterização polifásica da biodiversidade de isolados degradadores de poluentes xenobióticos na baixada santista. Dissertação (Mestrado)-Universidade de São Paulo. São Paulo. 2002.

SCHWINKENDORF, W. E., J. MCFEE, M. DEVARAKONDA, L. L. NENNINGER, F. S. FADULLON, T. L. DONALDSON, AND K. DICKERSON. Alternatives to Incineration Technical Area Status Report. DOE/MWIP-26. Mixed Waste Integrated Program, U. S. Department of Energy, office of Technolog y Development, Washington, DC. 1995. 
SINGH, B. K.; WALKER, A. Microbial degradation of organophosphorus compounds. FEMS Microb. Rev. vol. 30, no3, pp. 428-471, 2006.

STRINGFELLOW W. T.; KOMADA T.; CHANG L. Y., Biological treatment of concentrated hazardous, toxic, and radionuclide mixed wastes without dilution. Lawrence Berkeley National Laboratory. Paper LBNL -55928, 2004

SUGIMOTO, L. Estudo avalia impacto econômico de derrame de petróleo em Ilhabela. Jornal da Unicamp. Ed 232. 2003.

THOMAS R. A., MACASKIE L.E. The effect of growth conditions on the biodegradation of tributyl phosphate and potential for the remediation of acid mine drainage waters by a naturallyoccurring mixed microbial culture. Appl. Microbiol. Biotechnol. v.49, p. 202-209. 1998.

THOMAS R.A. P.; GREATED A.; LAWLOR K.; BAILEY M.; MACASKIE L.E. Stabilisation of tributyl phosphate-biodegradative ability of natural-occuring Pseudomonas using ampicillin. Biotechnol Tech. V.11, p. 781-785. 1997a

THOMAS R.A.P.; MORBY A.P.; MACASKIE L.E. The biodegradation of tributyl phosphate by naturally occurring. FEMS Microb. Letters. vol. 155, no2, p. 155159. $1997 b$.

THOMAS R.A.P.; MACASKIE L. E. Biodegradation of tributyl phosphate by natural occuring microbial isolates and coupling to the removal of uranium from aqueous solution. Environ. Sci. Biotechnol. v.30: p2371-2375, 1996.

THOR. database Pomona 89, MedChem Software. Daylight Chemical Information Systems, Claremont, CA 91711. 1989

UNIVERSITY OF MINNESOTA BIOCATALYSIS/BIODEGRADATION DATABASE. (UM-BBD). Pathway Map Ethyl Acetate. Disponível em: http://umbbd.msi.umn.edu/servlets/dpage?\&ptype=p\&reaclD=r0170\&max_rows $=0$ acessado em 24 de agosto de 2008.

UNITED NATIONS ENVIRONMENT PROGRAMME (UNEP). TRIBUTYL PHOSPHATE CAS N: 126-73-8, UNEP PUBLICATIONS Paris, France . 2001.

VANDERBERG, L. A.; FOREMAN T. M.; ATTREP M.; BRAINARD J. R., SAUER $\mathrm{N}$. Treatment of heterogeneous mixed wastes: Enzyme degradation of cellulosic materials contaminated with hazardous organ ics and toxic and radioactive metals. Environ. Sci. Technol. v33(8). p. 1256-1262. 1999

WILLS, D.; STEPHEN, S.; BRYAN, E. University of Minnesota. Pathway Map Octane. Disponível em http://umbbd.msi.umn.edu/oct/oct_map.html acessado em 24 de agosto de 2008. 